\title{
الأصول العقدية عند المرجئة وعلاقتها بالأخلاق (عرض ومناقشة)
}

\author{
كئية إعداد الدكتور

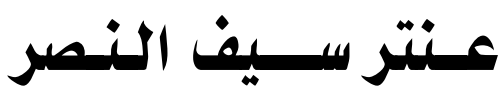 \\ الملدرس بقسم العقيلة و الثلسفة
}

بِّ كلية أصول الدين والدعوة بأسيوط - جامعة الأزهر

rq^ 
الأصول العقدية عند المرجئة وعلاقتها بالأخلاق (عرض ومناقشة)

عنتر سيف النصر

قسم العقيدة والفلسفة - في كلية أصول الدين والدعوة - جامعة الأزهر -

بأسيوط - مصر

البريد الإلكتروني: البوط دصرئ

الملخص :

سنة الله تعالى في أرضه أن يختلف الناس في ابتاهاقم ومعتقداتم ولذلك يقول الله

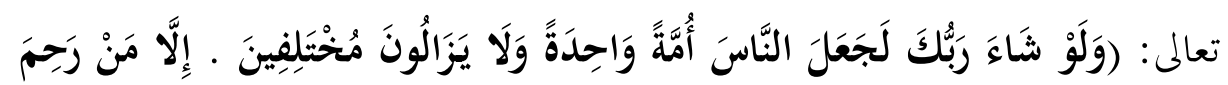
رَبُكَكَ...) وكان من أهم أثر الاختلاف وجود الفرق الإسلامية ومن بينهم فرقة المرجئة والتي كان ظهورها كرد فعل للخوارج والمعتزلة في شأن مرتكب الكبيرة، فالوضع السياسي وما حدث بين الصحابة رضوان الله عليهم كان سببا رئيسا لظهور القول بالإرجاء ثم تتطور حتى أصبح فرقة عقدية لها أصوها ومعتقداقا والتي هي محل دراستنا، وكان لهذه الأصول العقدية أثرها على الفرد والمجتمع من الناحية العقدية والأخلاقية، ولذلك أردت بعد توفيق الله تعالى لى أن أساهم في دراسة هذه الفرقة مبرزا جانبا هاما من خلال دراسة أصولها العقدية ألا وهو الجانب الأخلاقي ولذلك أسميت البحث بعنوان : ( الأصول العقديـة عند المرجئة وعلاقتها بالأخلاق ) عرض ومناقشة ومنهجي في البحث.، وهو المنهج التاريخي و التحليلي و المنهج النقدي: والحالة السياسية وأثرها في ظهور الفرق الإسلامية ، والتعريف بالمرجئة ونشأقهم - و رأيهم في ولئي حقيقة الإيمان وعلاقته بالأخلاق ومناقشتهم - ومعتقدهم في مرتكب الكبيرة وعلاقته بالأخلاق ومناقشتهم، وموقفهم من الشفاعة وعلاقتها بالأخلاق ومناقشتهم. الفرق الإسلامية. 


\section{Nodal Origins When Deferred And Their Relationship With Ethics (Presentation And Discussion)}

\section{Antar Saif Al-Nasr}

Department of Belief and Philosophy - Faculty of Fundamentals of Religion and Propagation - Al-Azhar University - Assiut - Egypt

\section{Email: ANtarAli1692.el@azhar.edu.eg}

\section{Abstract:}

The law of God Almighty is on His land that people differ in their attitudes and beliefs and that is why God Almighty says: (And if your Lord willed to make people one nation and still be different, among those who differed from the one who was different ... Its emergence as a reaction to the Kharijites and the Mu'tazila in the matter of the perpetrator of the big one. The political situation and what happened between the companions, may God be pleased with them, was a major reason for the emergence of the saying of delay, then it developed until it became a contractual group that has its origins and beliefs which are the subject of our study, and these contractual origins had an impact on the individual and pain Society of the ideological and moral, so I wanted after reconciling God Almighty me to contribute to this study of the band, highlighting an important aspect through the study of their assets Streptococcus not It is

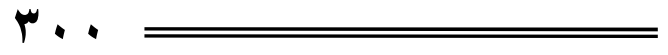




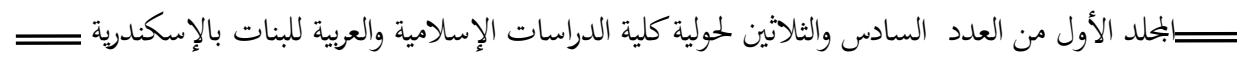
الأصول العقدية عند المرجئة وعلاقتها بالأخلاق (عرض ومناقشة الإية العرية للبنات

the ethical side, and therefore I called the research entitled: (Nodal Origins at the Deferred and Their Relationship with Ethics). Presentation and discussion - and in the reasons for choosing the subject - and my method in the research. - And their opinion on the truth of faith and its relationship to ethics and their discussion - and their belief in the perpetrator of the great and his relationship to ethics and their discussion, and their position on intercession and its relationship to ethics and their discussion.

Keywords: Doctrinal origins - Ethics - Intercession The truth of faith - Islamic difference. 
=ل =لمحلد الأول من العدد السادس والثلاثين لحولية كلية الدراسات الإسلامية والعربية للبنات بالإسكندرية عس الأصول العقدية عند المرجئة وعلاقنها بالأخلاق (عرض ومناقشة)

$\boldsymbol{Y}, \mathrm{Y}=$ 


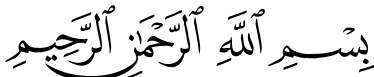

\section{المقدمة}

الحمد لله رب العالمين و الصـلاة والسـلام على أشـرف المرسلين سيدنا

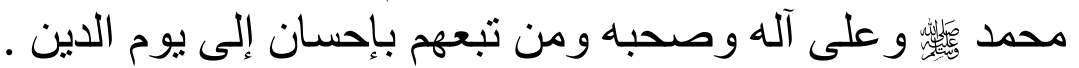
أما بعد بعر بأن

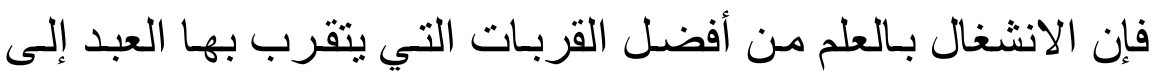

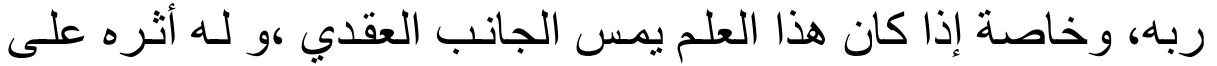

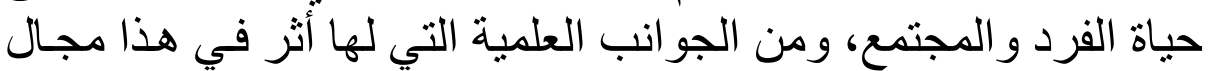

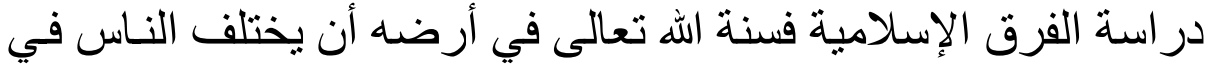

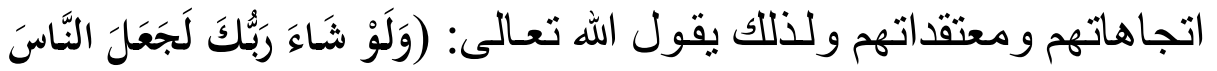

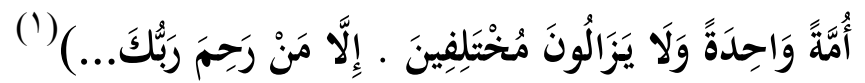
والنبي

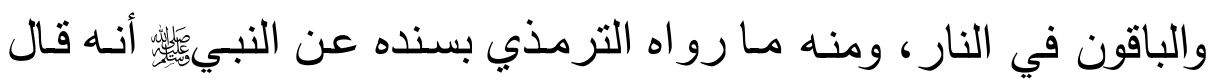

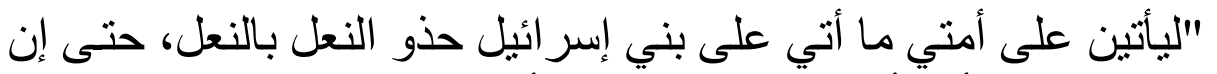

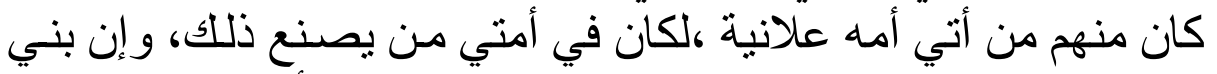

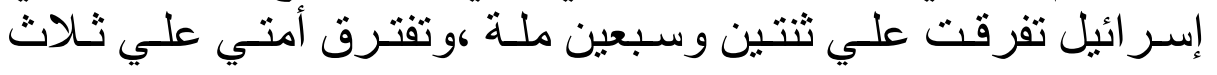

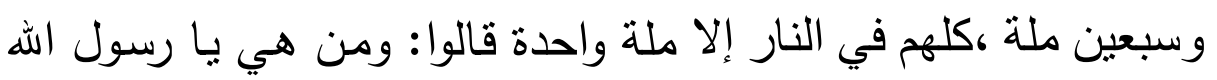

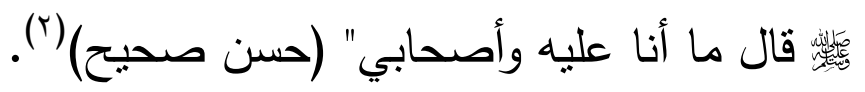

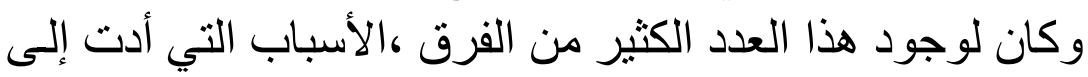
ظهوره ومن بين الفرق التي ظهرت في الإسلام، فرقة المرجئة و التي التي التي

1 - سورة هود الآية رقم (1) ال وجزء من الآية (19 (1)).

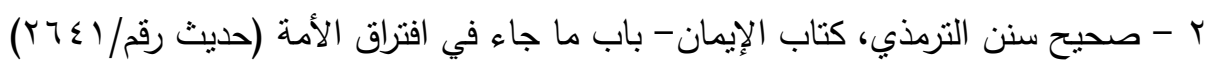

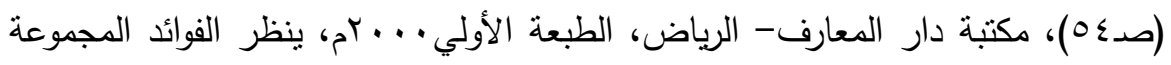

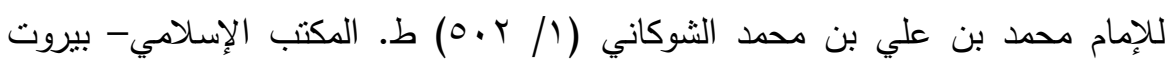




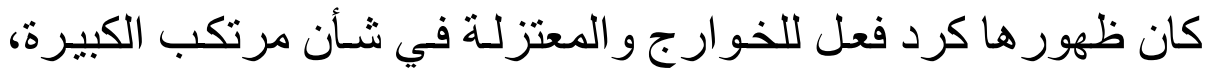

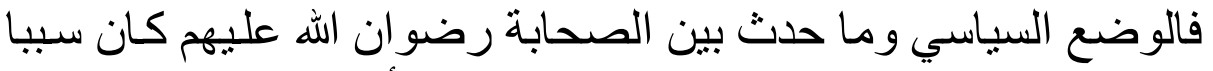

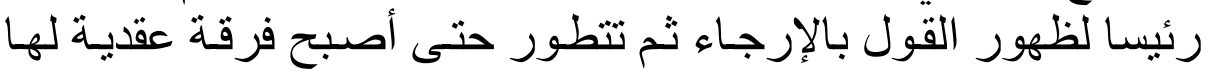

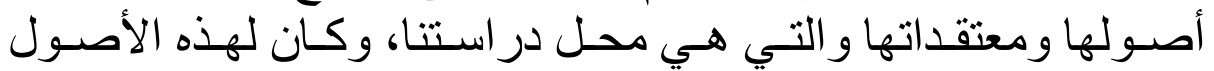

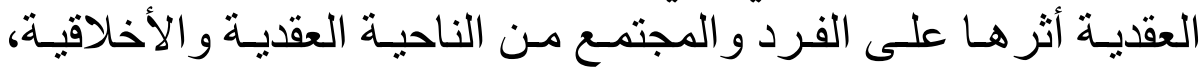

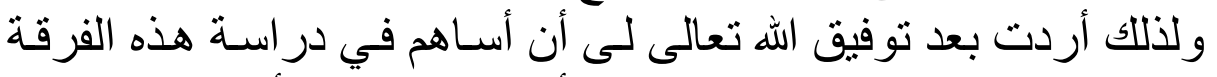

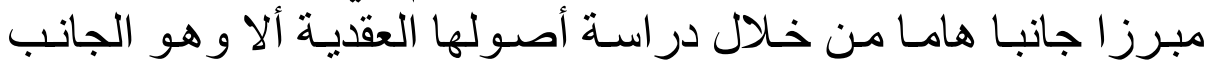
الأخلاقي ولذلك أسميت البحث بعنو دران

\section{( الأصول العقديـة عند المرجئة وعلاقتــها بالأخلاق )}

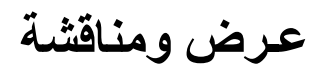

وقدمة وتمهيد وأبحثي: مقئة مباحث وخاتمة

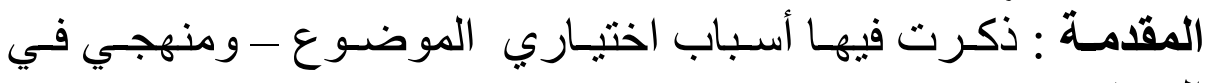
البحث.

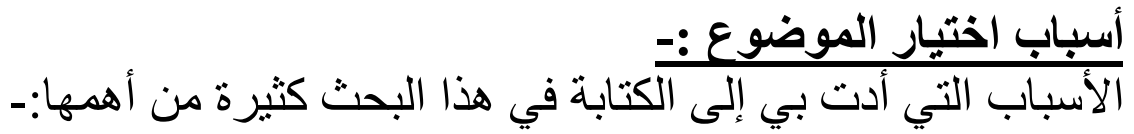

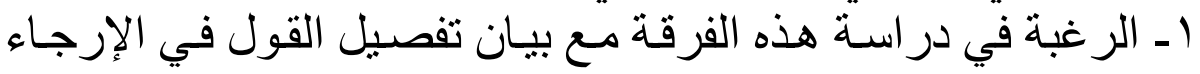

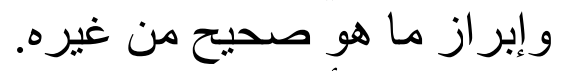

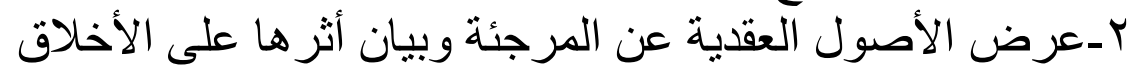

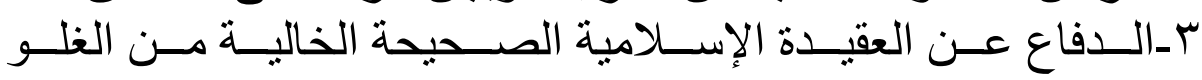

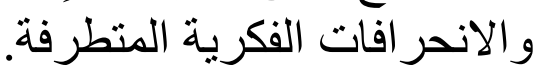
إلى غير ذلك من الأسباب التي دعتني إلى الكتابة في هذا البحث. منهجى في البحث لـ البحث المناهج الأتية:-

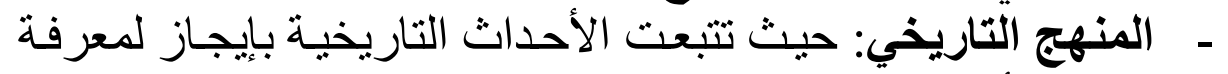
كيف نشأة فرقة المرجئة . 


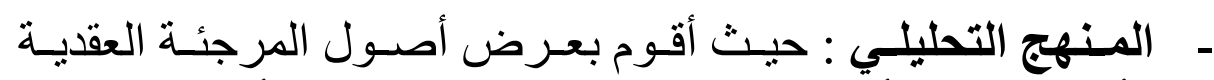

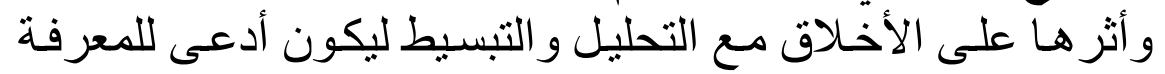

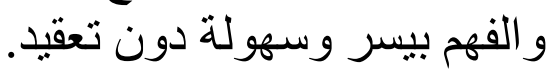

- المنهج النقدي: حيث أقوم بنقد الأصول العقدية التى اعتمدت عليها

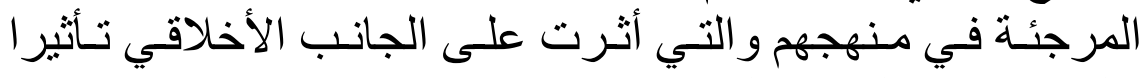
سلبيا مع بيان الوجهة الصحيحة في هذا.

\section{أما التمهيد : الحالة السياسية و أثرها في ظهور الفرق الإسلامية} وأما المباحث: المبث:

المبحث الثاني: رأيهم في حقيقة الإيمان وعلاقته بالأخلاق ومناقشتهم بالنه المبحث الثالث: معتقدهم في مرتكب الكبيرة و علاقته بالأخلاق

ومناقشتهم

المبحث الرابع : موقفهم من الثفاعة وعلاقتها بالأخلاق ومناقشتهم.

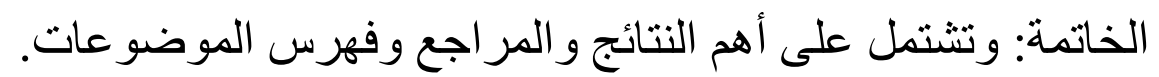

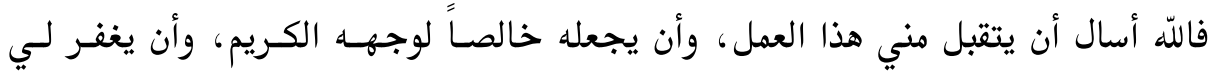

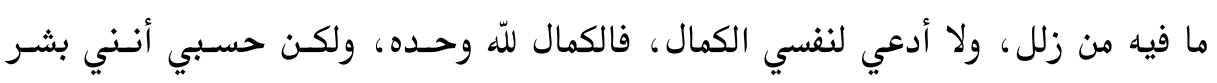

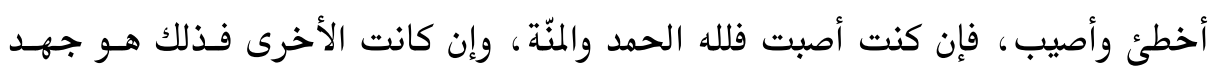

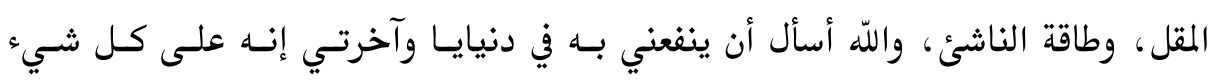

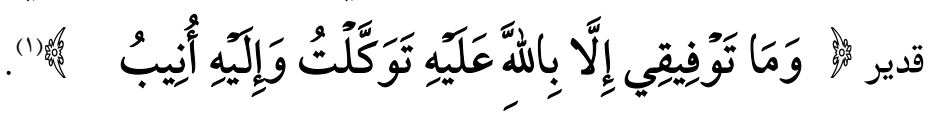

1 - سورة هود من الآية رقم (^^). 
=ل =لمحلد الأول من العدد السادس والثلاثين لحولية كلية الدراسات الإسلامية والعربية للبنات بالإسكندرية عس الأصول العقدية عند المرجئة وعلاقنها بالأخلاق (عرض ومناقشة)

$\mu \cdot 7=$ 


\section{$1+0$}

\section{الحالة السياسية وأثرها في ظهور الفرق الإسلامية}

عاش المسلمون في الصدر الأول في ظل حياة النبي ـ صليى الله عليه

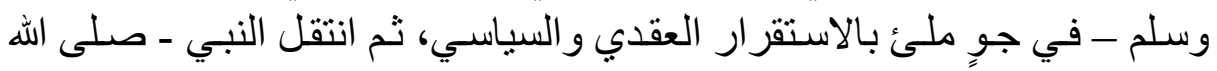
عليه وسلم- إلى الرفيق الأعلى ويتولى سيدنا أبو بكر الصديق خلافيق الصفة المسلمين

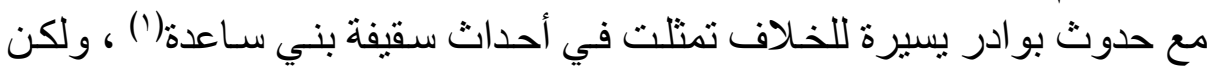
سر عان ما استقر الخلاف و استتب الأمن و هدأت الأوضاع،وفي هذا يقول فئل الإمـام

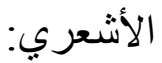

( وأول ما حدث من الاختلاف بين المسلمين بعد نبيهم صلى الله عليه وسلم اختلافهم في

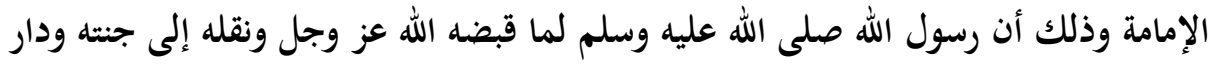

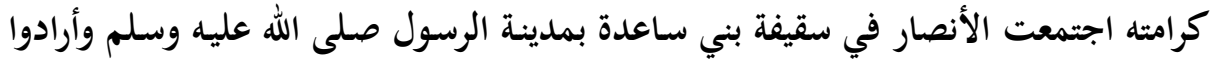

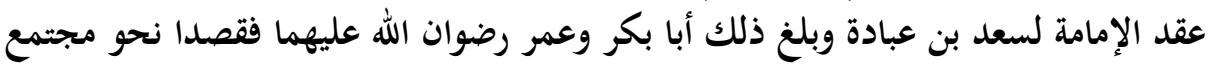

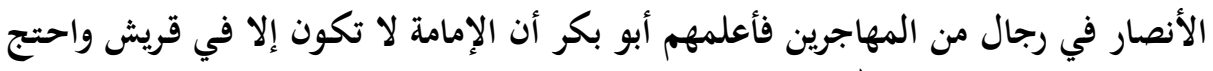

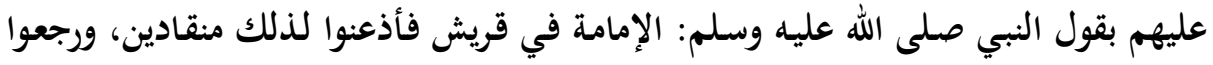

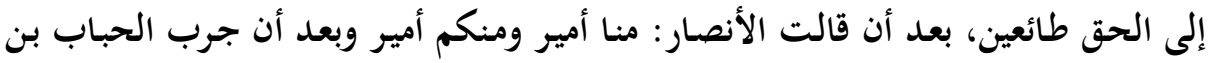
المنذر سيفه) الى طائن

ولكن أعداء الإسلام يتربصون بهذا الدين الحق، ويضمرون له الكيد منذ

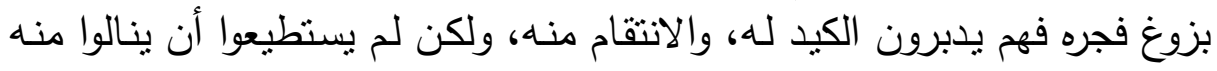

1 - ظلة كانوا يجلسون تحتها في المدينة، وبنو ساعده حي من الأنصار، وهي بجوار بئر

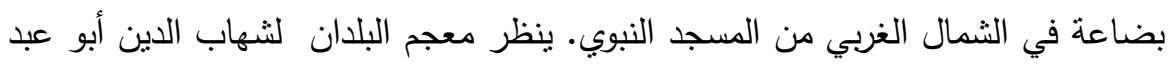

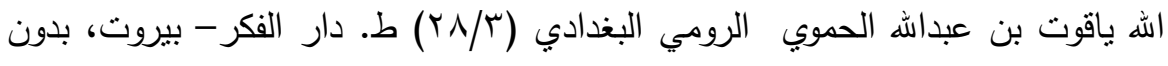
تاريخ.

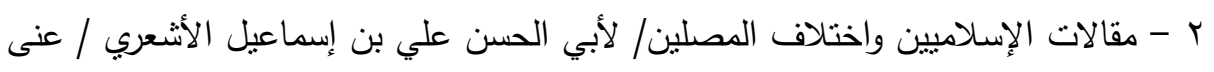
بتصحيحه: هلموت ريتر ( صـ ب) / الناشر : دار فرانز شتايز ، بمدينة فيسبادن (ألمانيا)

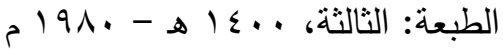




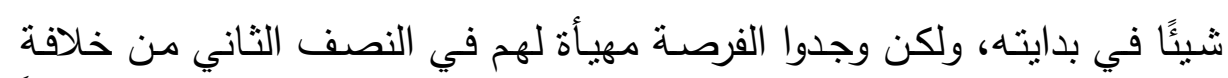

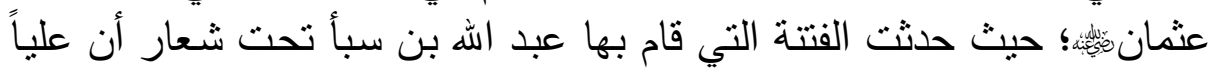

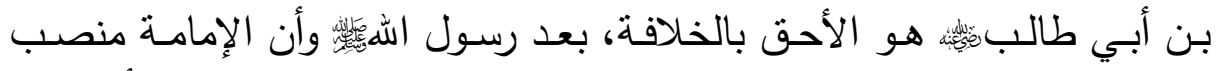

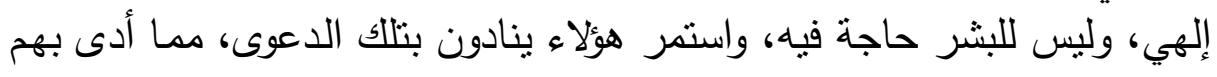

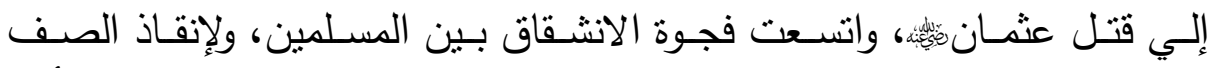

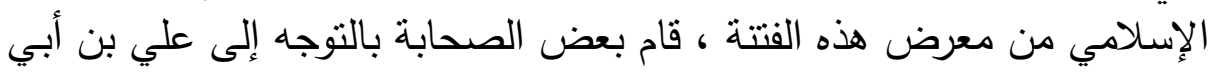

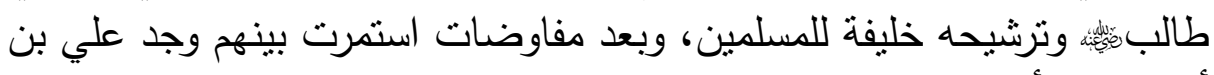

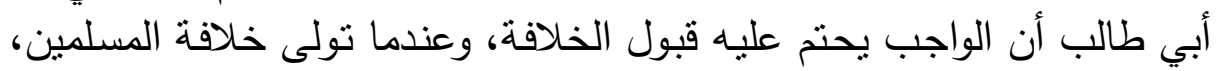

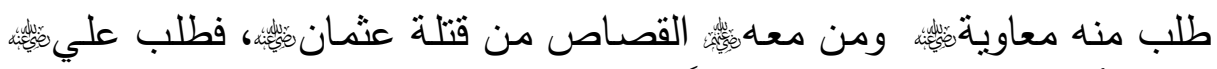

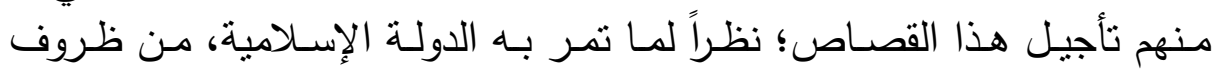

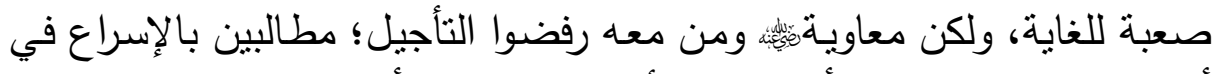

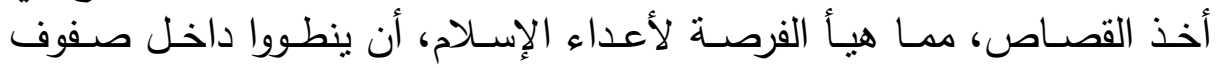

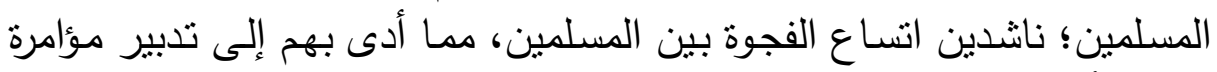

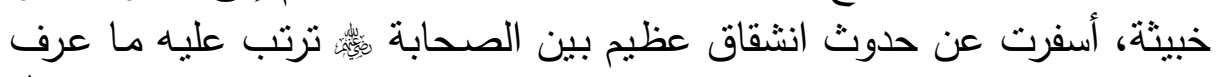

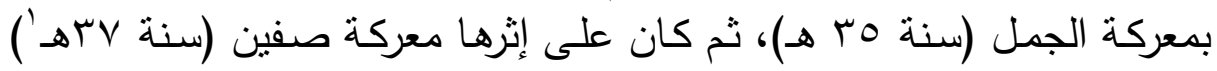

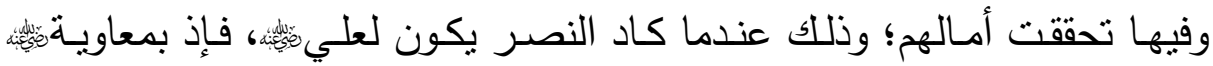

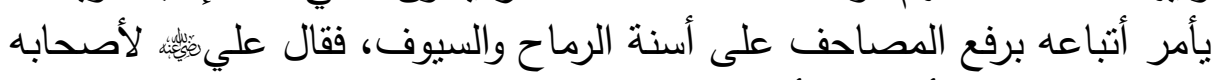
إنها خدعة، ولكن أصحابه أرادوا منه قبول ذلك الكئ فوافق؛ دفعا لإراقة الدماء.

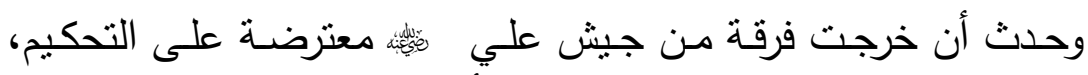
سميت بالخوارج، وعلى النقيض استمرت فرقة أخرى نسير خلف الإنمام علي

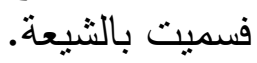

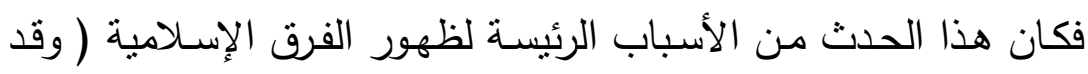

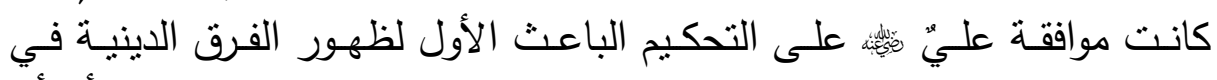
الإسلام، فقد كان في معسكر الخليفة بعض المسلمين المتعصبين الذين رأوا أن الني

1- مكان علي شاطئ الفرات من الجانب الغربي بين الرقة وبالس في أخر حدود العراق وأول

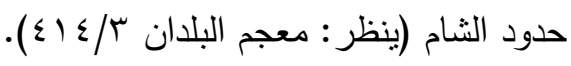

$\mu \cdot \Lambda=$ 


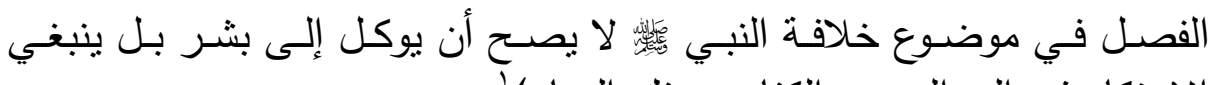

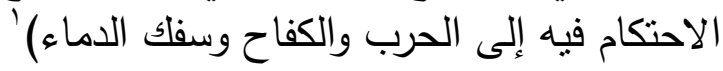

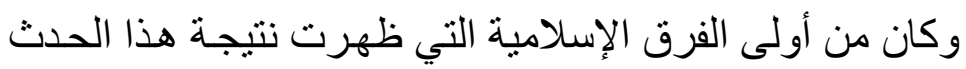

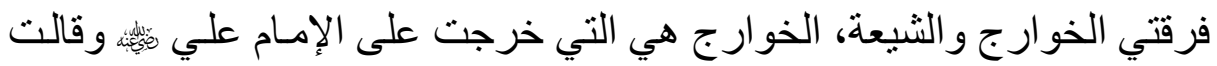

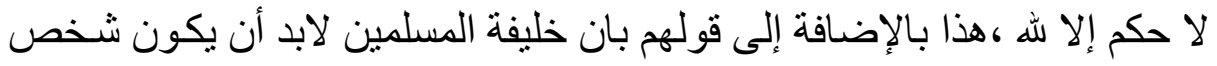

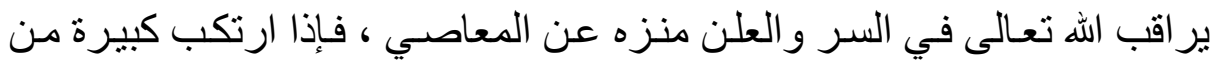

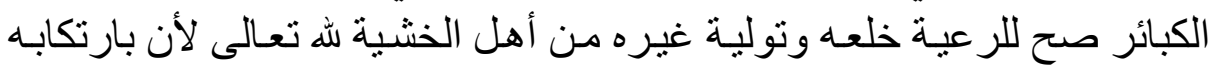
للكبيرة أصبح كافر ا.وما جعل الله تعالى للكافرين على المؤمنين سبيلا.

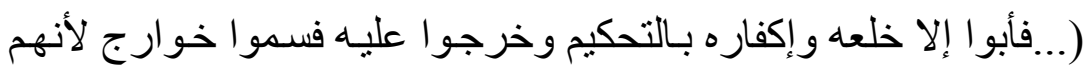

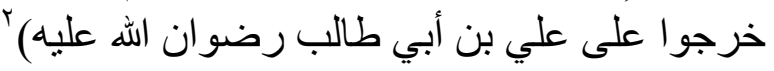

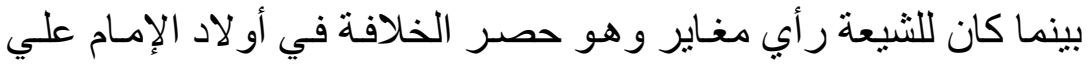

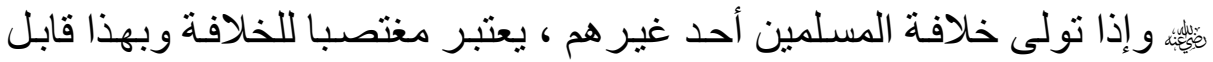
الثيعة حكم الأمويين بالرفض ولافئ وعدم الدخول تحت لو لاء لاء الخلافة.

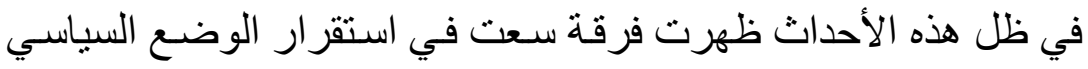

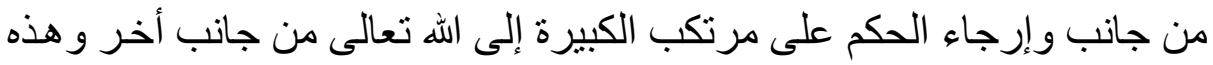

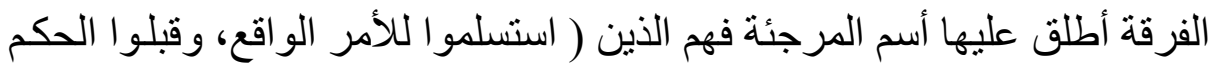

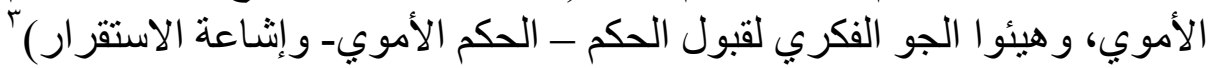

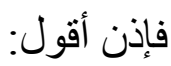

أن الحالة السياسية و أقصد بهـا هنـا، قضية الخلافة كانت سببا رئيسـا، لظهور

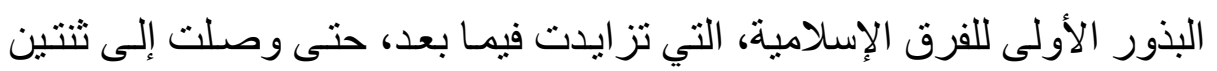
وسبعين أو ثلاث وسبعين فرقة، ولتحليل نثأة المرجئة بشيء من التئية التفصيل يتبين

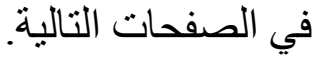

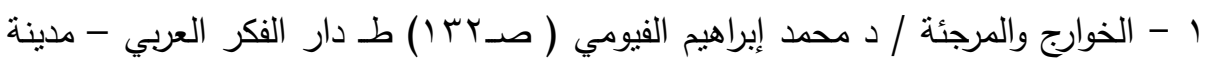

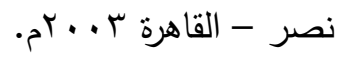

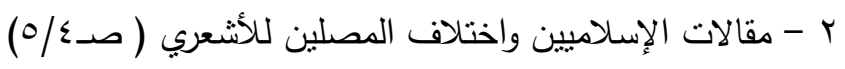

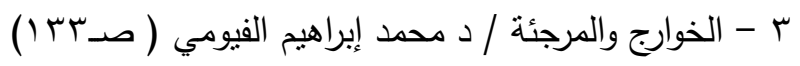


ב=لبحلد الأول من العدد السادس والثلاثين لحولية كلية الدراسات الإسلامية والعربية للبنات بالإسكندرية عس الأصول العقدية عند المرجئة وعلاقتها بالأخلاق (عرض ومناقشة) 


\section{الامبحث الأول \\ التعريف بالمرجئة ونشأتههي}

معرفة دلالة الألفاظ من أهم المعارف؛ لألغاء اللغة اللفظ لا يفهم إلا إذا عرف معناه وبناء

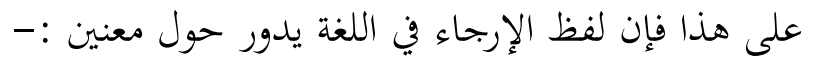

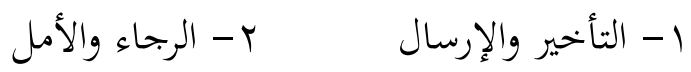

1- التأخير والإرسال :ومنه أرجأ الأمر : أخره، وترك الهمزة لغة، وأرجأت الأمر وأرجيته إذا أخرته . ألأرجاء والإرجاء: التأخير مهموز، ومنه سميت الثُرجئلة .

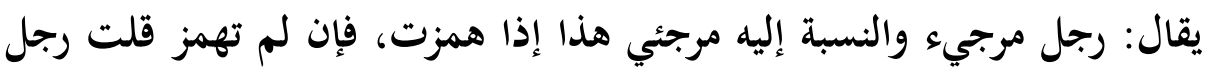

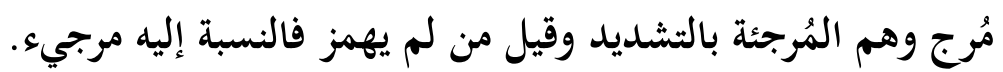
فنقول ر جل مرجئي ومرجي في النسب إلى الى المرجئ المئلة والمرجية.

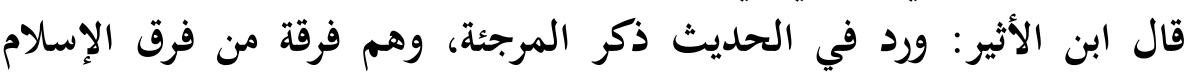

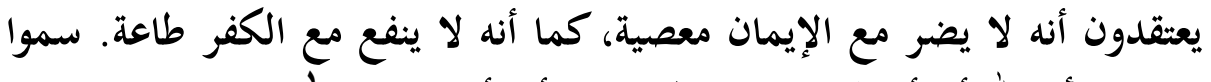

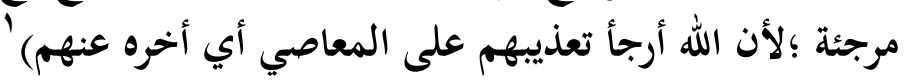

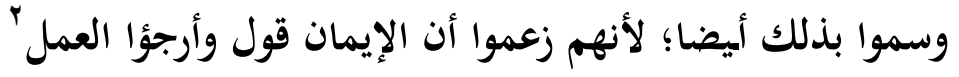

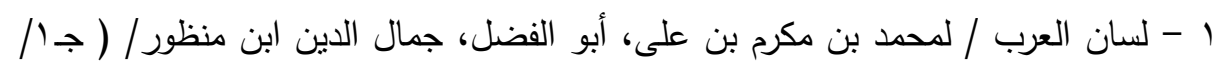

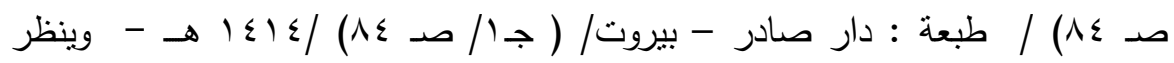
كتاب التعريفات/ لعلي بن محمد بن علي الزين الثريف الجرجاني - تحقيق: ضبطه

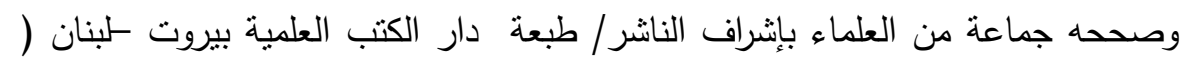

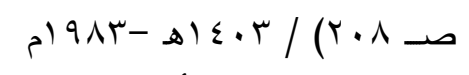
r - غريب الحديث/ أبو محمد عبد اله بن مسلم بن فتنيبة الدينوري /تحقيق: د. عبد اله اله

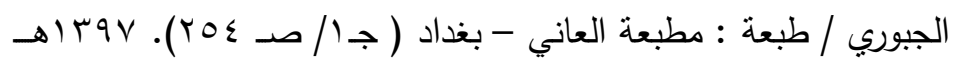




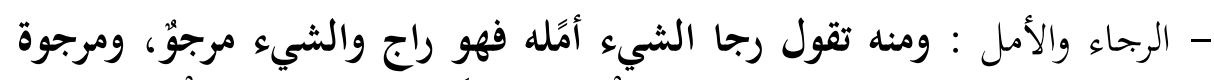

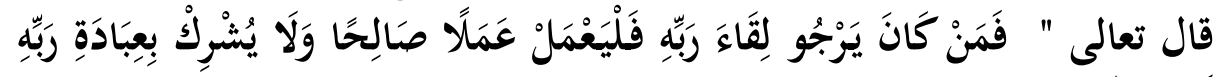

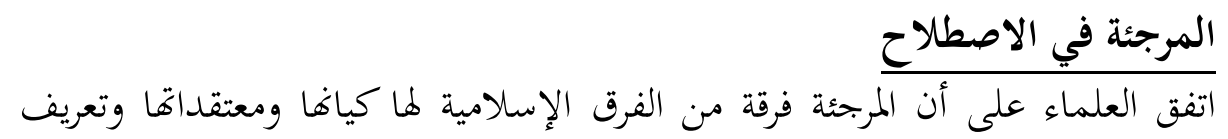

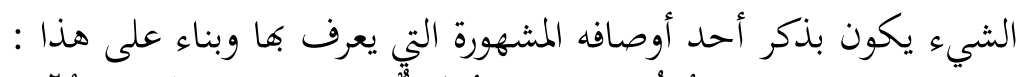

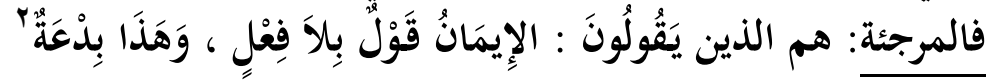

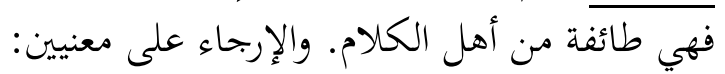

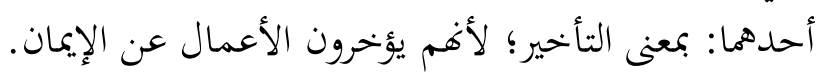

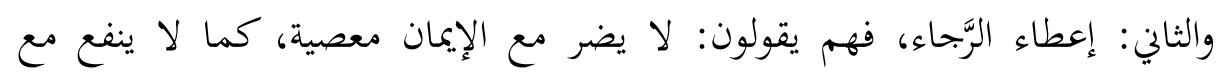
الكفر طاعة.

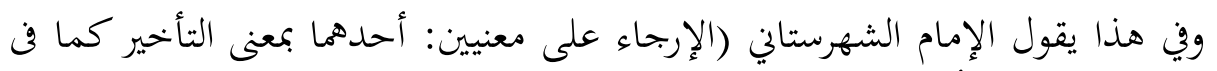

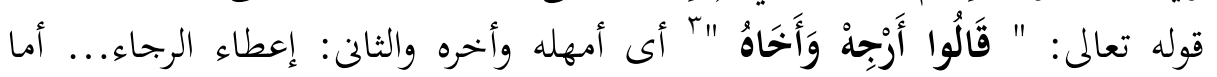

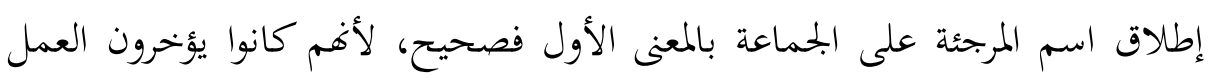

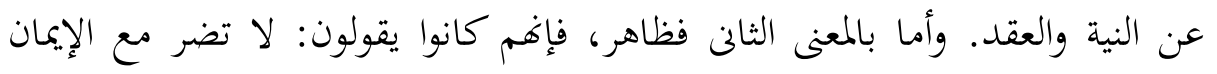

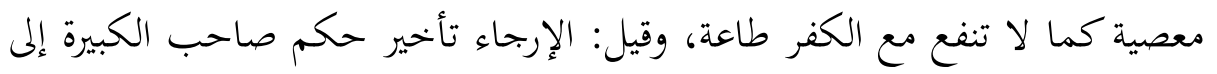

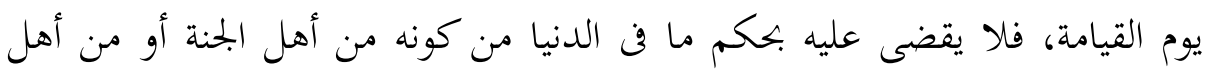

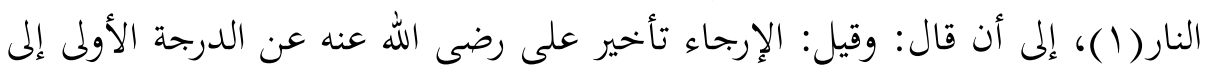
الرابعة)

(1) - سورة الكهف جزء من الآية رقم (·ل (1) .

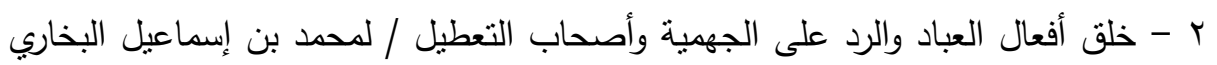

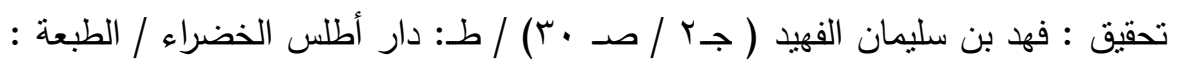

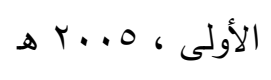

ب - سوره الثعراء جزء من الآية رقم ( آبا).

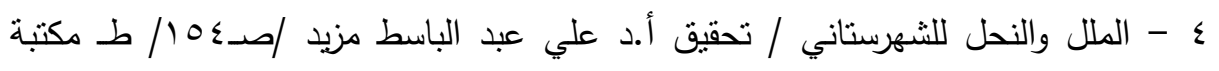

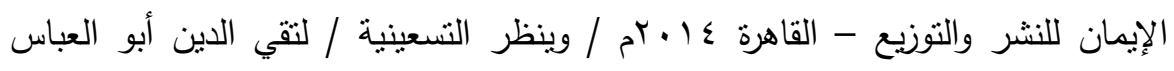

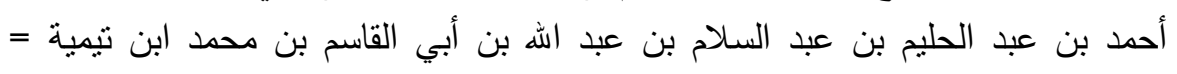


وقد ذكر صاحب كتاب السنة بسنده أنه قال : أخبروني حرب بن إسماعيل الكرماني

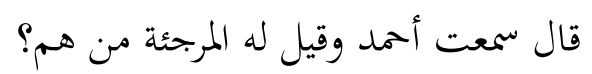

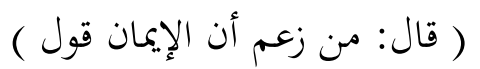

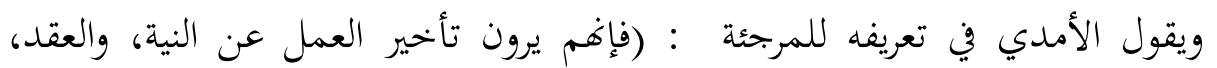

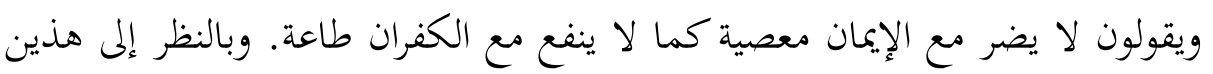
القولين سموا مرجئة)'

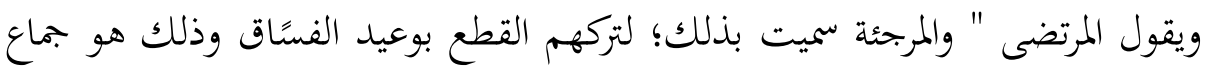

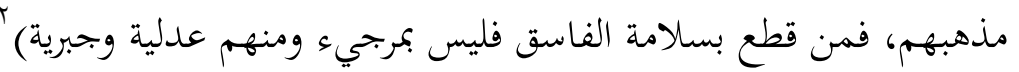

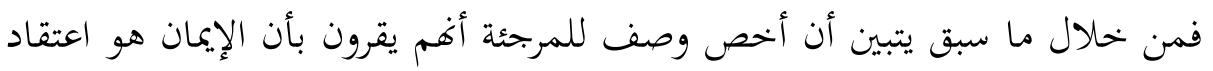

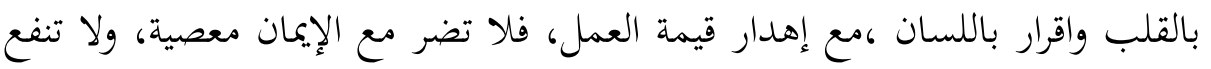

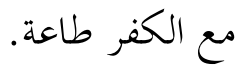

\section{ثانيا: نشأة المرجئة وزمن ظهورهم}

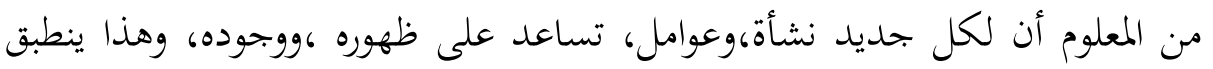

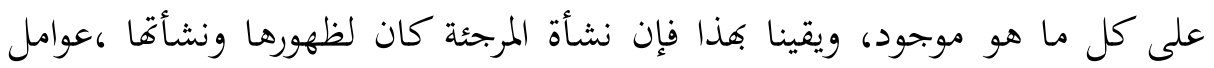

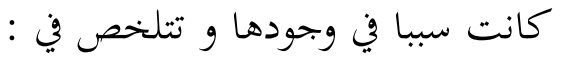

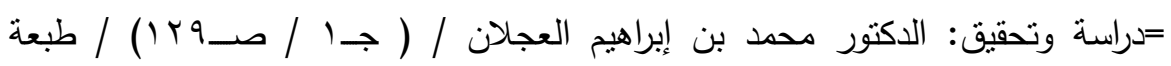

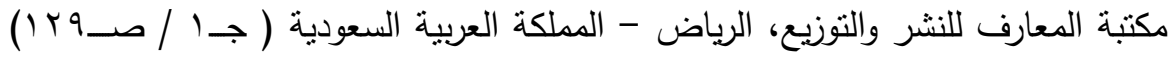

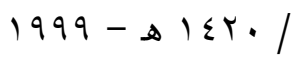

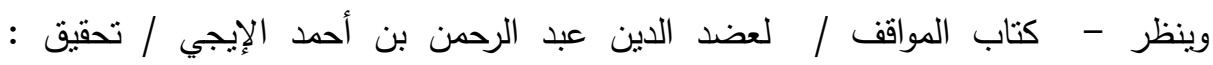

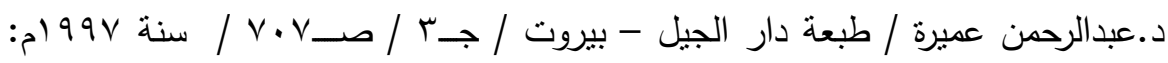

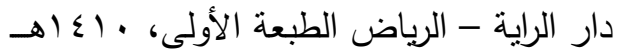

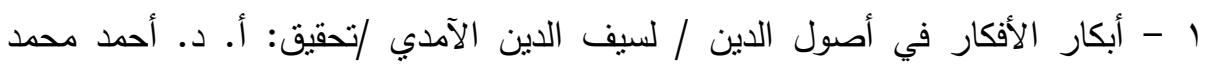

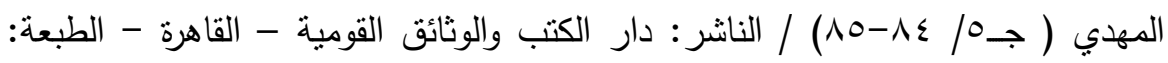

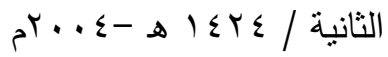
r - المنية والأمل في شرح الملل والنحل / لأحمد بن يحى المرتضى / تحقيق د / محمد

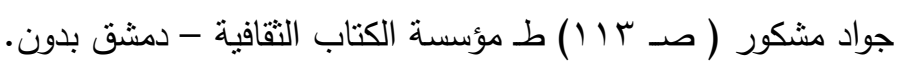


- المناخ السياسي ( ظاهرة الإرجاء وعلاقتها بالخلافة والإمامة ) .

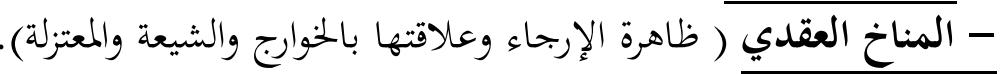

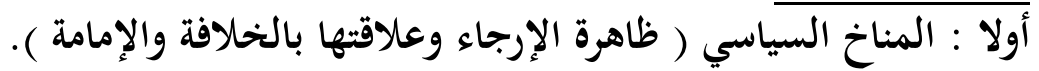

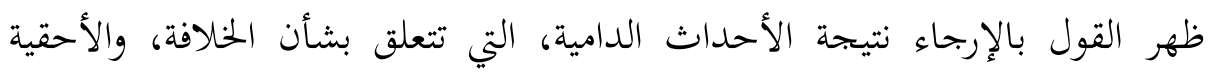

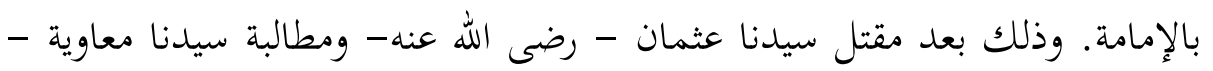

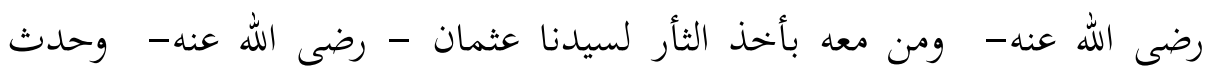
خحلاف ونزاع ترتب عليه أن بعض الصحابة اعتزل هذه الفتنة وأرجأ الأمر فيها إلى الله وحداث

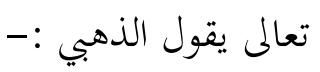

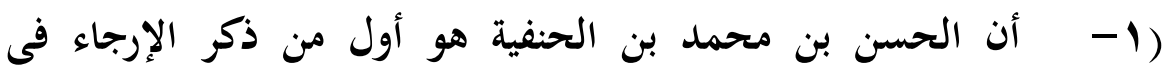

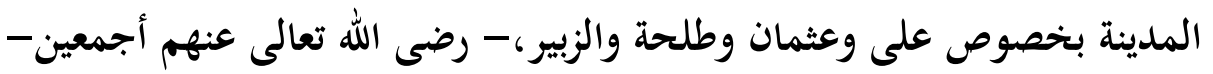

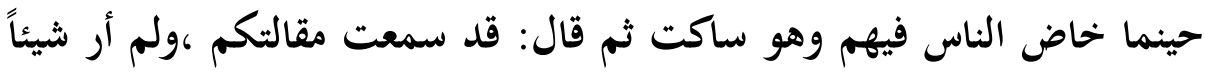

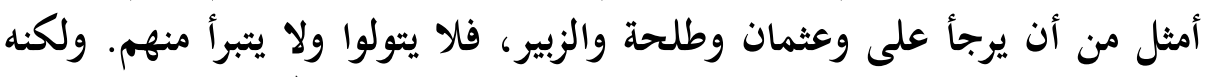

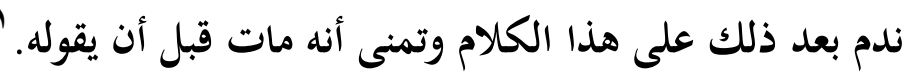

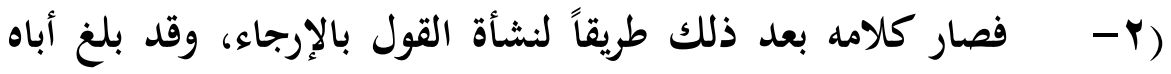

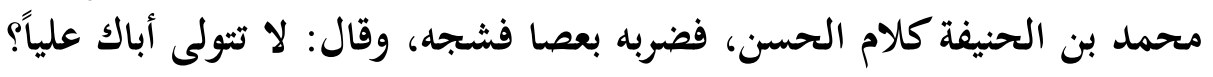

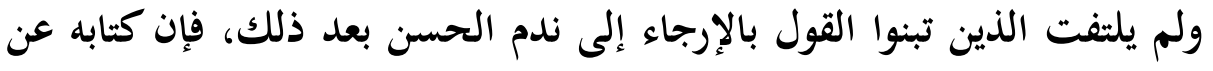

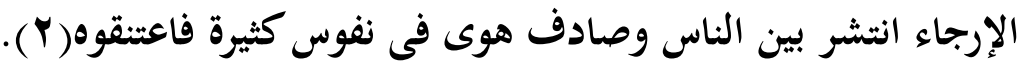

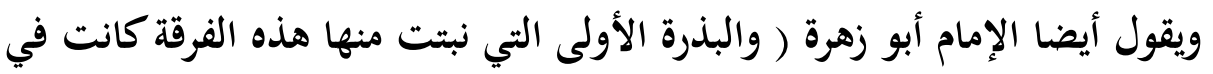

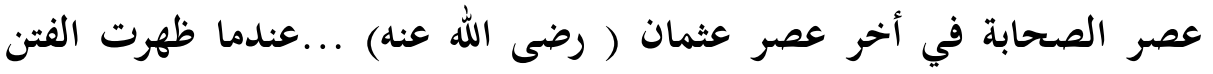

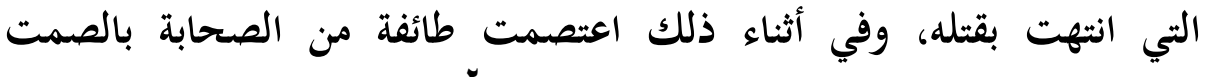

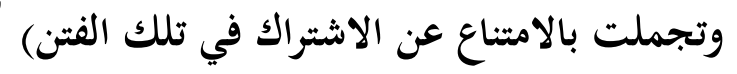

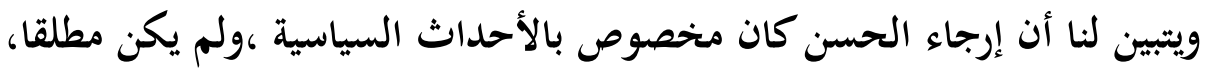

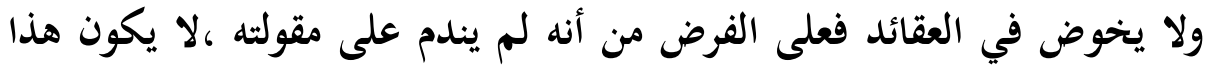

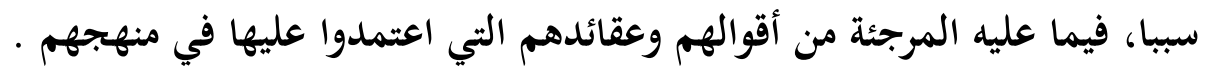

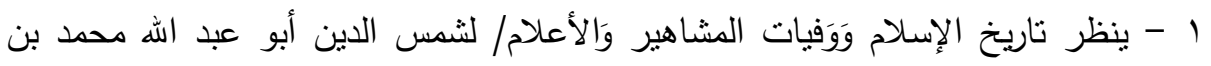

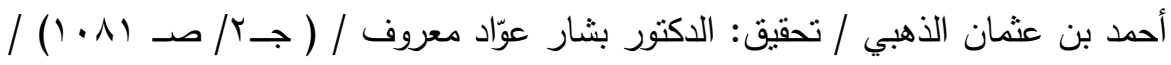

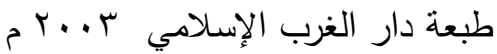

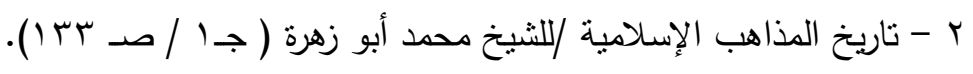




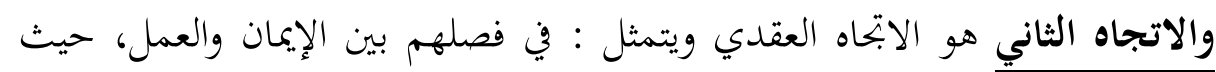

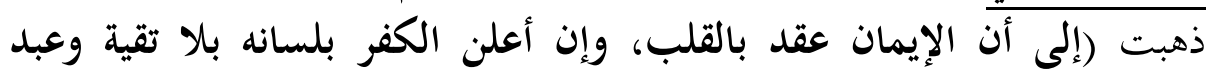

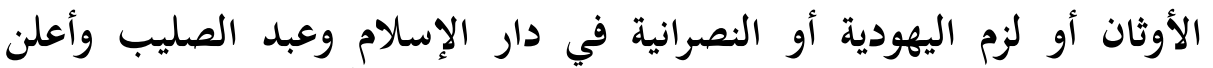

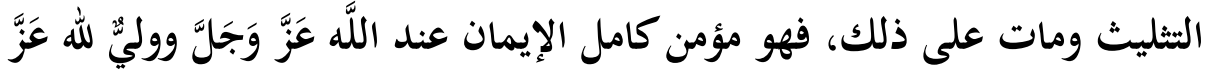

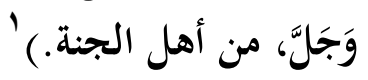

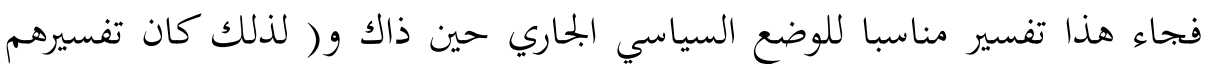

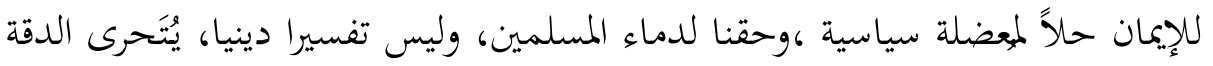

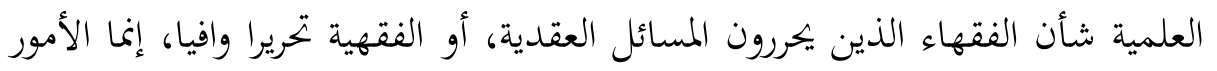

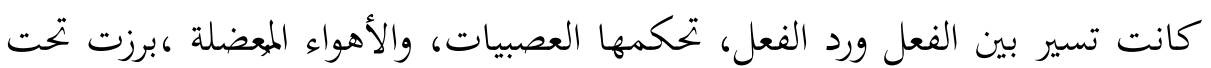

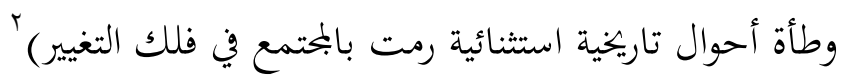

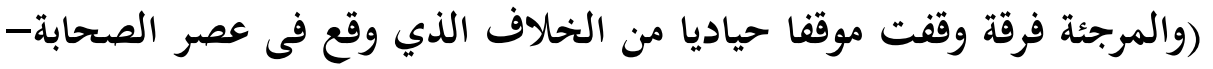

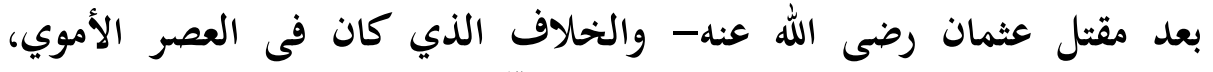

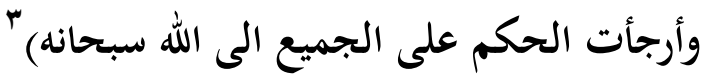

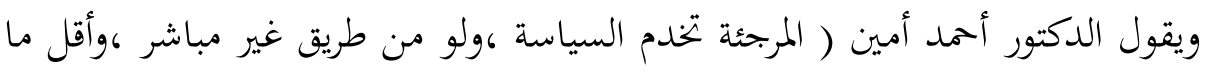

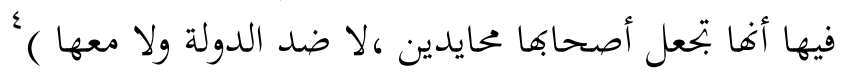

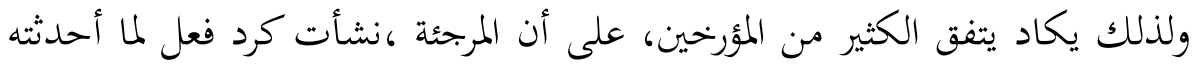

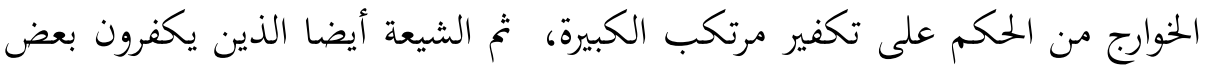

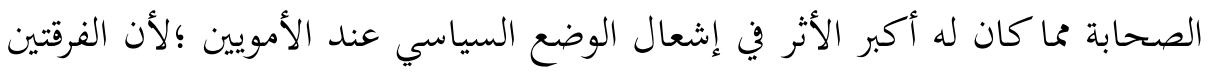
يكفران الأمويين لأغم في نظرهم مغتصبون للخحلافة.

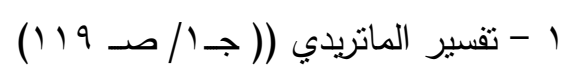

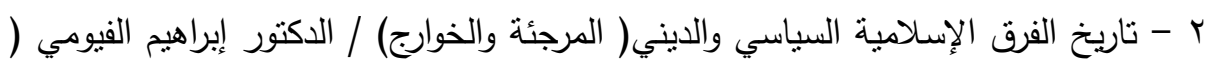

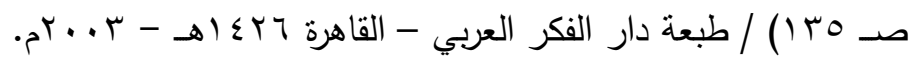

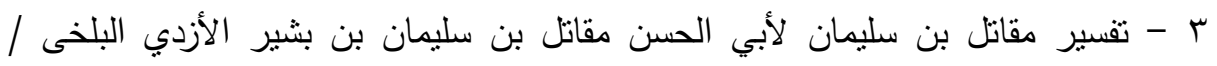

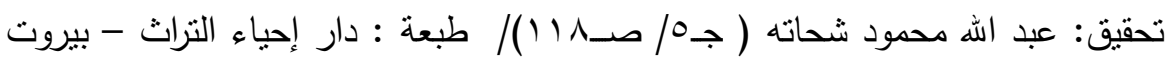

$$
\text { ه } 1 \leqslant \text { r }
$$

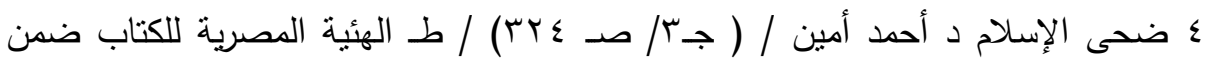

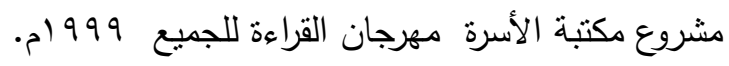




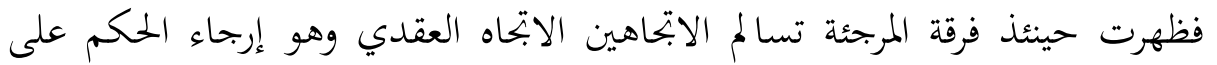

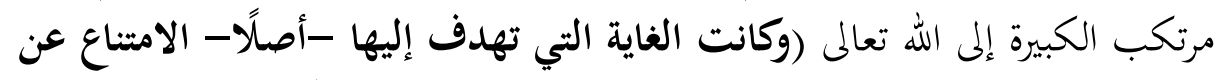
التسرع في إصدار الأحكام على أعمال الصحابة والتابعين)

\section{ويقول ابن تيمية :}

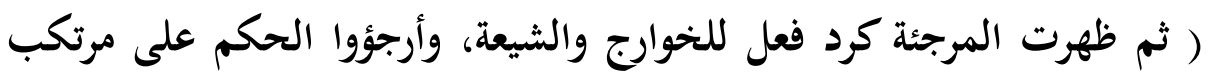

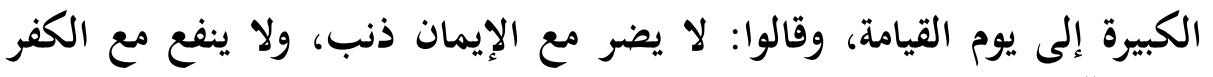
طاعة) الكيرن الى وتحقيق القول بأن المرجئة ظهرت كرد فعل للخوارج والشيعة يوضح لنا أن الامر يتعلق بالمنظور السياسي العول بان المري

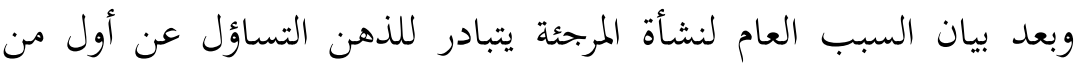

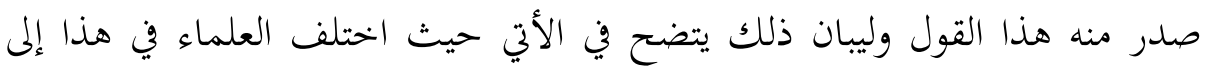

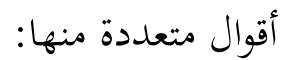

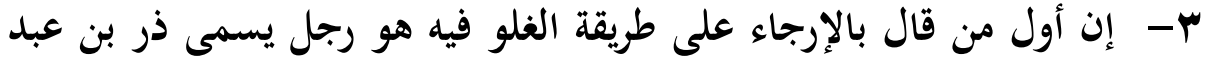

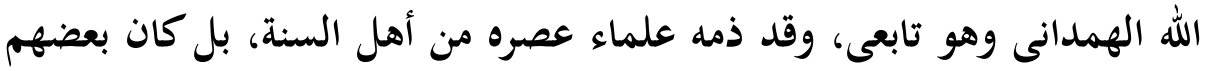

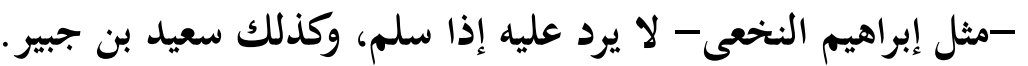

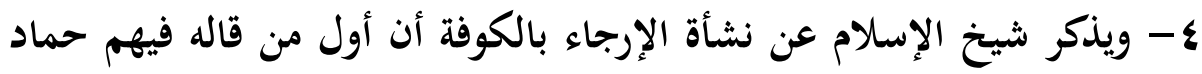

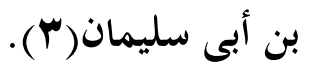

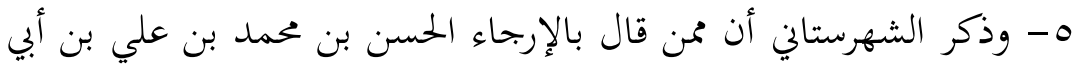

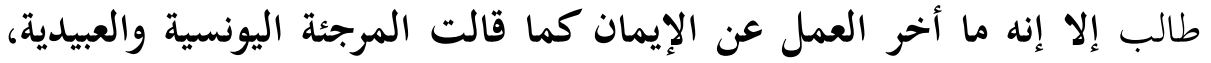

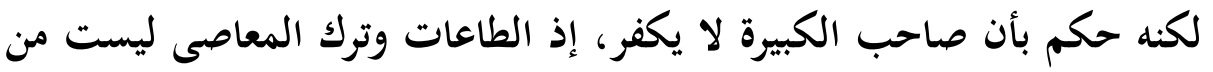
أصل الإيمان حتى يزول الإيمان بزوالها). 7- وذكر ابن تيمية أن القول بالإرجاء ظهر في أوانحر عهد الصحابة الصابة رضوان

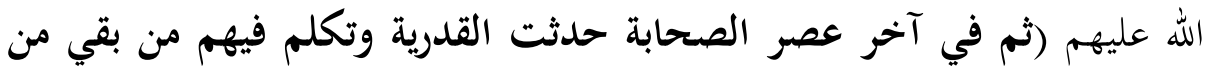
1 - تقسير الماتريدي (تأويلات أهل السنة)/ لمحمد بن محمد بن محمود، أبو منصور

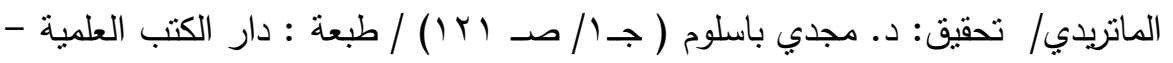

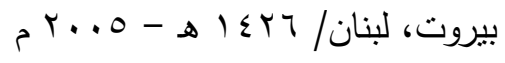

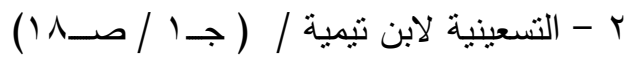


الصحابة كابن عمر وابن عباس ووائلة بن الاسقع وغيرهم وحدثت أيضا بدابة الابنة

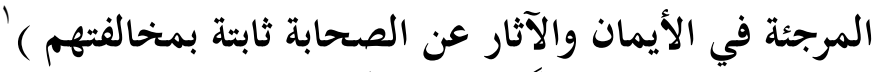

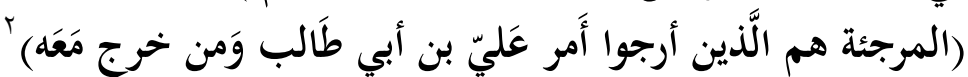

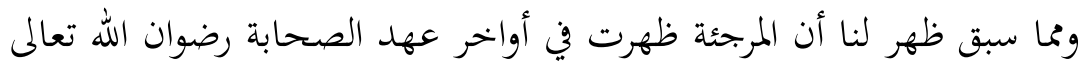

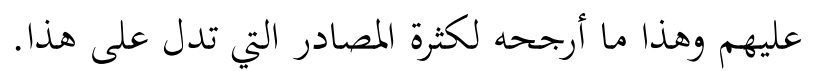

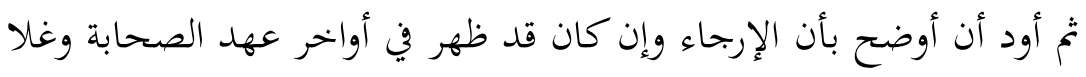

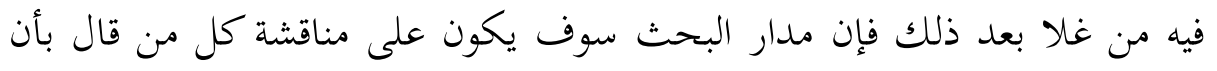

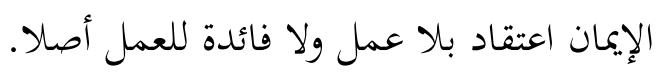

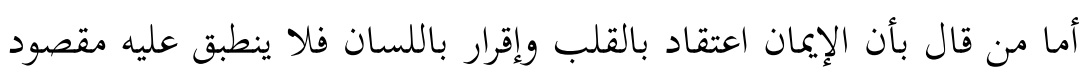

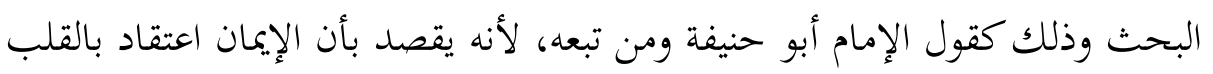

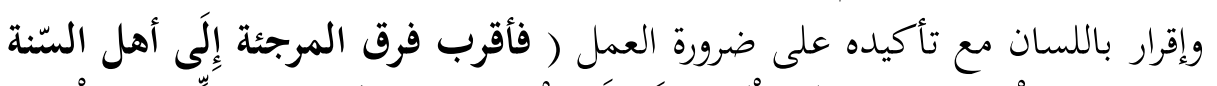

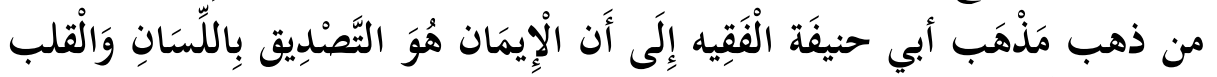

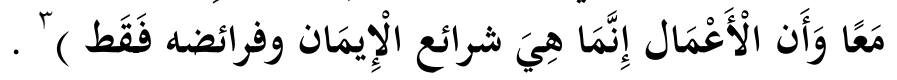

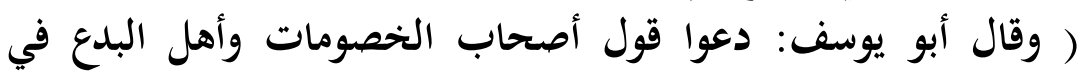

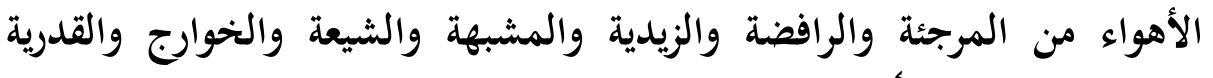
والمعتزلة والجهمية) ومن نافلة القول :

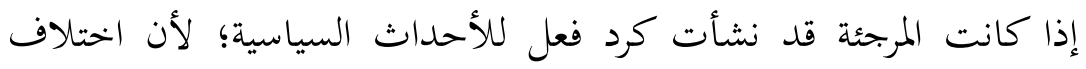

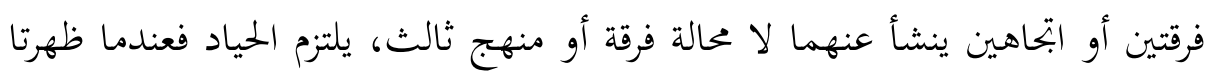

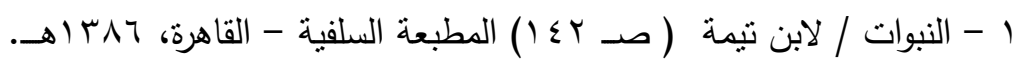

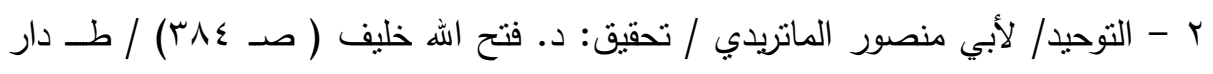

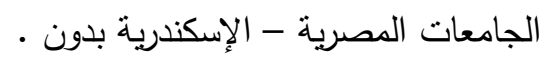

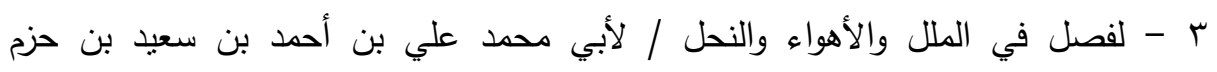

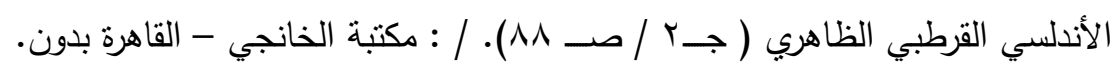

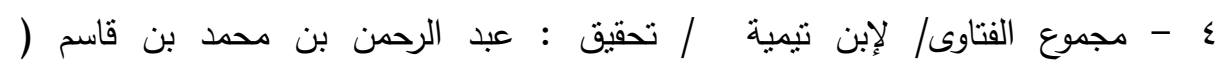

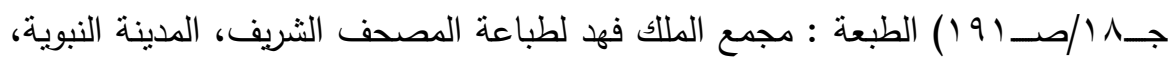

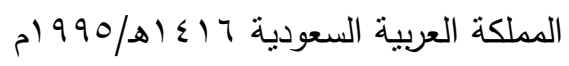




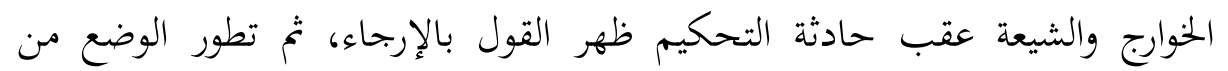

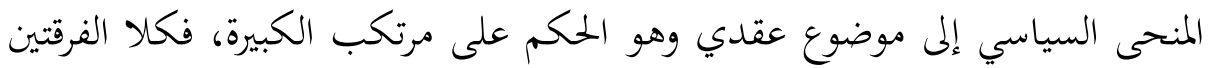

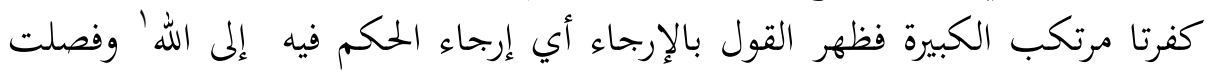

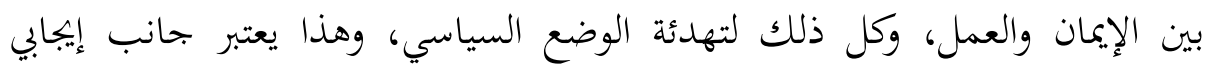

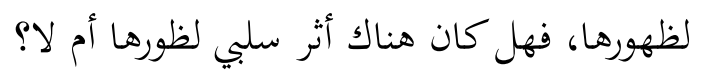

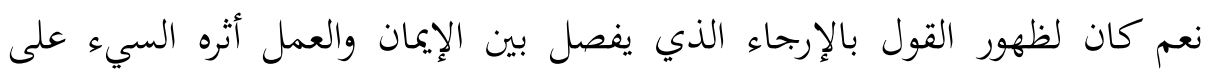

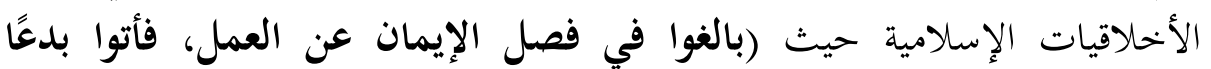
وضلالات) الأنافيات

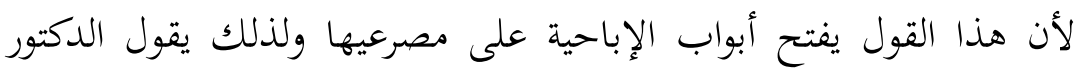

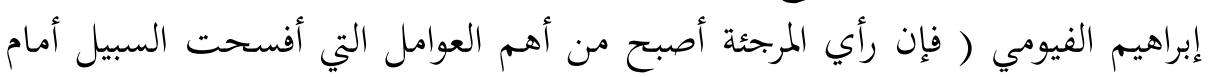

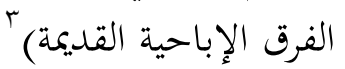

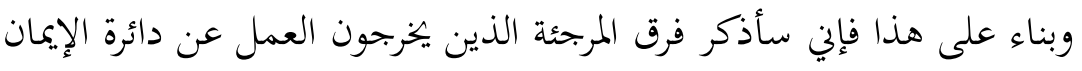

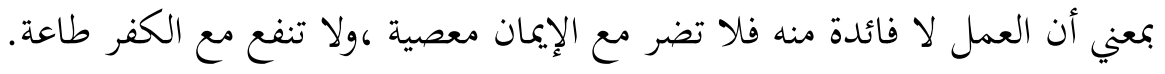

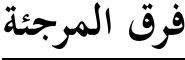

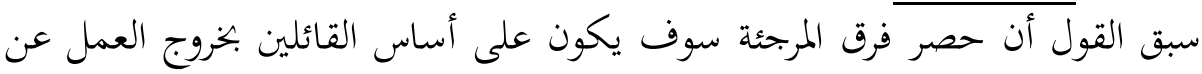

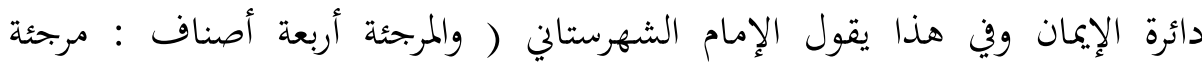

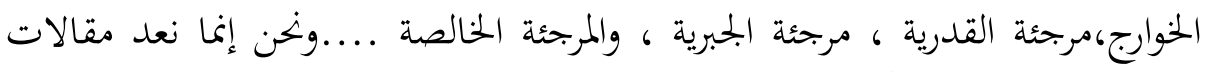

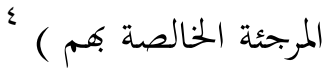

1- اليونسية : أصحاب يونس بن عون النميري:زعم أن الإيمان هو المعرفة

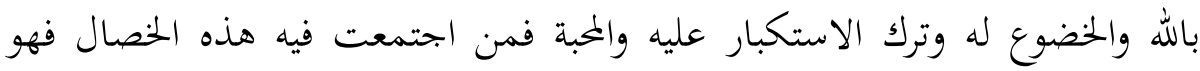

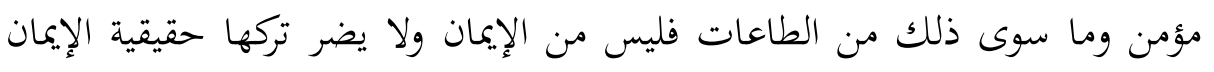
ولا يعذب على ذلك إذا كان الإيمان خالصا واليقين صادقا.

1 - ينظر ظاهرة الإرجاء في الفكر الإسلامي د / سفر بن عبد الرحمن الحوالي ( صـ .$(r \cdot T$

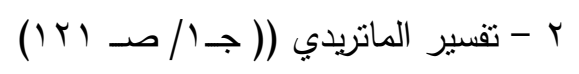

r - ناريخ الفرق الإسلامية السياسي والديني الخوارج والمرجئة / د. إبراهيم الفيومي ( صـ

ع - الملل والنحل للثهرستاني ( صدء 1). 


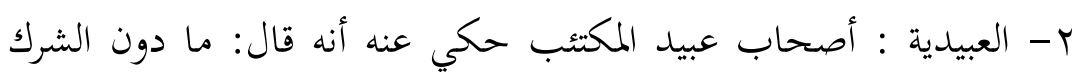

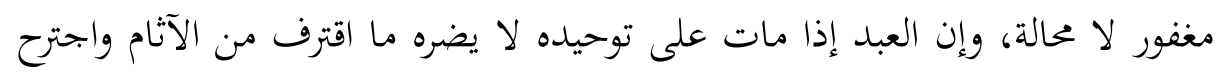

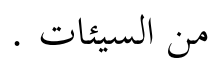
r- الغسًانِيّة : أصحاب غسان الكوفي الذي زعم بأن الإيمان هو المعرفة بالله وبرسوله والإقرار بما جاء جملة لا تفصيلا.

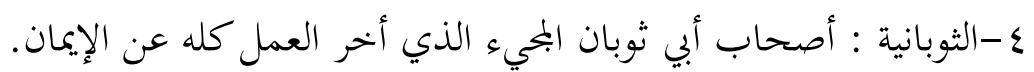

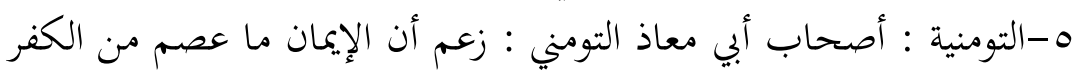

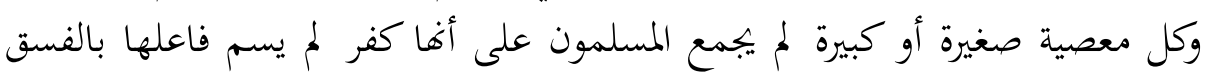

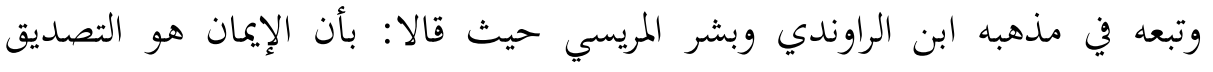
بالقلب واللسان جميعا.

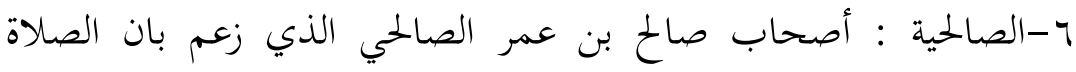

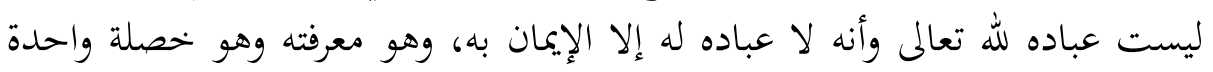

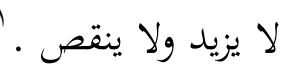

هذه هي أهم فرق المرجئة الخالصة ويتفقون جميعا على إخراج العمل عن دائرة الإيمان

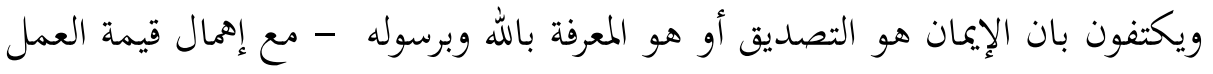

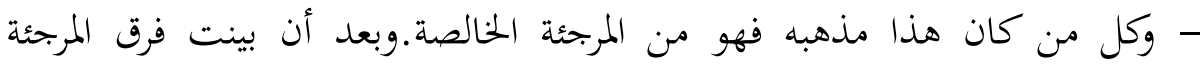

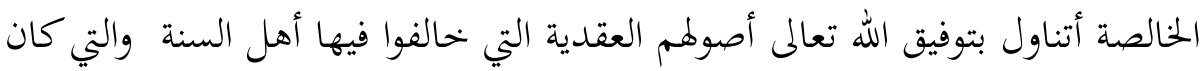

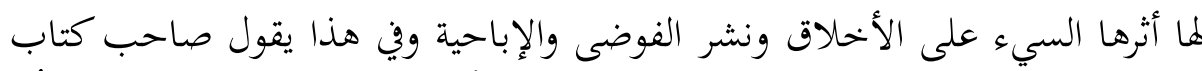

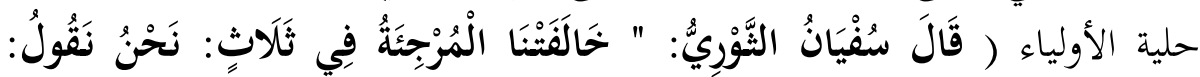

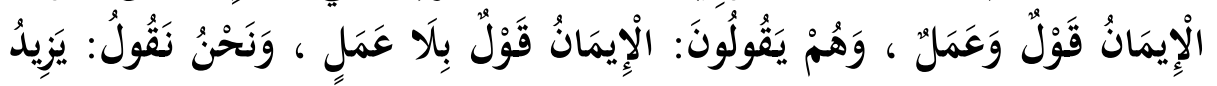

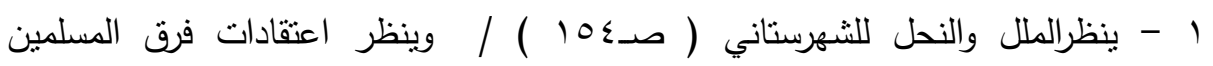

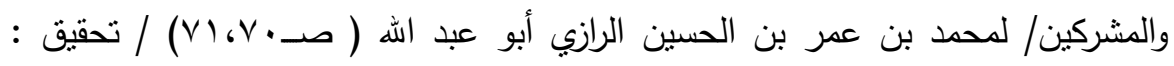

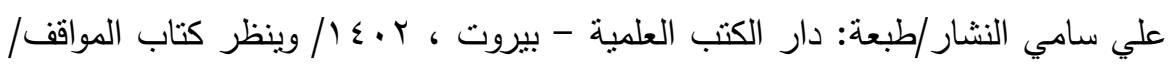

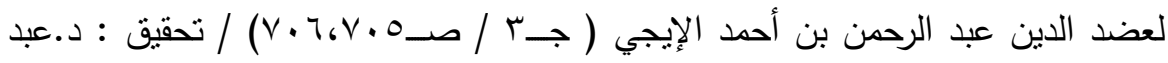

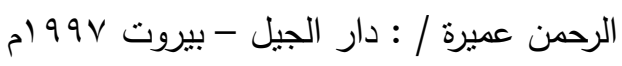




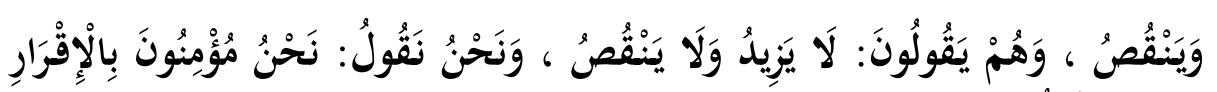

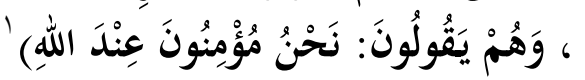

ومما يفهم من خحلال الدراسة الموجزة لنشأة المرجئة تبين أن ليس لهم مصدرا

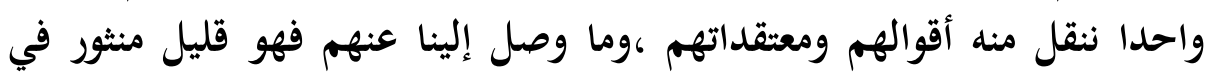
ثنايا الكتب والمؤلفات،وهم يكادون يجمعون على ومعلى المحاور الأتية : ا - عدم الخوض فيما جرى بين الصحابة رضي الله عنهم . ץ- تركهم القطع بوعيد الفساق من أهل القبلة فصاحب الكب الكبيرة مؤمن ب- ب- إهمال قيمة العمل بفصله عن الإيمان ع- إنكارهم الشفاعة لان الكبائر لا تضر بالإيمان العمان وحيئذ لا فائدة في الشفاعة.

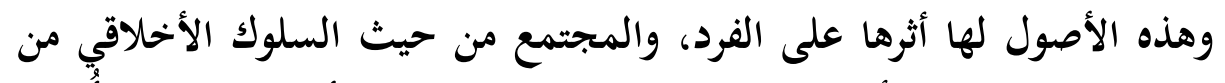

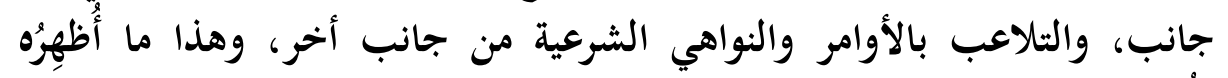

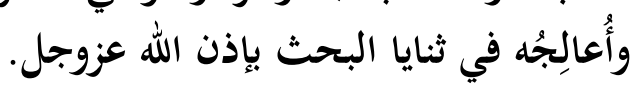

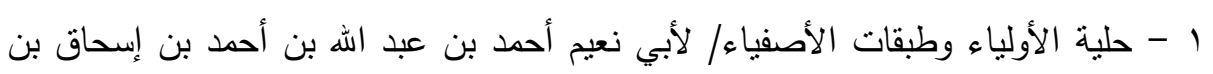

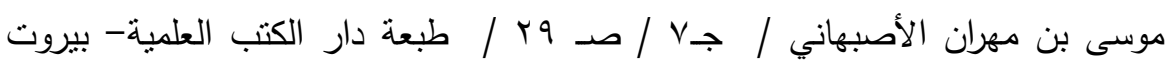




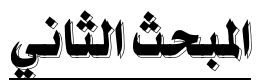

\section{رأيهـم في حقيقة الإيهان وملاقتهل بالأخلاق ومناقشتهيه}

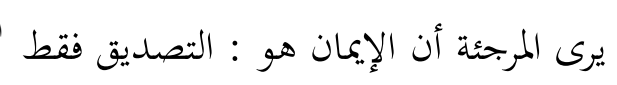

وقيل هو (الإيمان في القلب الإن هو : التصديق فلططان، وهو المعرفة باللَّه تعالى، والمحبة والخضوع له بالقلب) آلخان

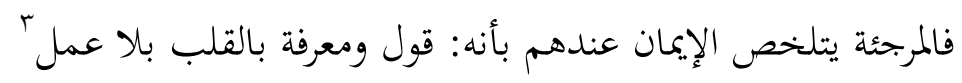

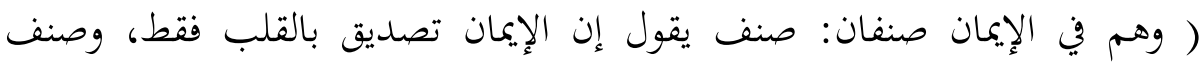
يقول: الإيمان قول باللسان وتصديق بالقلب، وغلا منهم مغالون فقالوا: هو الإقرار

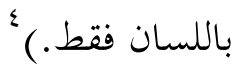

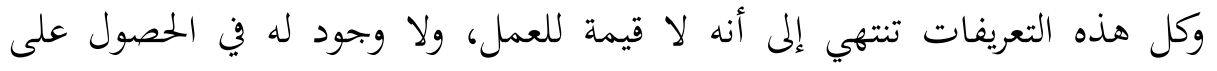

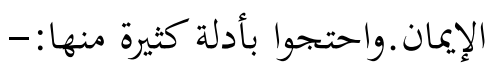

من أدلة المرجئلة

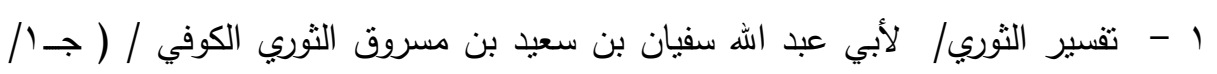

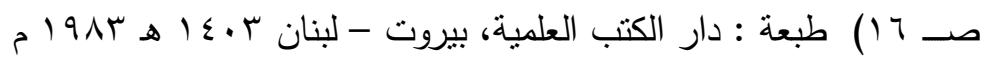

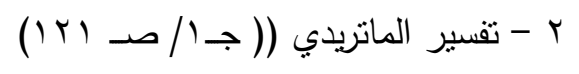

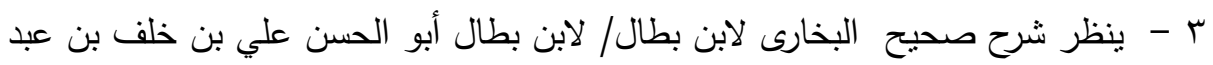

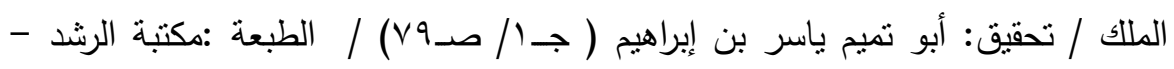

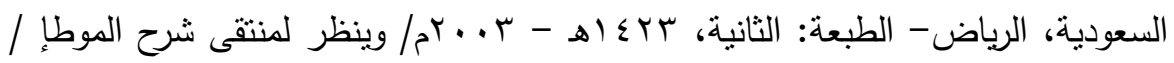

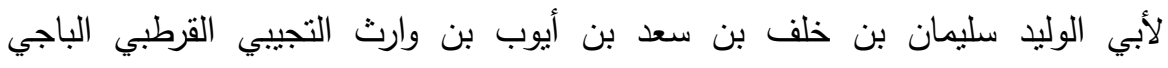

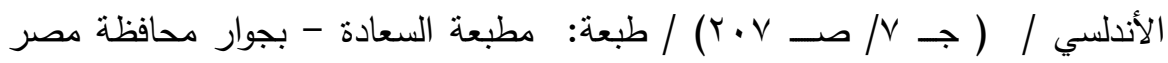

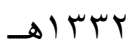
ع - طالع الأنوار على صحاح الآثار /لإبراهيم بن يوسف بن أدهم الوهراني الحمزي، أبو إنها

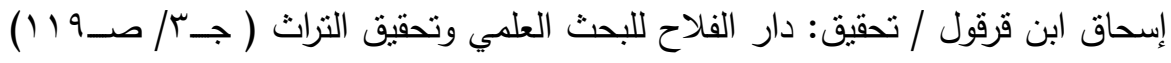

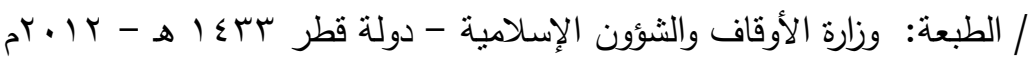


مارواه مسلم بسنده عن عباده بن الصامت قال:( سمعت رسول الله صلى الله عليه

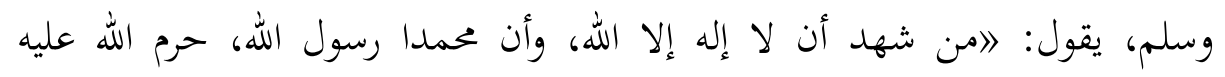
النار)

وبناء على تعريفهم بأن الإيمان هو التصديق أو المعرفه أو الإقرار باللسان قالوا بأن إنان

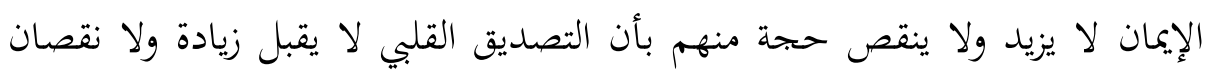

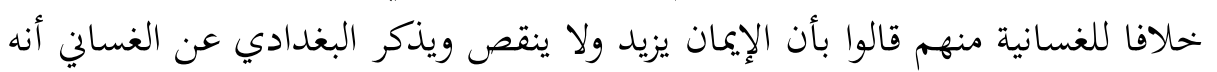

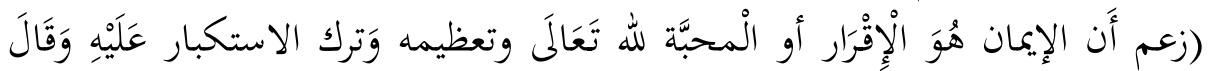

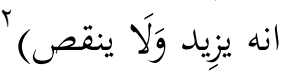

تبين أن المرجئة يزعمون أن بندان الإيمان هو المعرفة والتصديق القلبي ،أو النطق

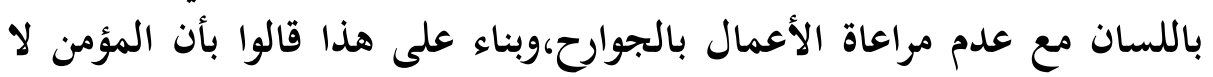

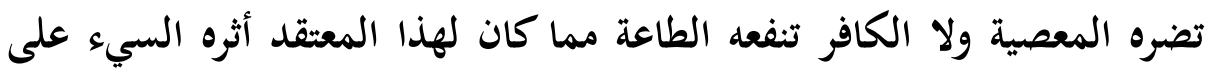

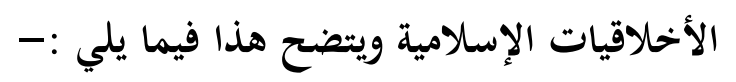

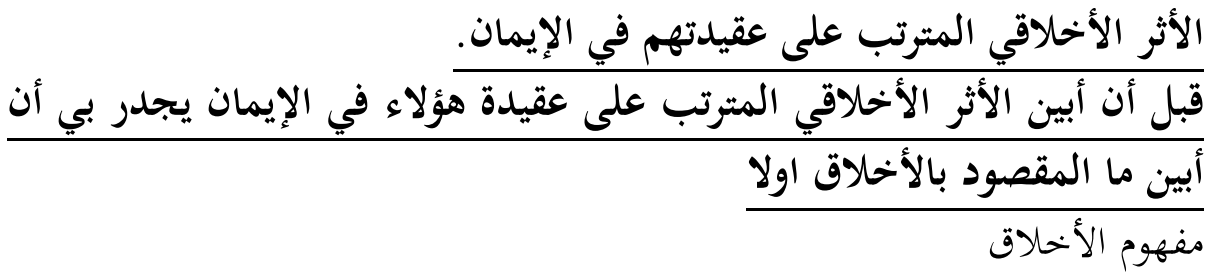

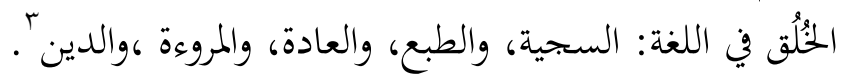

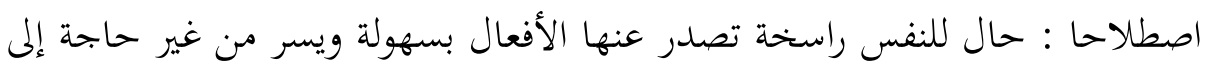
فكر ورؤية.

| - صحيح مسلم / كتاب الإيمان / جـ/ / صـ اNم/ حديث رقم (10)

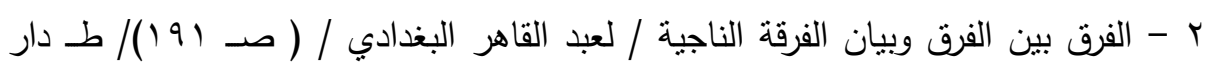

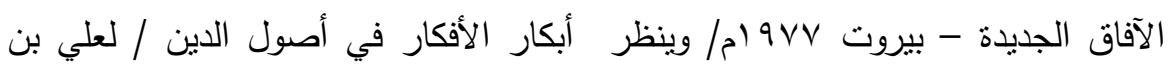

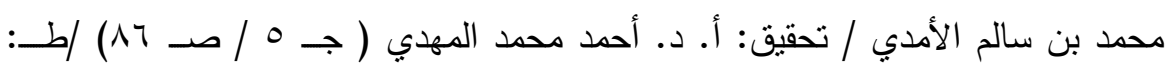

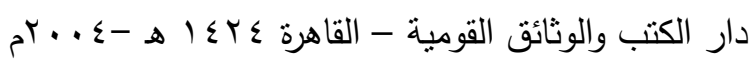

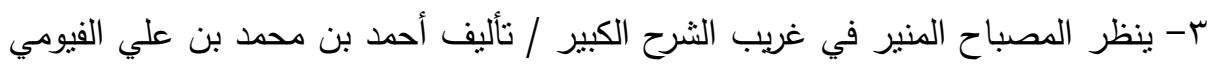

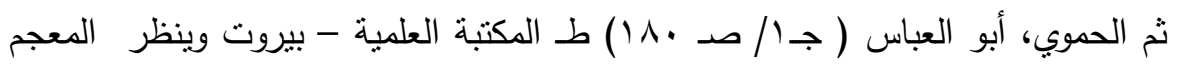

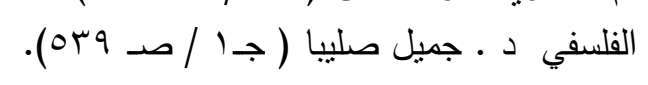

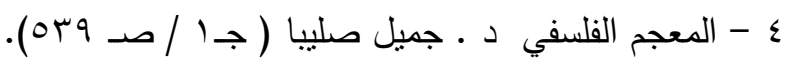


ثمرة الأخلاق

مما لا شك فيه ولا ريب أن علم الأخلاق له ثمرات وفوائد جمة من أهمها:

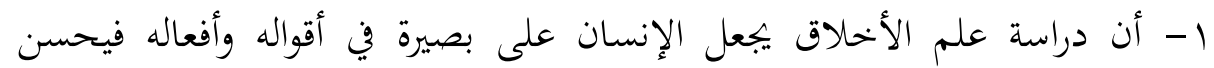

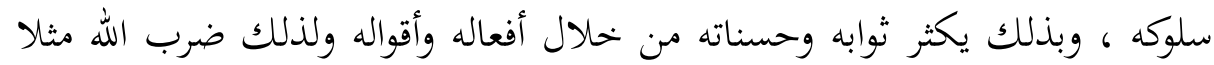

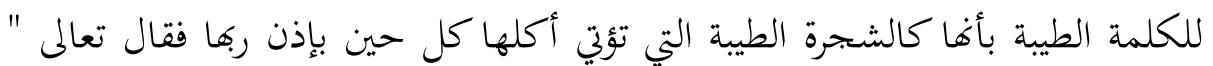

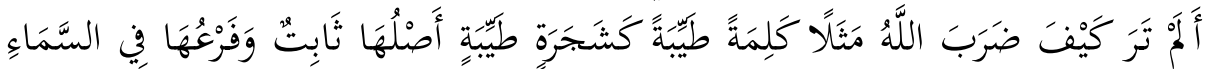

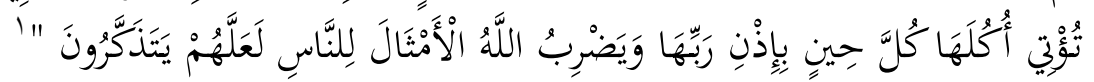

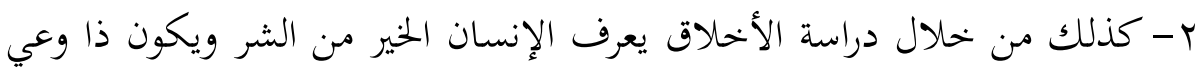

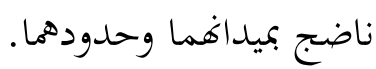

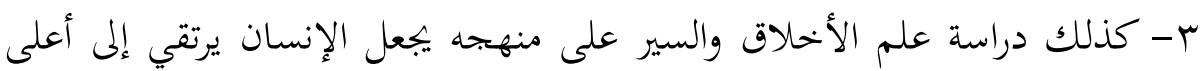

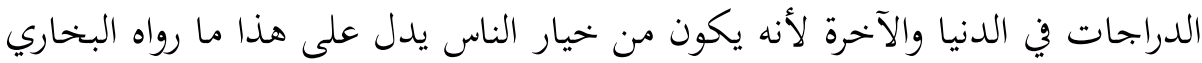

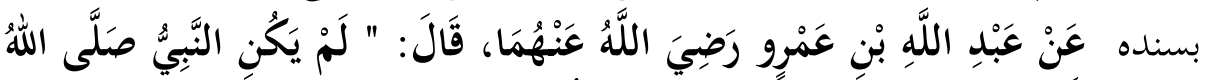

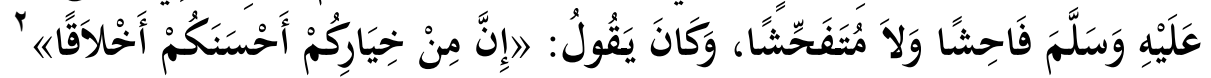

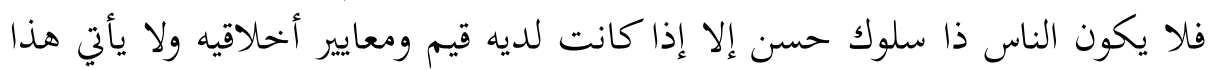

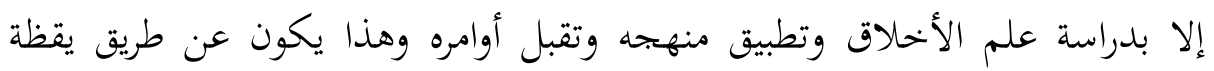

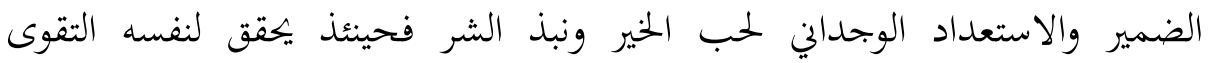

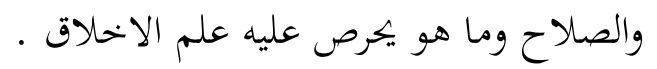

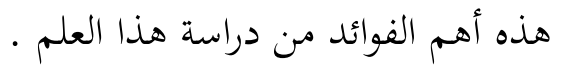

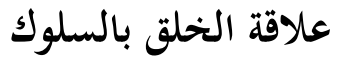

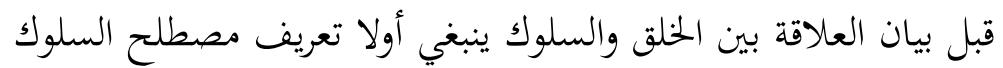

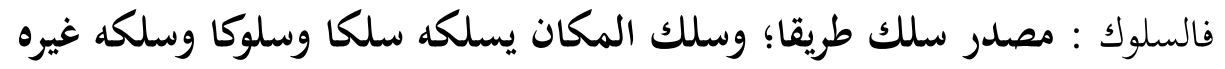

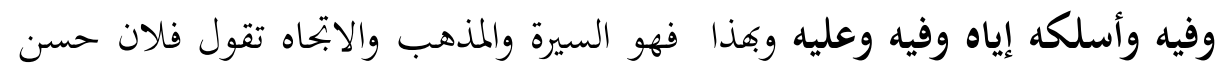

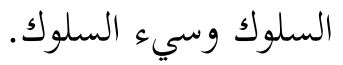

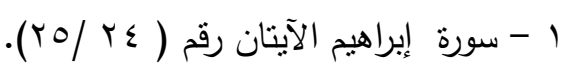

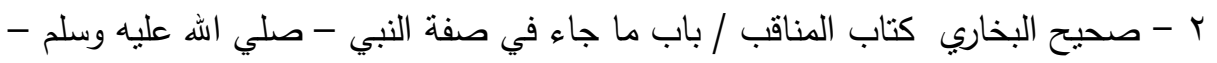

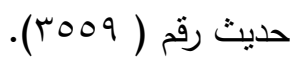




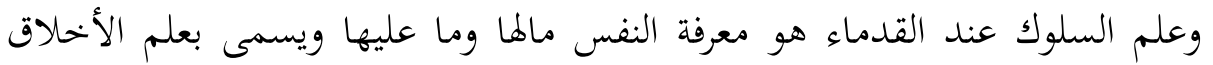

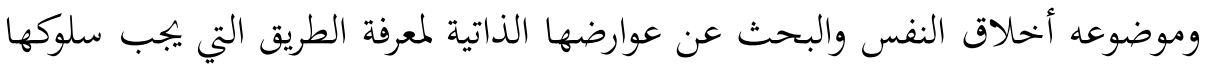

توجد علاقة وطيدة بين الخلق والسلوك فالخلق سجية داخلية لا تظهر إلا عن طريق

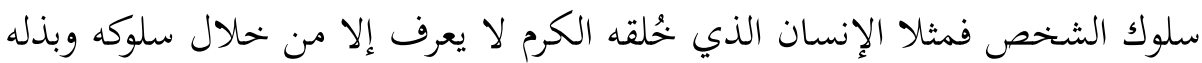

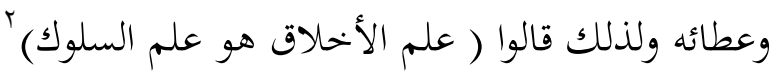

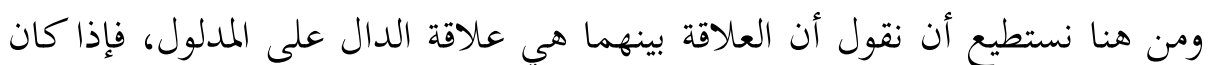

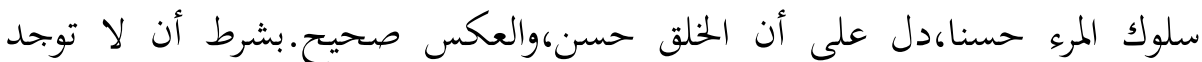

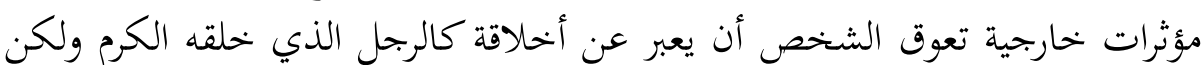

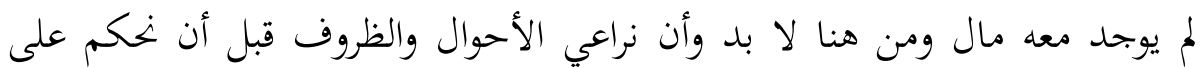

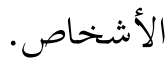

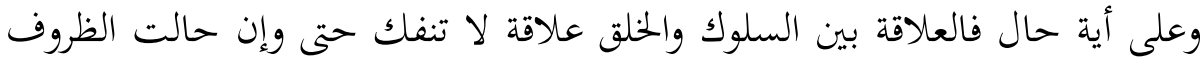

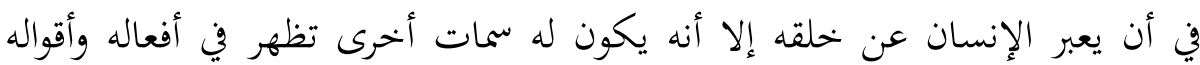

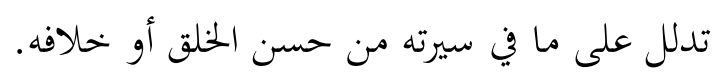

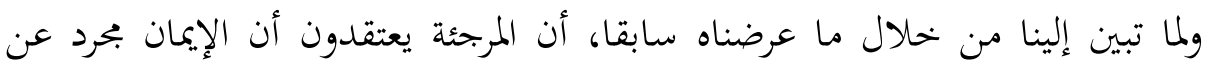

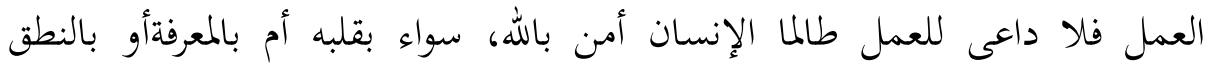

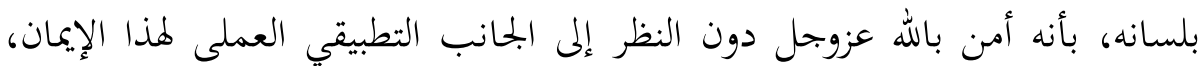

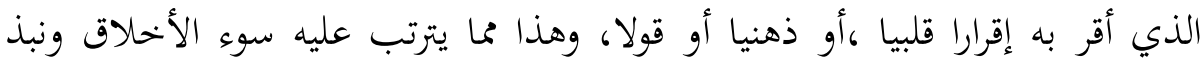

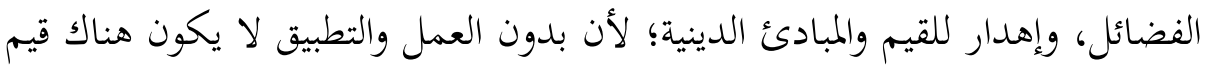

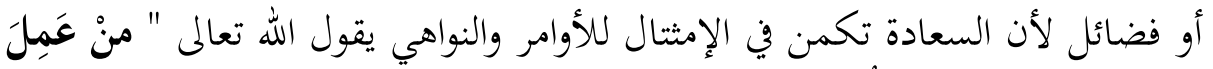

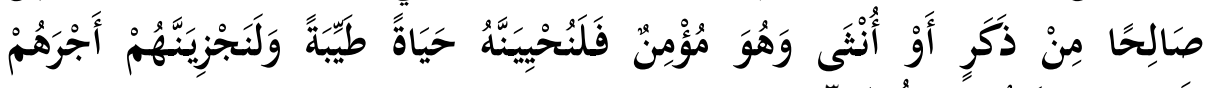

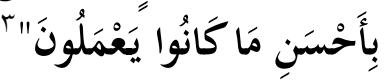

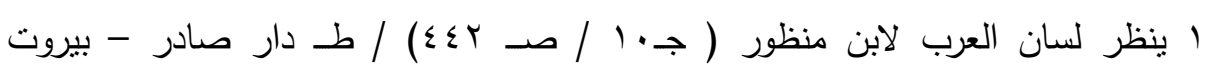

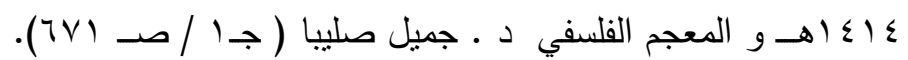

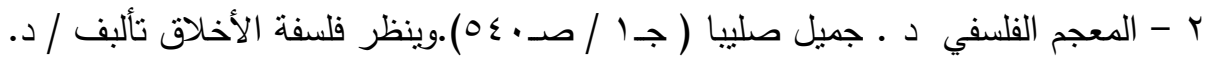

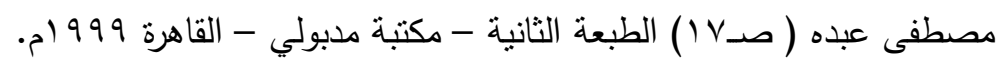
r - سورة النحل الآية رقم ( (9V) 
وهكذا قال الفلاسفة حيث ربطوا السعادة الأخلاقية في الحرص على التطبيق العملى (

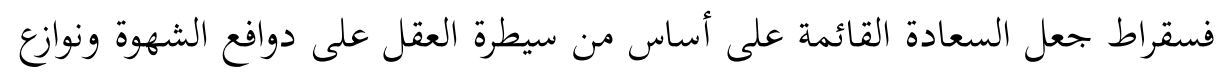

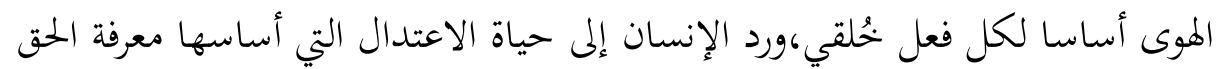

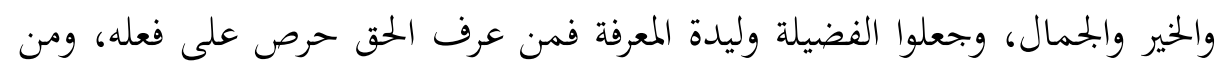

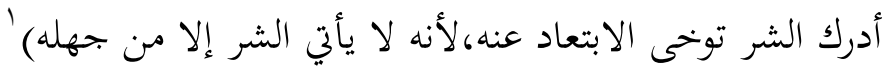

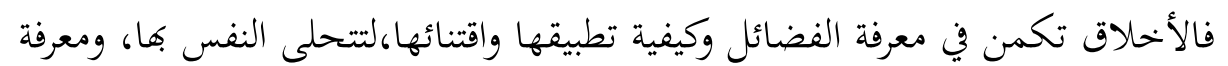

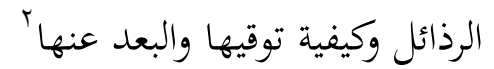
وبناء على هذا فإن ( مفكري الإسلام على اتفاق في إقامة المبادئ الخلقية على وأساس أساس

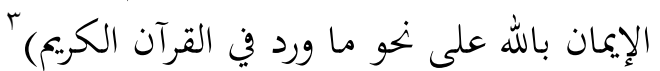

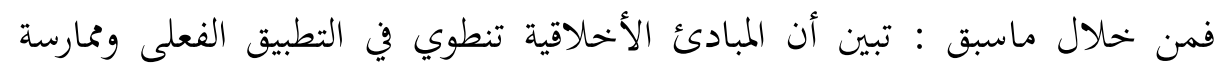

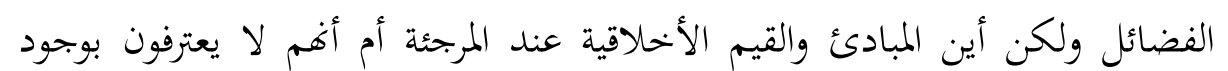
أخحلاق أصلائ ونكن لا أجد ردا غير إني أقول بناء على منهجهم في الإيمان فإن سلوك الإنسان ليس ذي

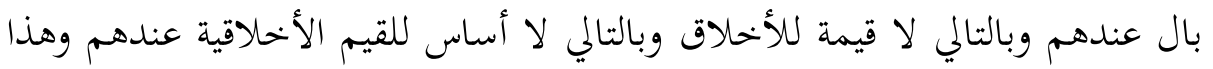

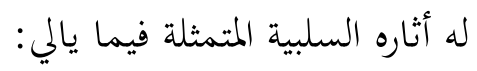

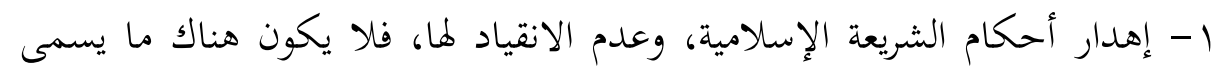

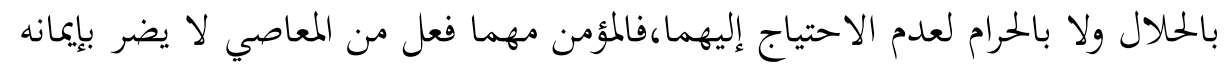

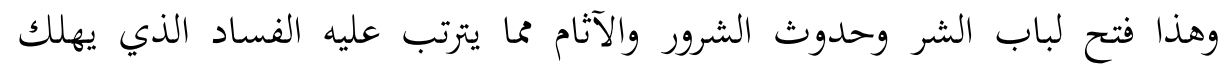

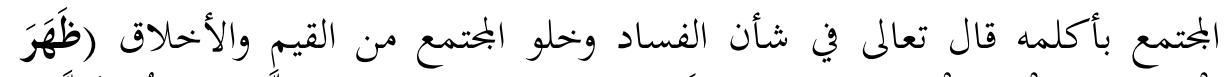

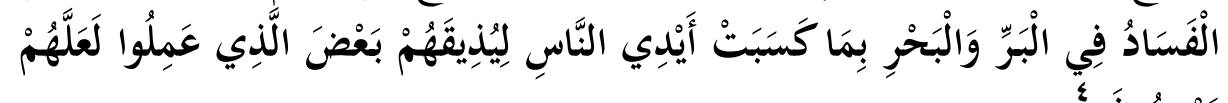

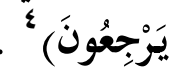
ب - ضياع سنة النبي صلى الله عليه وسلم المتمثلة في التطبيق العملى للشريعة الإسلامية

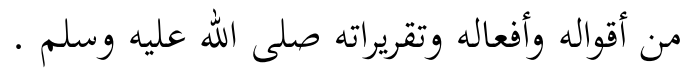
1 - مشكلة الخير والثر في الفكر الإسلامي أصولها - تطبيقاتها / دكتور محمد السبد

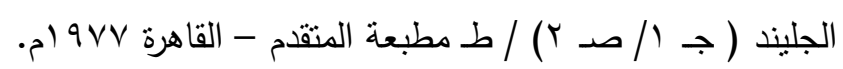
r - فلسفة الأخلاق نشأتها وتطورها / د نوفيق الطويل ( صـ ـ ـ 1 (1) بتصرف.

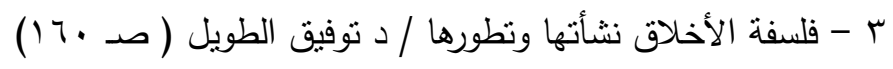

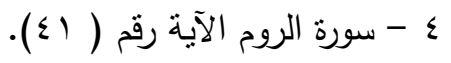


فلو كل إنسان قال آمنت بالله تعالى أو صدق بقلبه ثم اكتفى بهذا ولم يطبق إيمان هذا

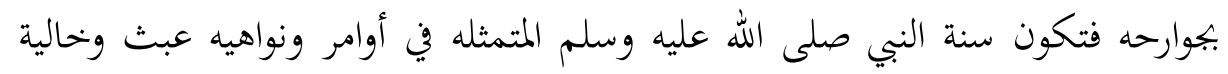

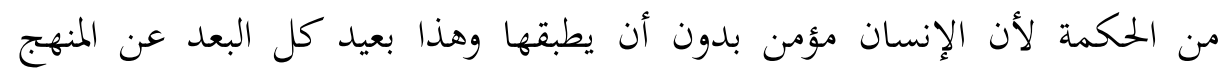

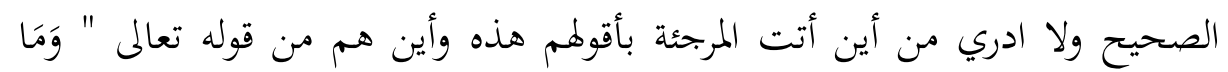

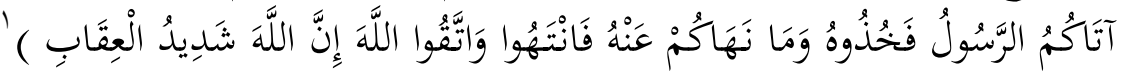

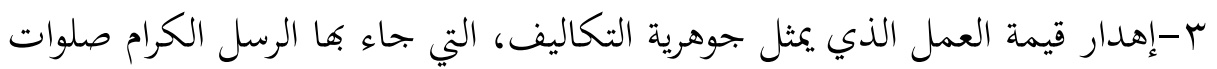

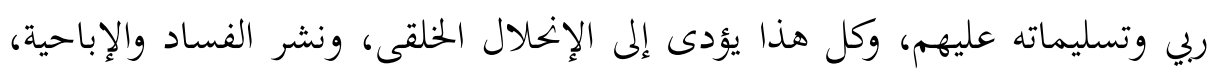

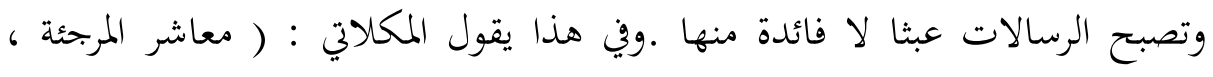

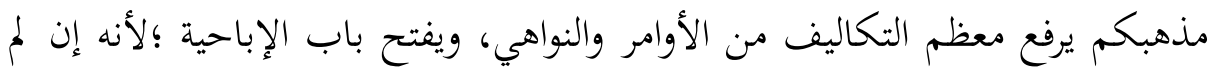

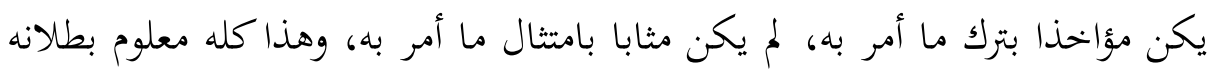

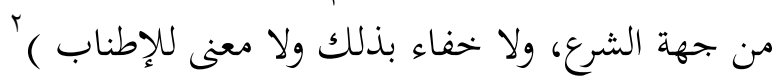

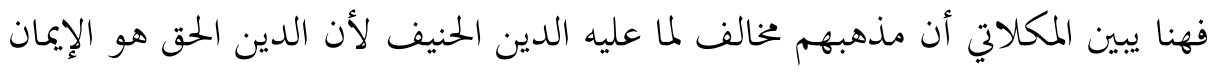

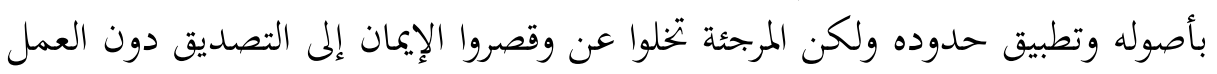

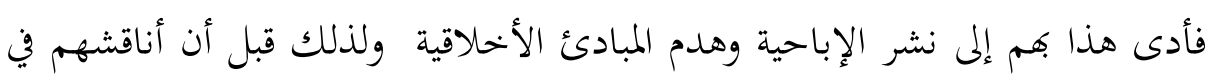

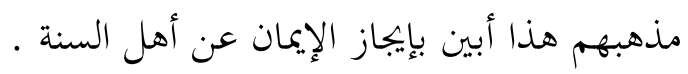

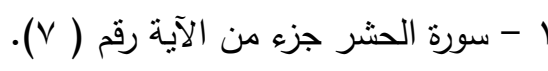

r - الككلاتي ( صـ (qهن). 


\section{الإيمان عند أهل السنة}

الإِيمان عند جمهور الأشاعرة هو التصديق سواء في اللغة أو الشرع ـ( قُلْلًَا الْإِيمَان هُوَ

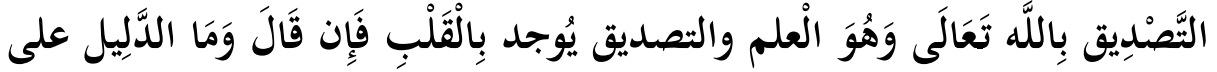
مَا قُلْنْمْ

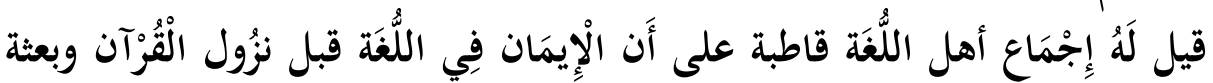

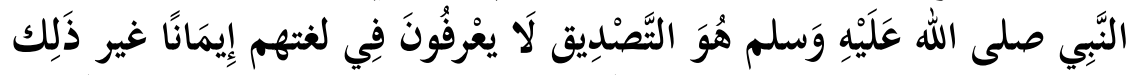

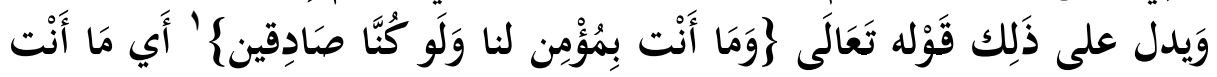

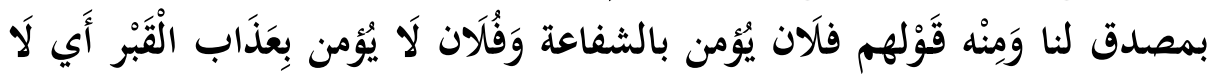

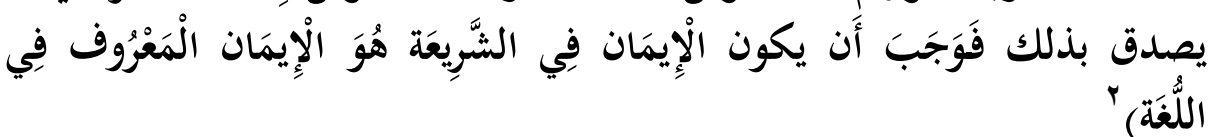
ويقول الشهرستاني في بيان عقيدة الأشعري في الإيمان (الإيمان هو النصديق

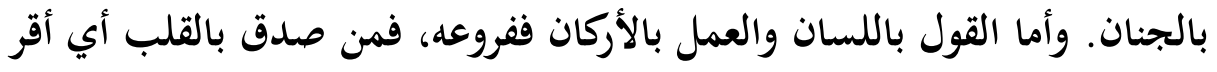

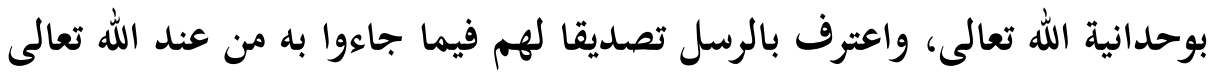

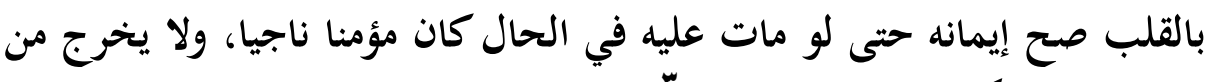
الإيمان إلا بإنكار شيء من ذلك ألك.

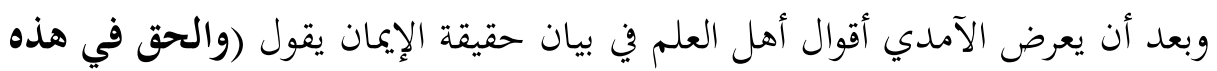

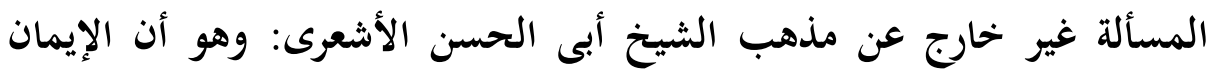

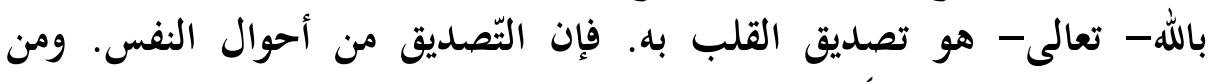
ضرورته المعرفة شرعا)

1 - سورة يوسف جزء من الآية رقم (lV).

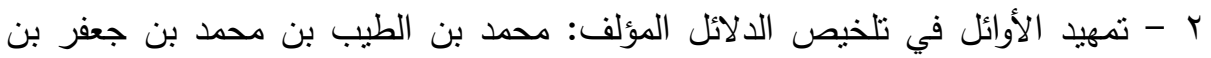

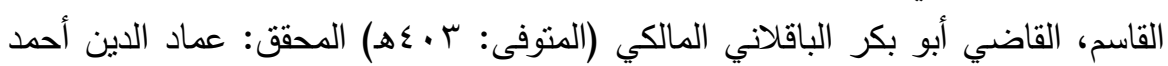

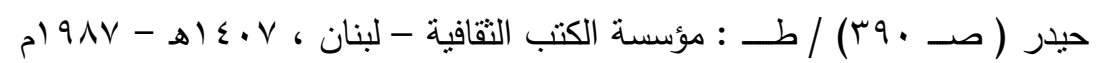

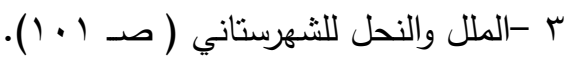

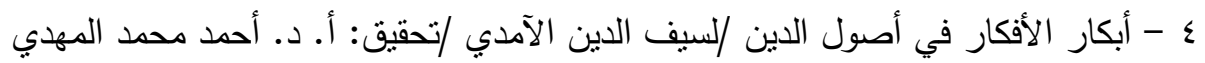

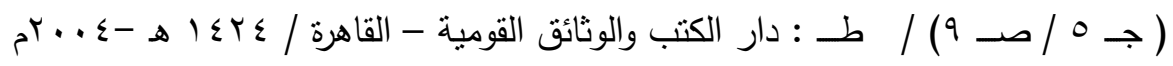


ولبيان أن الأشاعرة يقرون بشرطية العمل وأنهم لا يهملونه (فعلمنا انتفاء التّصديق عند وجود هذه الكبائر سمعا)'

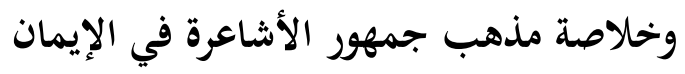
1 أن ألإيمان الثرعي: هو الإيمان المعروف في الإنان اللغة وهو التصديق

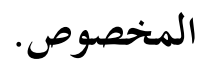
r و ـ أن التصديق محله القلب فقط، بدليل الآيات التي تنسبه إليه دون غيره، .

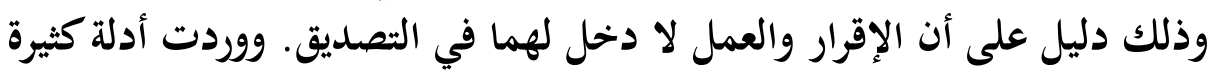

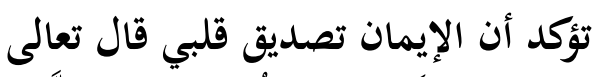

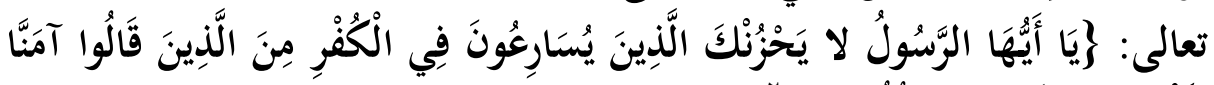

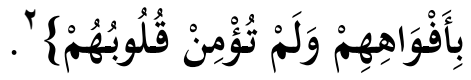

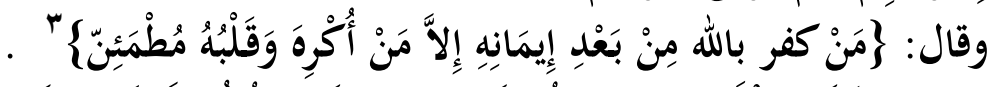

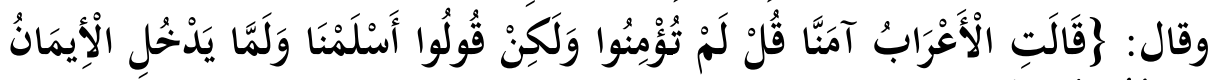
فِي قُلُْوبكُمْ

r ـ ـ أن العمل خارج عن الإيمان ومغاير له، بدليل عطف العمل على العلى الإيمان

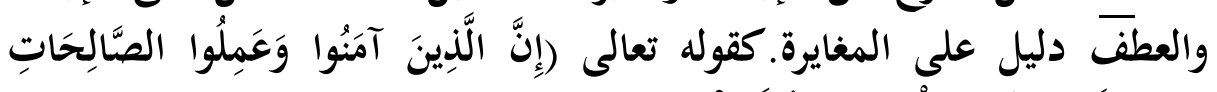

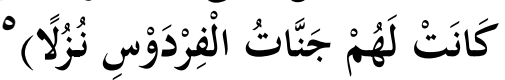

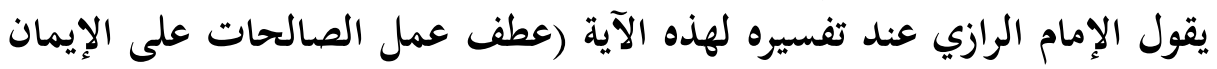

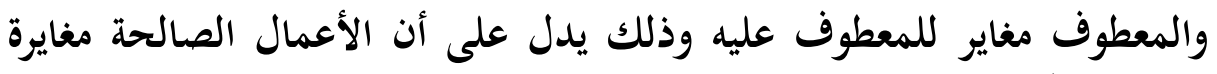

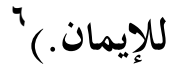
ع ـ أن القرآن الكريم ولغة العرب، والإجماع، تدل على بقاء الإيمان على أصله اللغوي.

$$
\begin{aligned}
& 1 \text { - أبكار الأفكار في أصول الدين ( جـ م / صـ } 9 \text { (1) ) }
\end{aligned}
$$

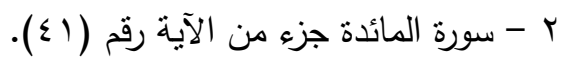

$$
\begin{aligned}
& \text { r - سورة النحل جزء من الآية رقم ( } 1 \text { - (1). } \\
& \text { ع - سورة الحجرات جزء من الآية رقم (ع (1). } \\
& \text { ه - سورة الكهف الآية رقم (V) • (1). }
\end{aligned}
$$

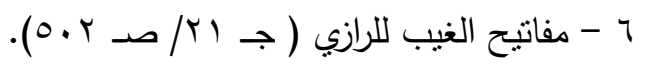

MrA 
ه- ـ أن الإقرار والعمل شرط في الإيمان، يلزم الإتيان بهما، ومَن فَّط فيهما فهو معَّرض للعقاب.

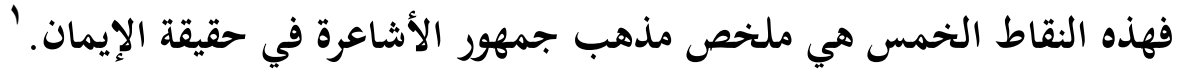

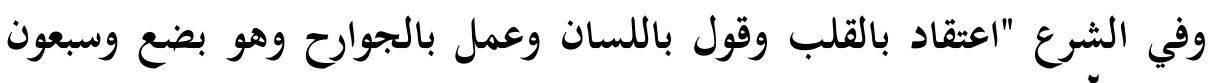

فالسلف قالوا: هو اعتقاد بالقلب، ونطق باللسان، وعمل بالأركان، وأرادوا بذلك الألك

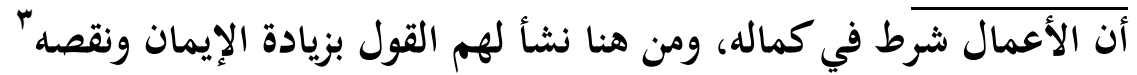

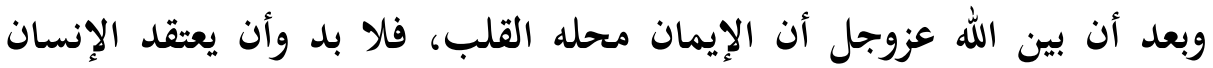

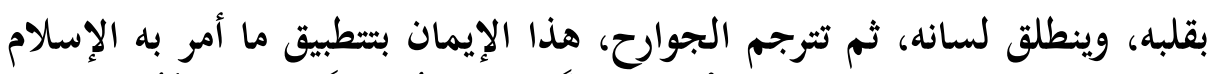

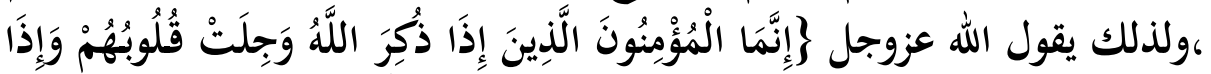

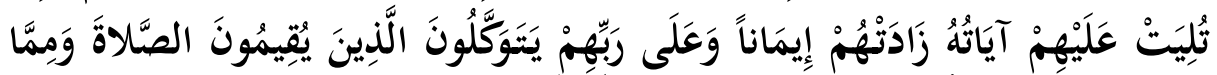

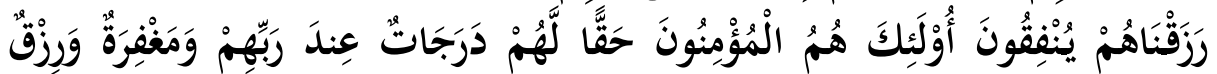
كَرِيمُ ؛

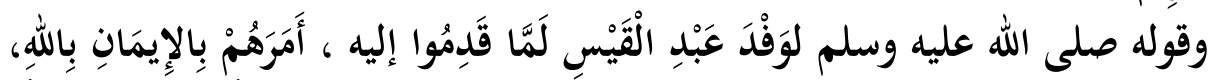

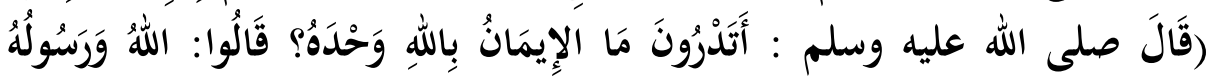

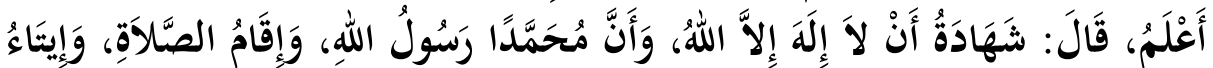

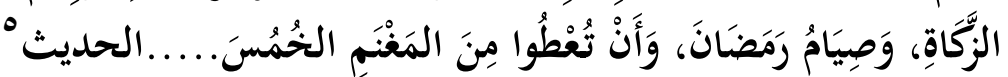

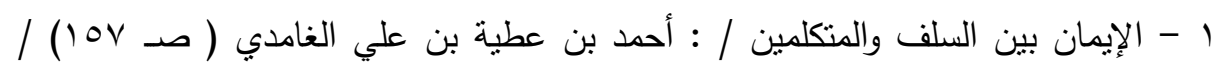

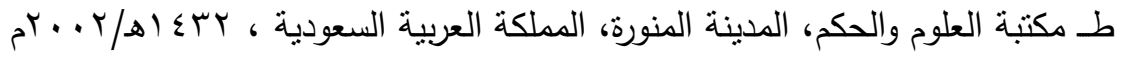

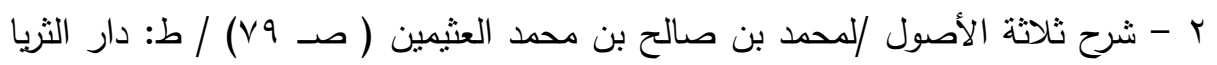

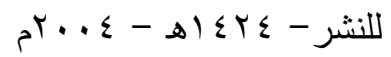

r - لوامع الأنوار البهية وسواطع الأسرار الأثرية لثرح الدرة الدضية في عقد الفرقة المرضية

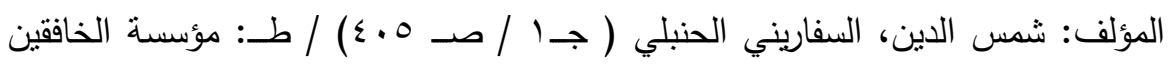

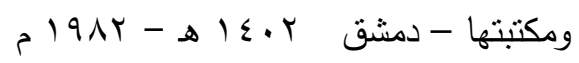

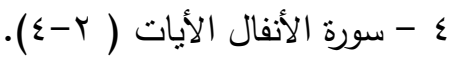

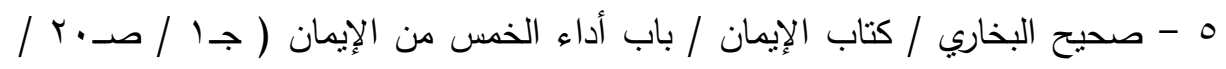

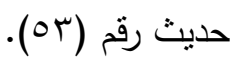




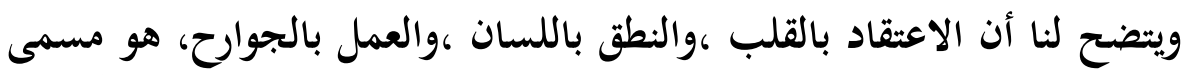

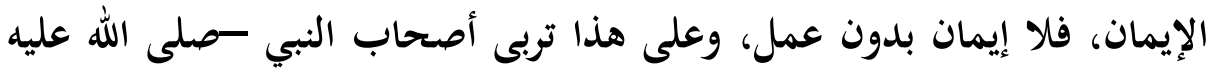

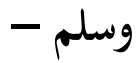

والخلاف بين أهل السنة الأشاعرة وغيرهم خحلاف لفظي فسواء من عرف الإيمان

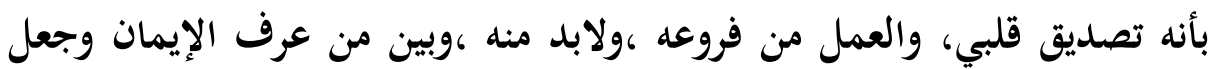

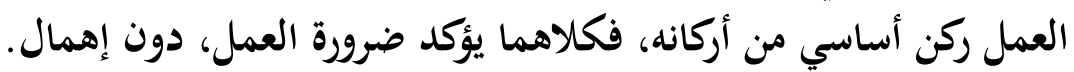

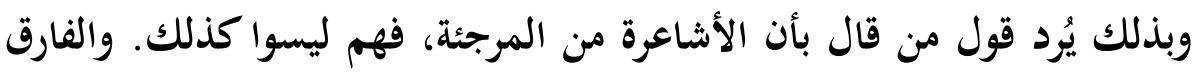
لا يخفى على ذوي الألباب.

( فالعمل له عندهم مكانة كبيرة، فتاركه أو تارك شيئ منه يكون مذنباً معرَّضاً

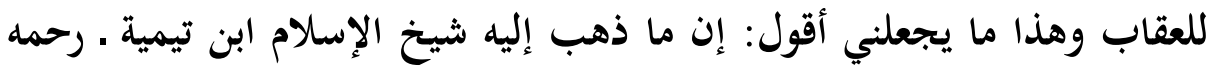

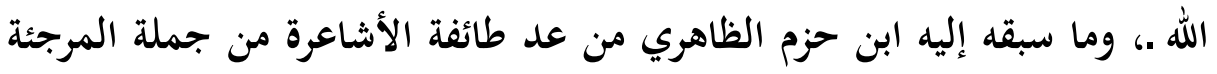

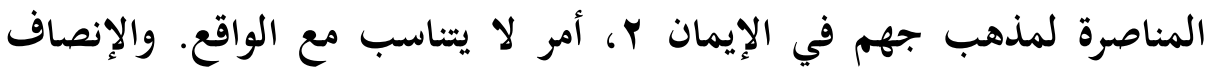

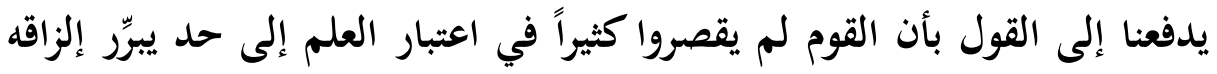

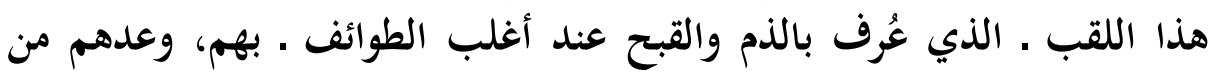

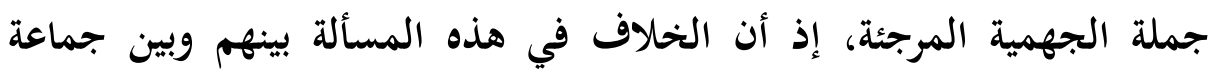

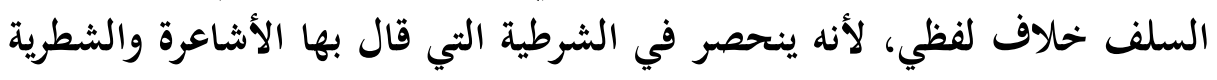

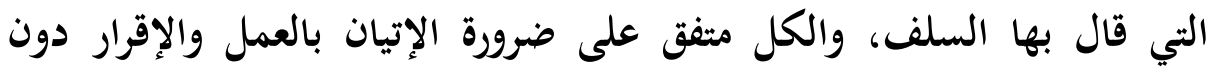

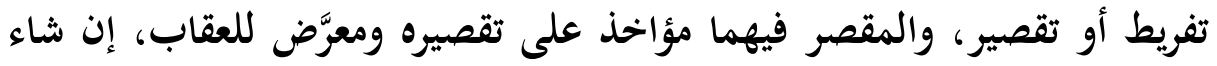

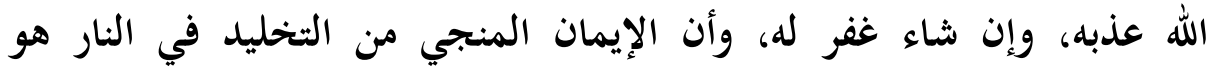

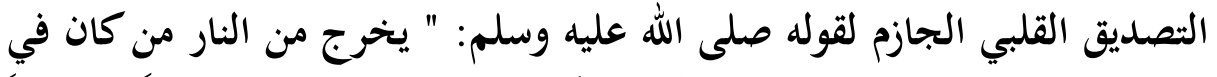

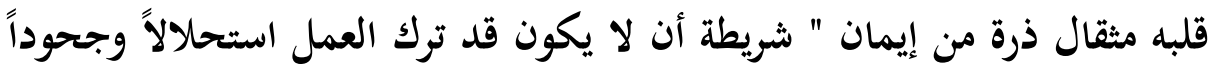

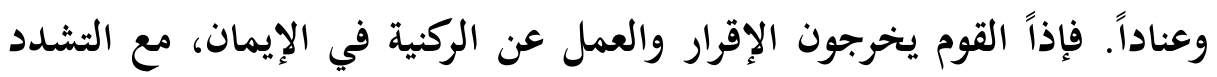

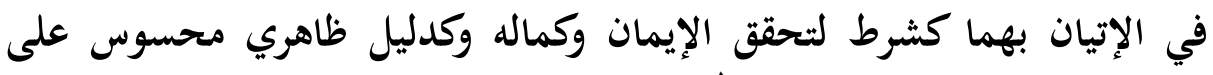

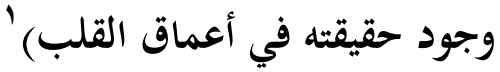

1 - الإيمان بين السلف والمتكلمين / : أحمد بن عطية بن علي الغامدي ( صـ ror). 
وبناء على ذلك فِإنً:

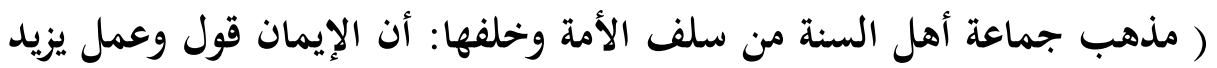

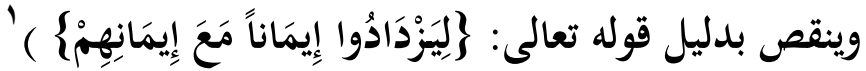

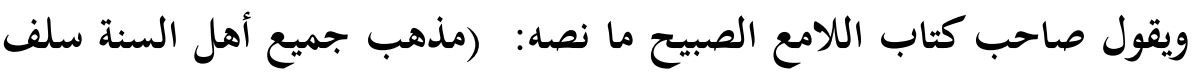

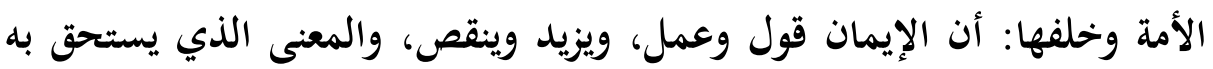

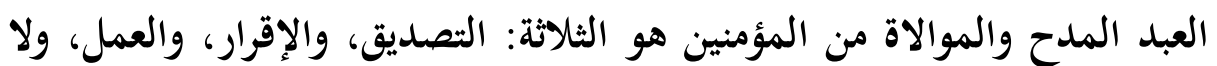

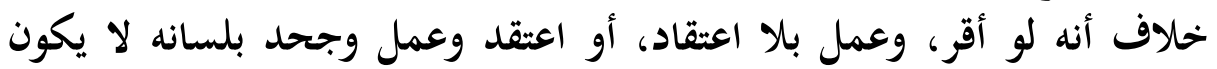

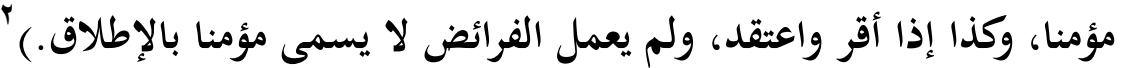

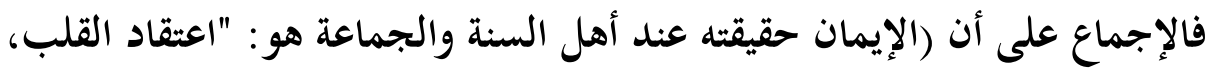

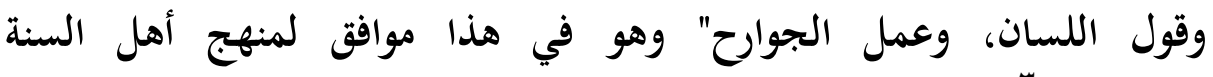
والجماعة.) وقول السان،

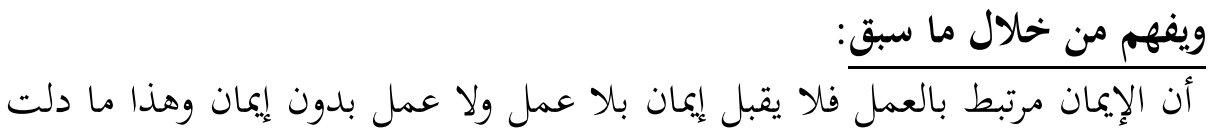

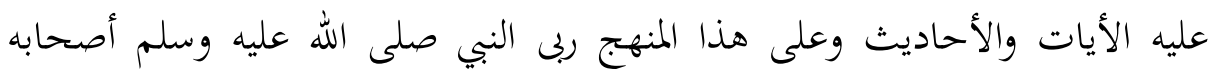

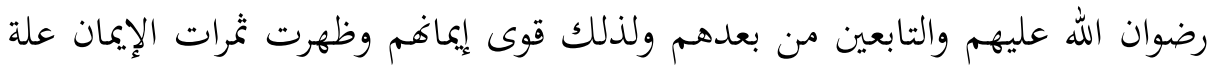

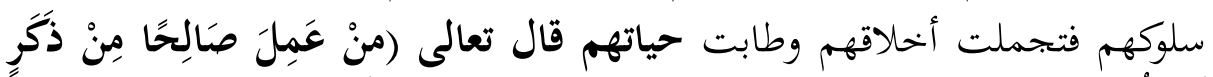

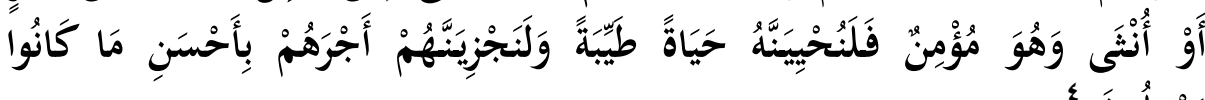
يَعْمَلُونَ)

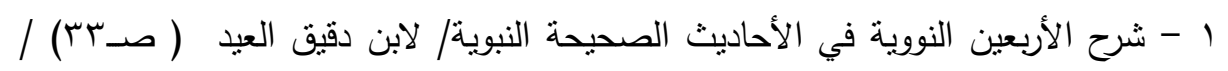

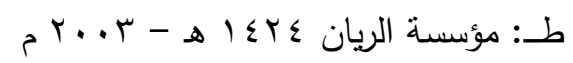

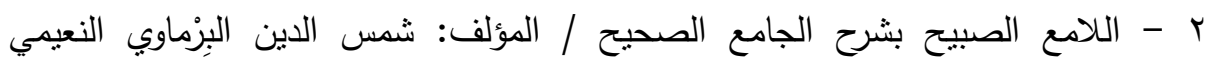

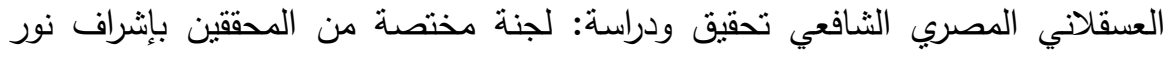

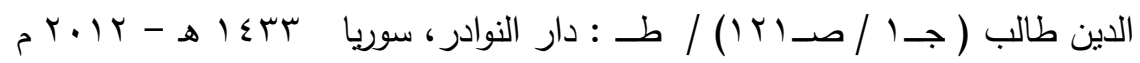

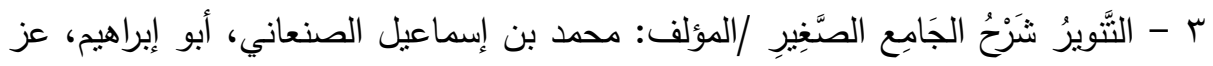

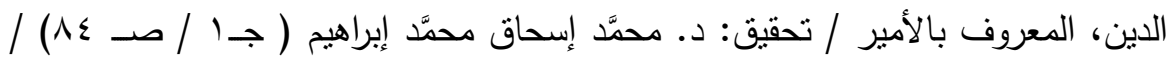

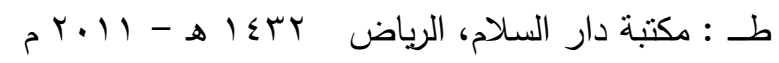

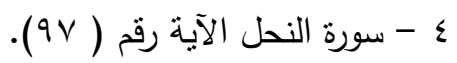


وبعد عرض موقف أهل السنة من الإيمان أناقش المرجئة فيما ذهبوا إليه في قولهم في الإيمان وأثره الأخلاقي.

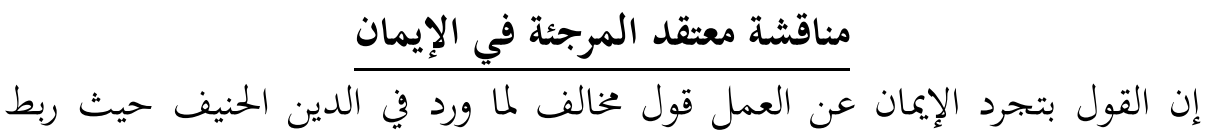

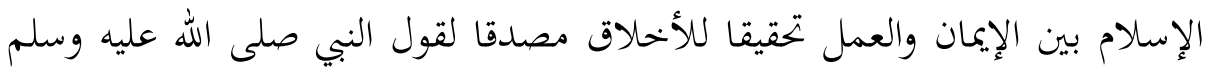

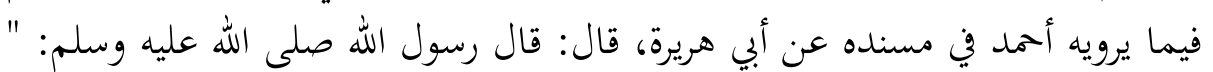

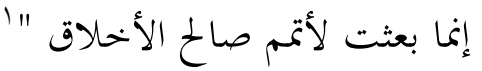

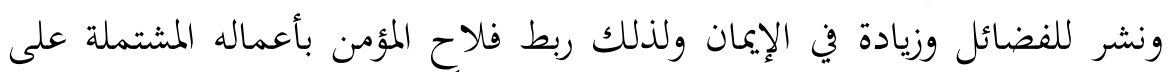

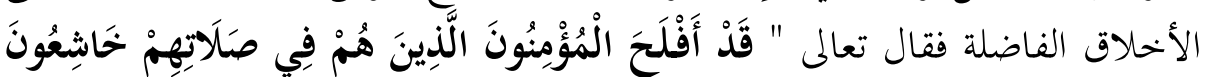

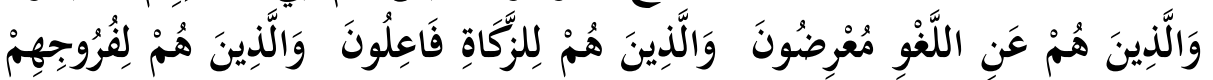

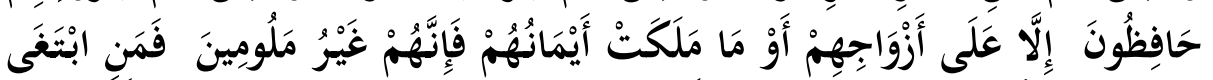

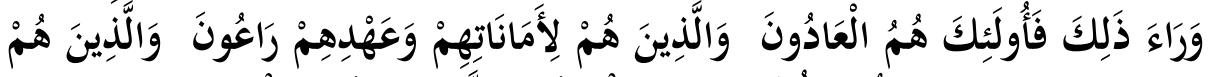

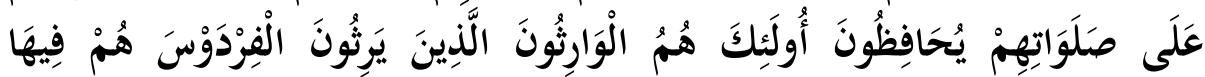

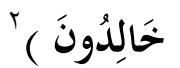

... فالشريعة الإسلامية ترسخ الدعائم الرئيسة للأخلاق، وهي ما جبلت الضعاق عليها

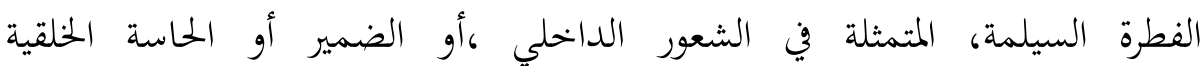

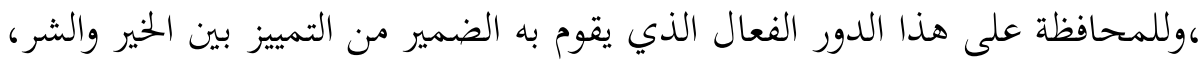

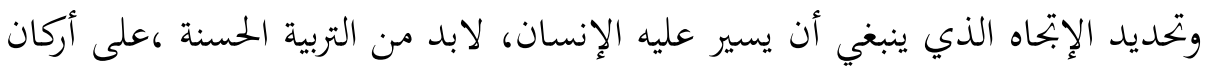

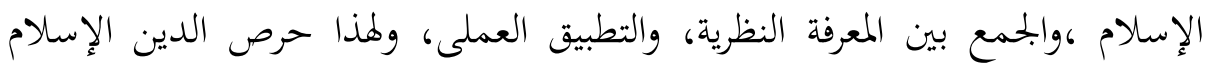

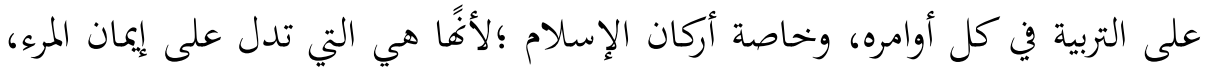

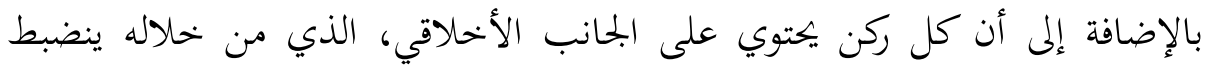

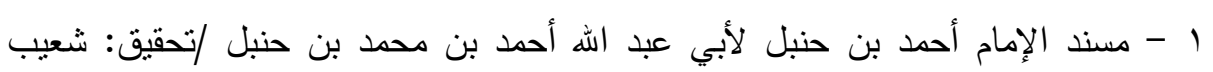

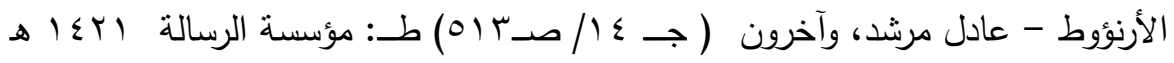

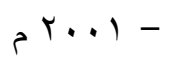
r - سورة المؤمنون من الآية رقم ( إلى رقم 1) 
السلوك الإنساني، حني يرتقي بصاحبة ،إلى أعلى الدرجات في زيادة الإيمان، وجسن أخلاقة ،وسلوكه. ولبيان ذلك يتضح في الأتي: أولا : شهادة التوحيد ( شهادة أن لا إله إلا الله وأن محمدا رسول الله صلي الله عليه وسلم) الله تبارك وتعالي فطر الناس على الدين الحق وهو الاستسلام والإنقياد للعبادة الله الله

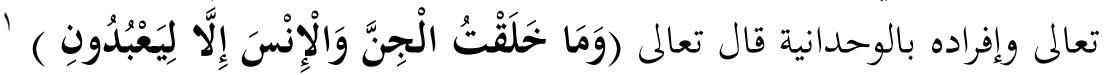

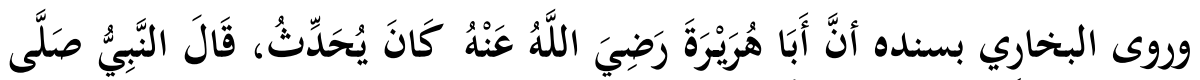

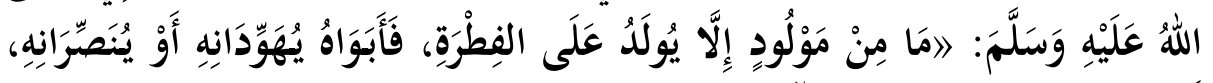

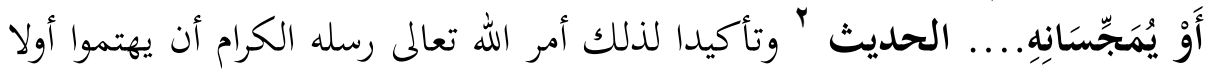

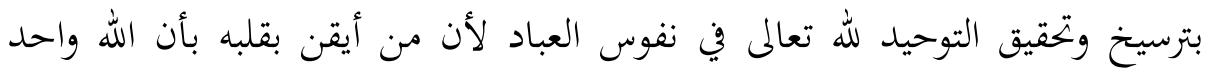

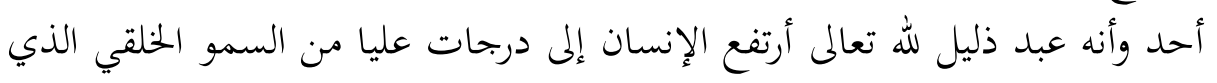

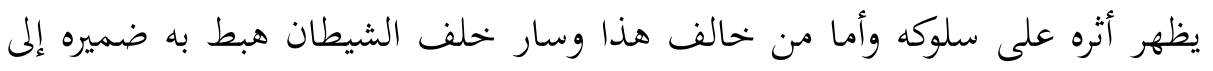

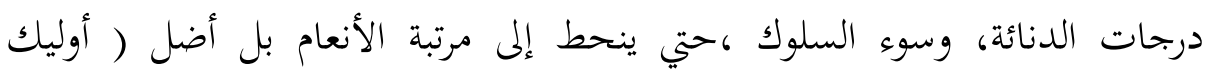

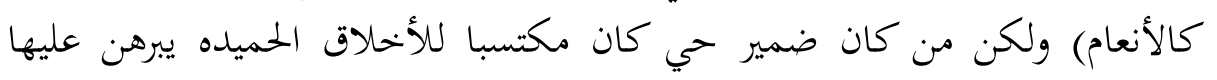

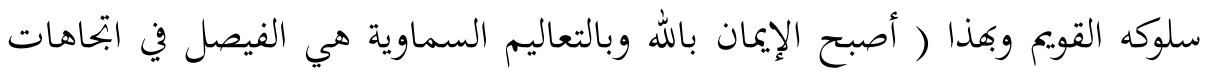

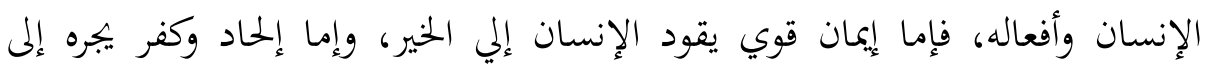

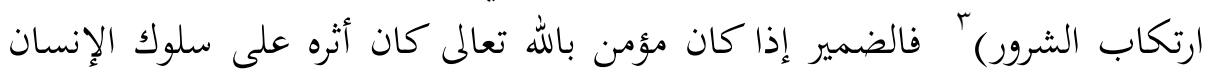

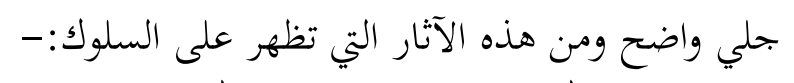

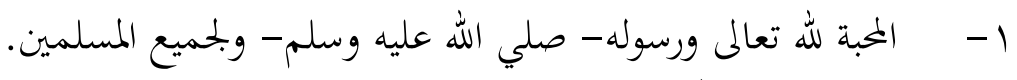

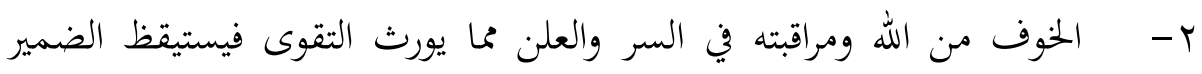

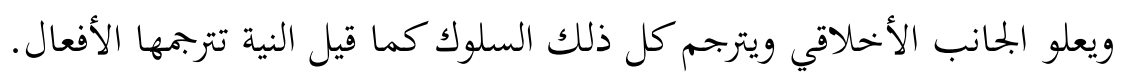

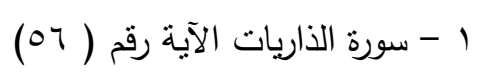

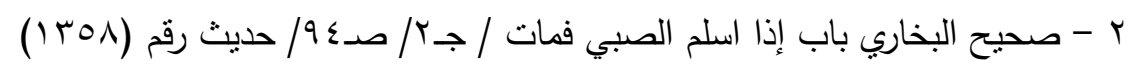

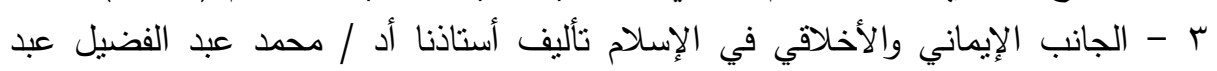

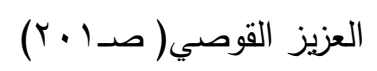


ثانيا : إقامة الصلاة

الصلاة هي ركن ركين فهي عماد الدين ،والحبل المثين بين العبد وربه إذا أقمها الإنسان

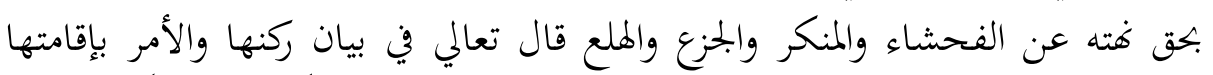

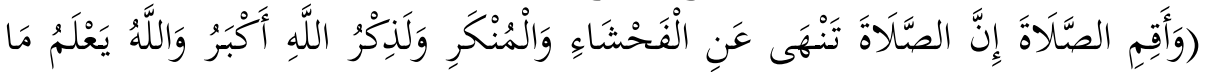

'تَصْنَعُونَ)

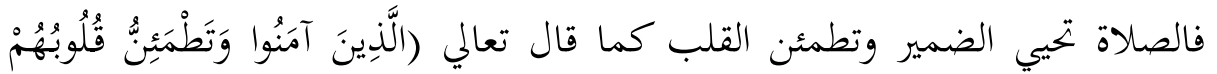

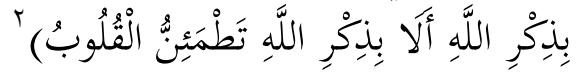

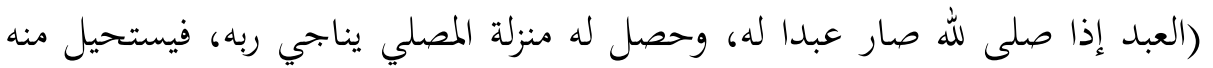

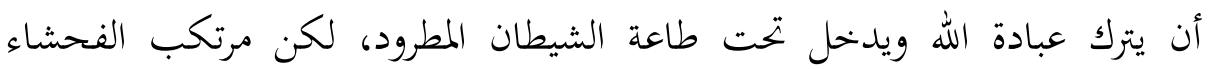

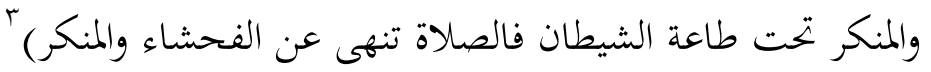

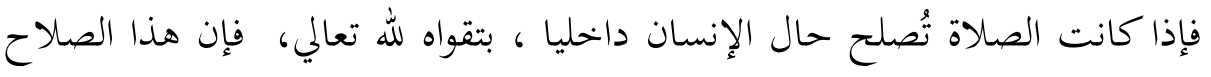

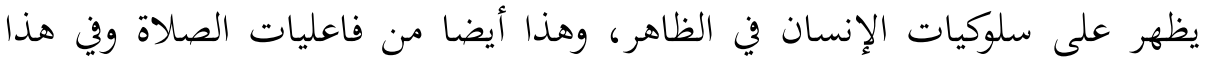
يقول الإمام الرازي (واعلم أن هيئة الصلاة هيئة فيها هيبة فإن أولها وقوف بين يدي الله كوقوف المملوك

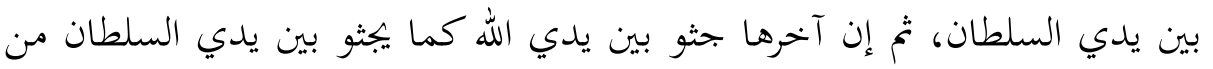

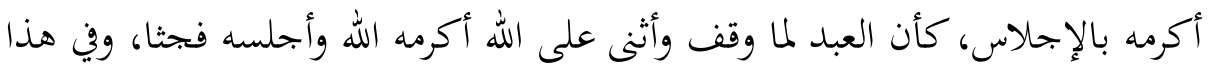

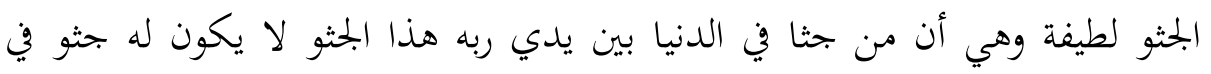

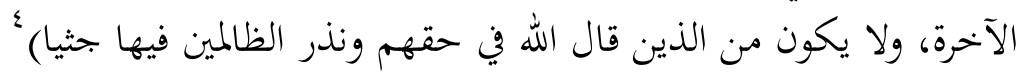

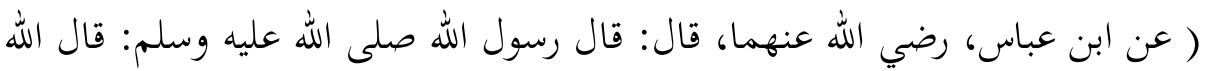

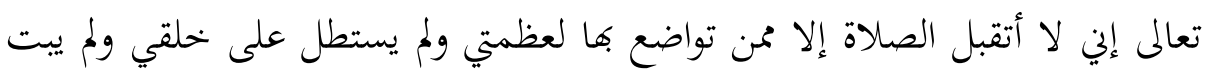

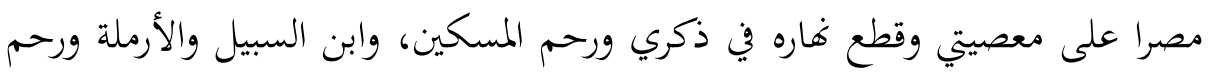

1 - سورة العنكبوت جزء من الآية رقم ( 1 (؟).

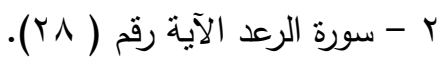

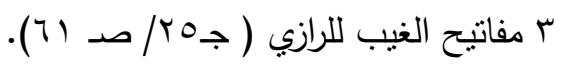

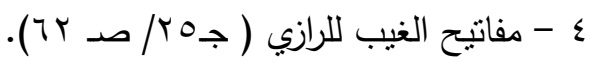


المصاب ذلك نوره كنور الشمس أكلؤه بعزي وأستحفظه ملائكتي وأجعل له في الظلمة

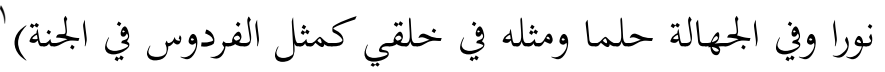
ثالثا: إيتاء الزكاة

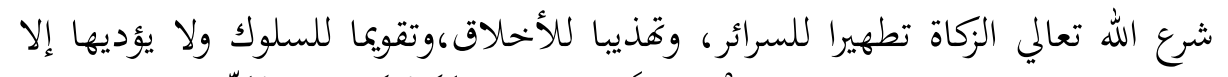

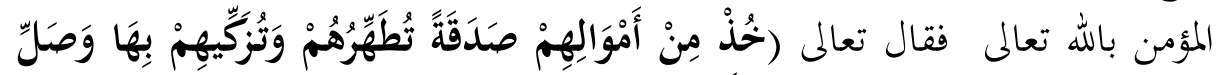

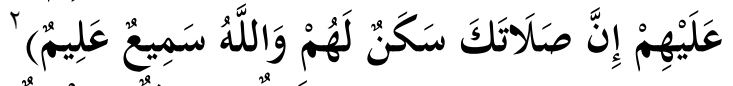

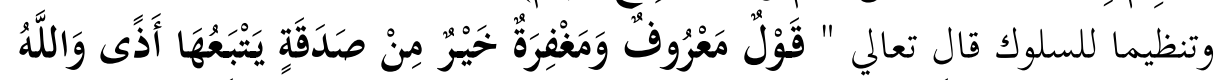

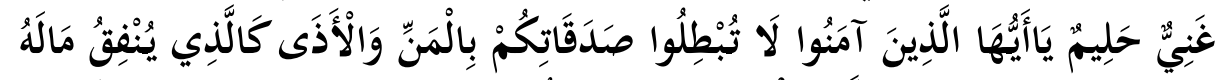

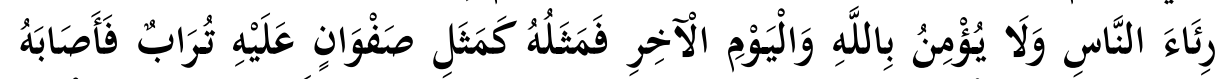

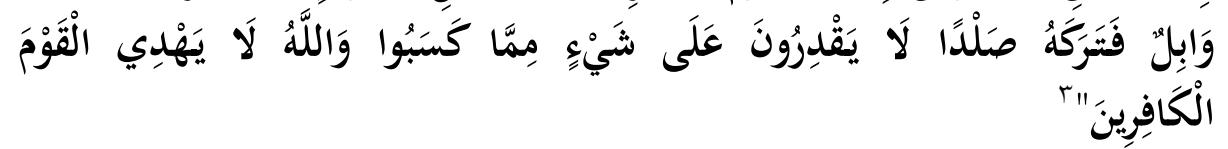
فهنا ترشِنا الآيات أن أيتاء الزكاة علامة على إيمان المرء فهى طهارة لنفسه وماله وأما

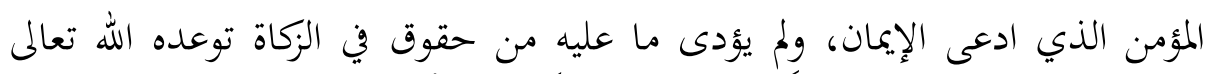

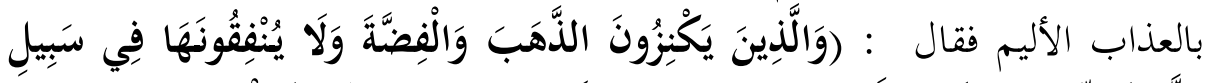

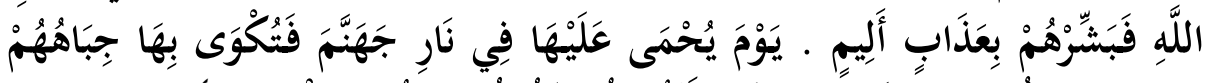

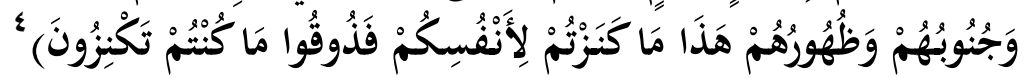

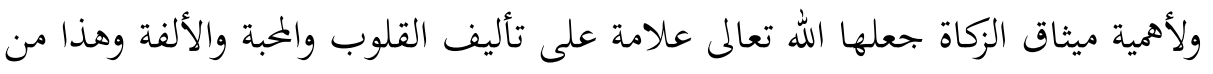

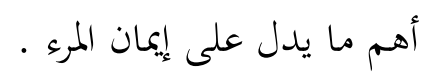

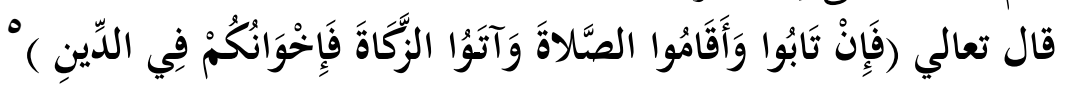

1 - مسند البزار المنشور باسم البحر الزخار / لأبي بكر أحمد بن عمرو بن عبد الخالق بن (الني

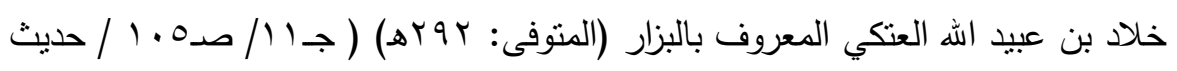

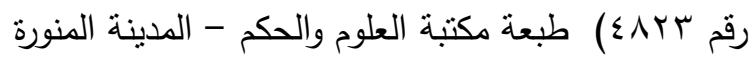

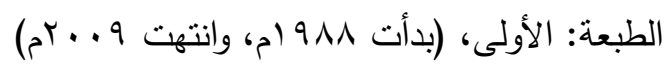

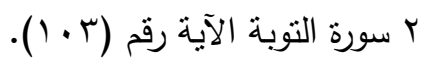

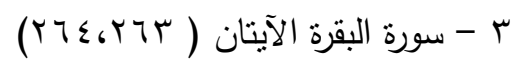

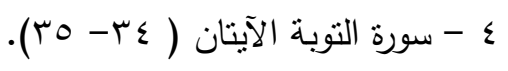
ه - سورة التوبة جزء من الآية رقم (1) (1). 


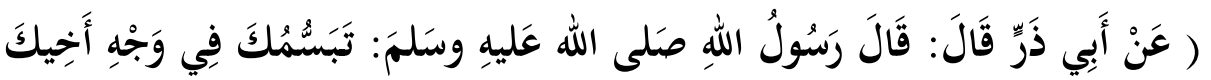

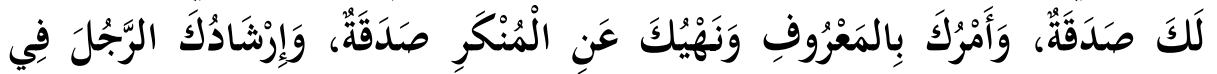

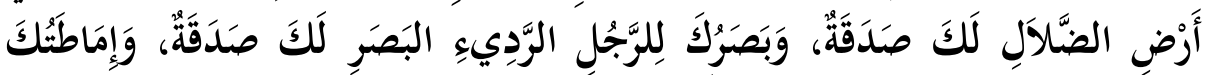

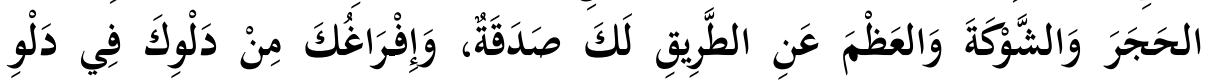
'أَخِيكَ لَكَكَ صَدَقَقَّة.

رابعا : صوم رمضان

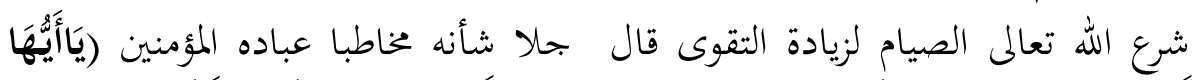

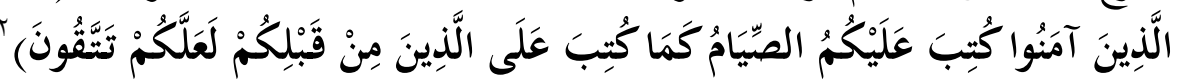

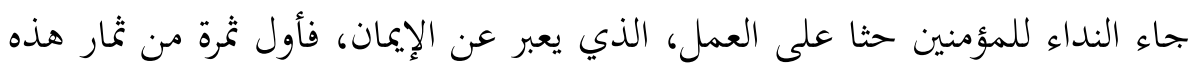

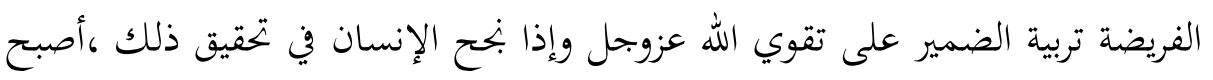

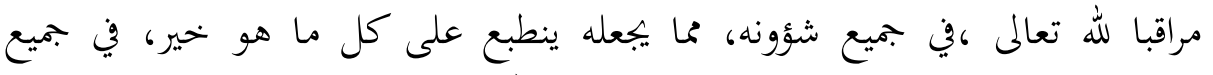

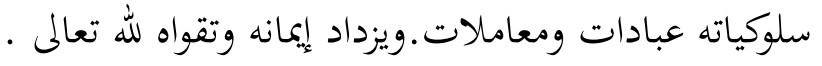

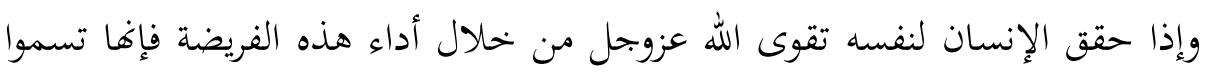

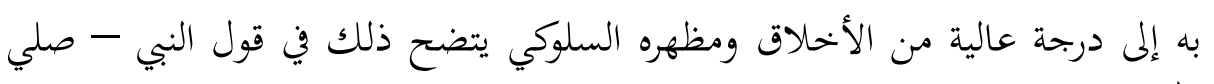

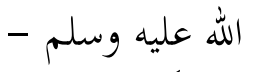

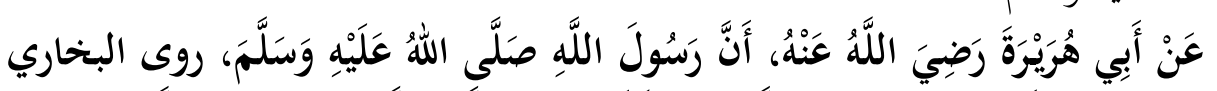

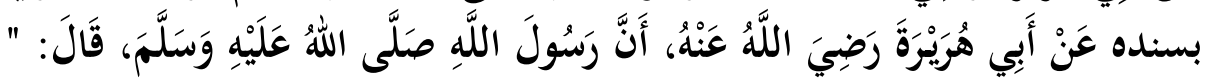

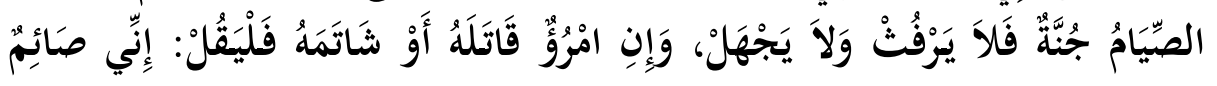
$"$

فالصيام وقاية وحجاب عن المعاصي والشهوات ؛لأن قلب الصائم الحقيقي يكون

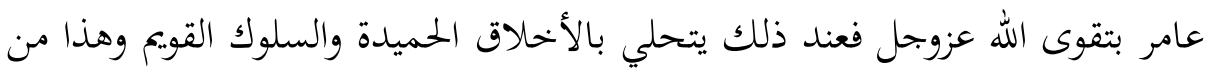

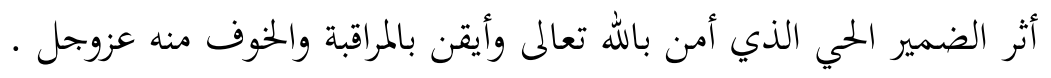

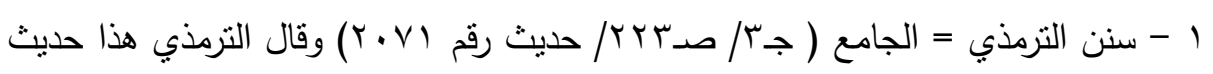

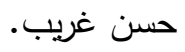

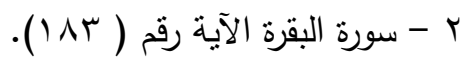


فهذه الأركان تشتمل على الأعمال الظاهرية والباطنية وبتنفيذها يُحسن الإنسان

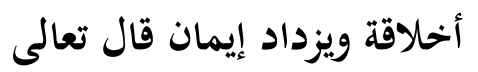

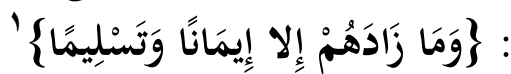

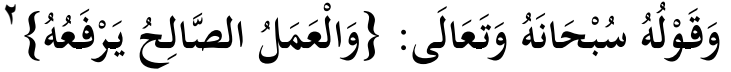

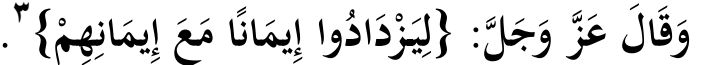
وَقَالَ جَلَّ ذِكْرُهُهُ:

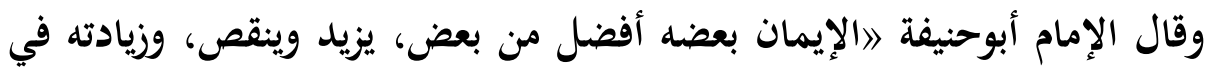

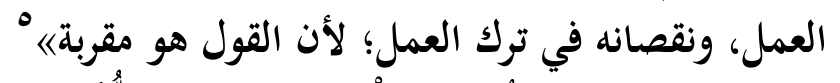

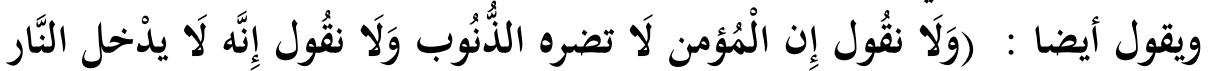

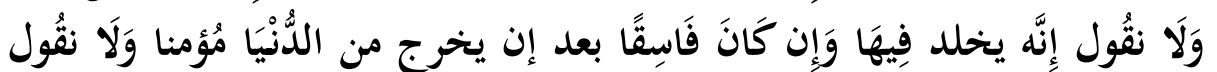

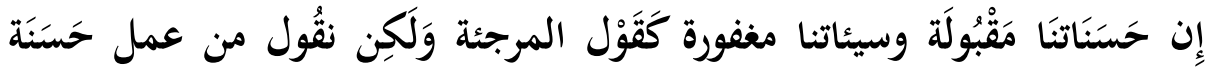

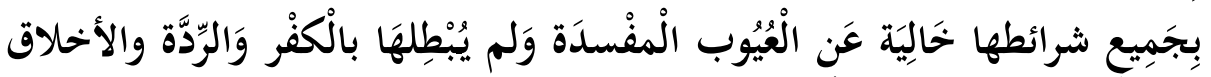

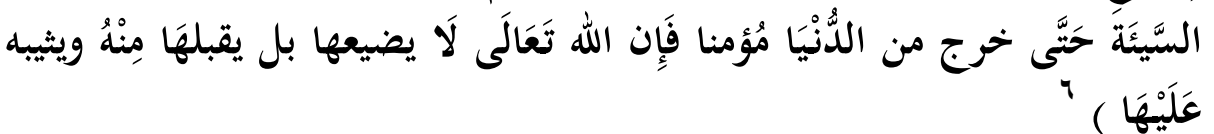
وهذا هو الدين الإسلامي الذي ارتضاه الله تعالى لعباده (فاعلموا رحمنا وإياكم

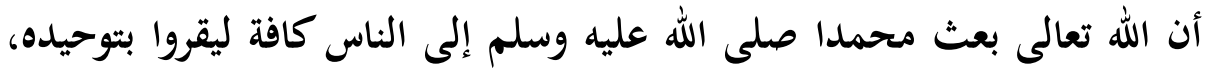

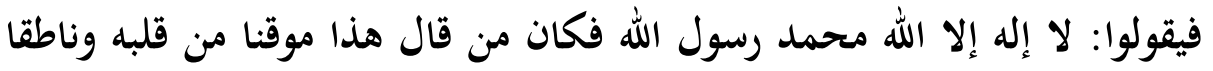

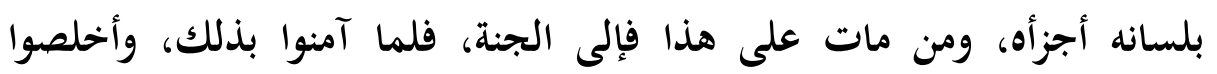

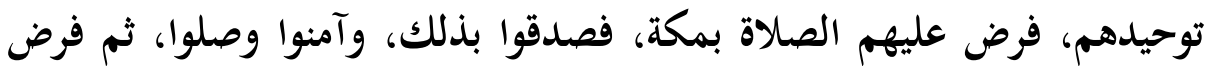

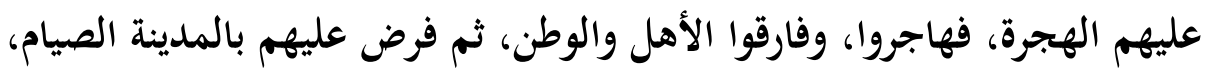

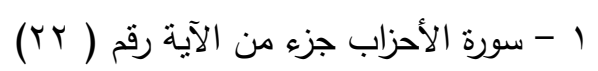
r - سورة فاطر جزء من الآية رقم ( - (1).

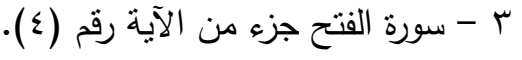

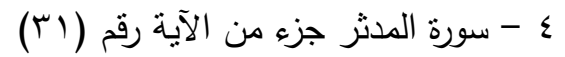

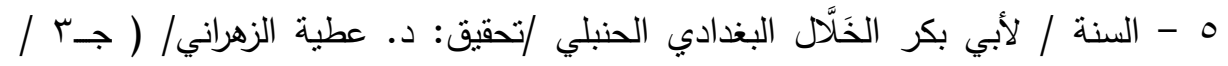

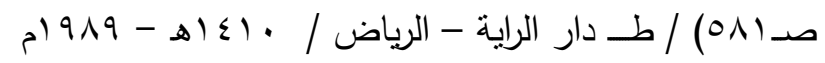

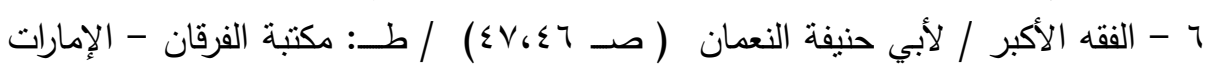

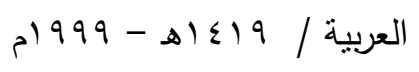


فآمنوا وصدقوا وصاموا شهر رمضان، ثم فرض عليهم الزكاة، فآمنوا وصدقوا، فروا،

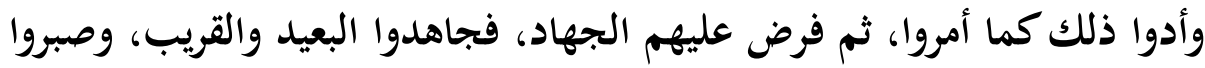

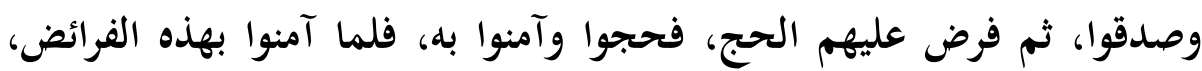

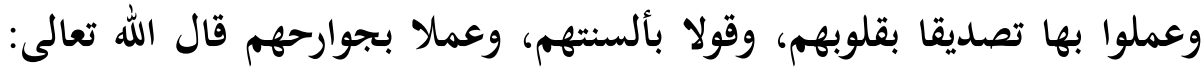

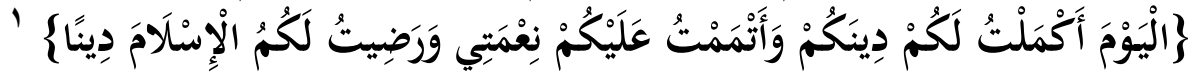

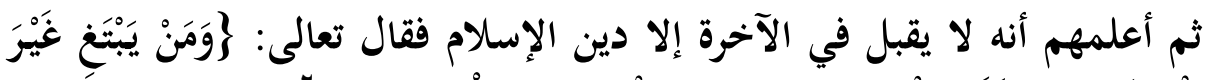

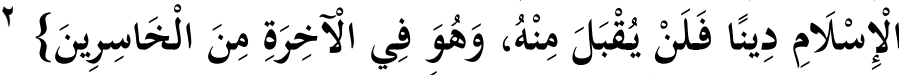

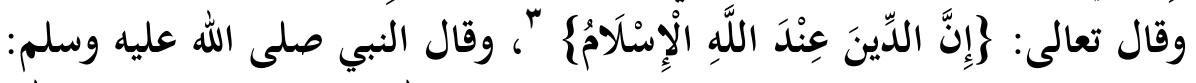

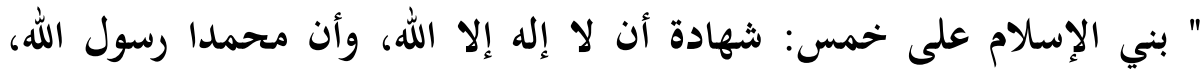

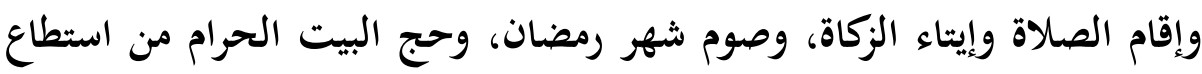

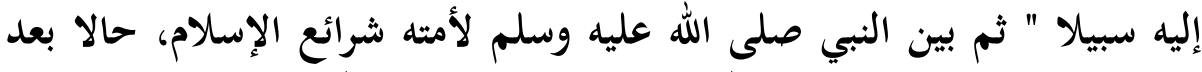

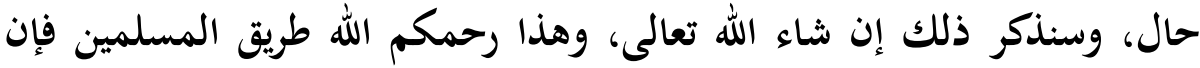

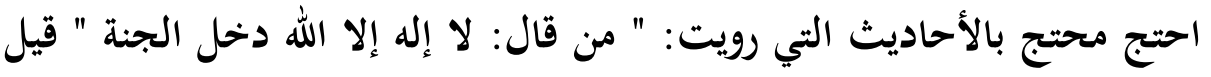

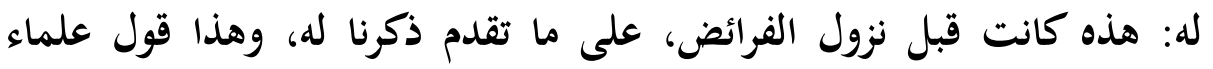

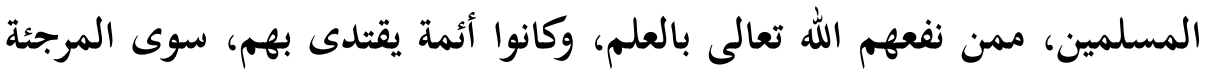

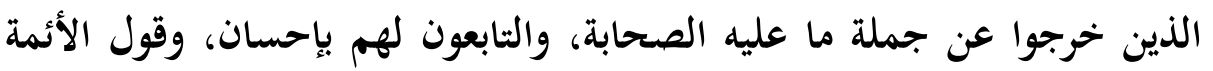

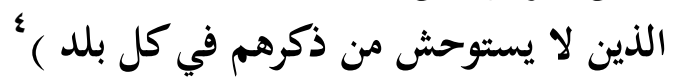

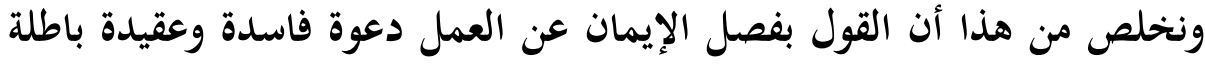

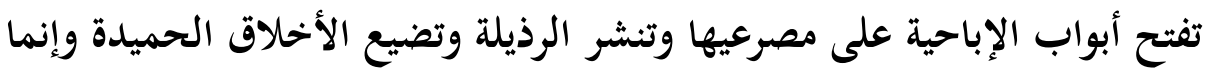

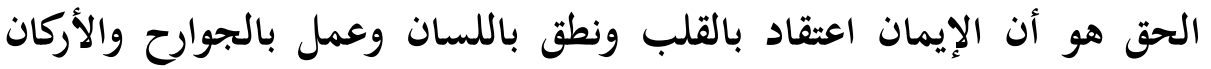

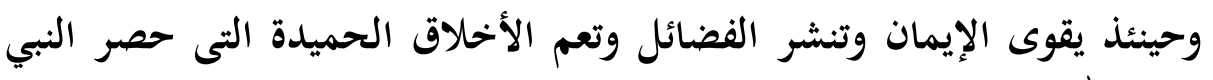
صلى الله عليه وسلم رسالثه في إتمام مكارم الأخلاق .

1 - سورة المائدة جزء من الآية رقم ( ( ).

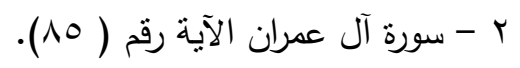

r - سورة أل عمران جزء من الآية رقم (19 (19). ع - الثريعة / لأبي بكر محمد بن الحسين بن عبد اله الآجُرِيٌٌ البغدادي / تحقيق: الدكتور

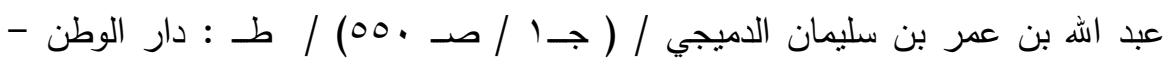

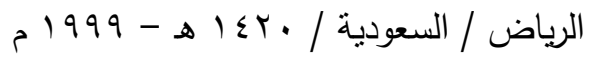


ألا إنما المرجي بالدين يمزح

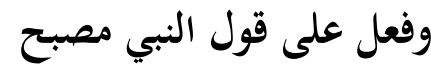

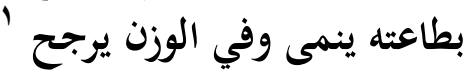

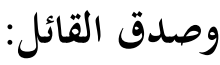

$$
\text { ولاتك مرجيا لعوبا بدينه }
$$

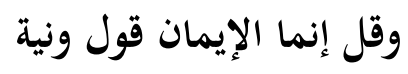

وينقص طورا بالمعاصي وتارة

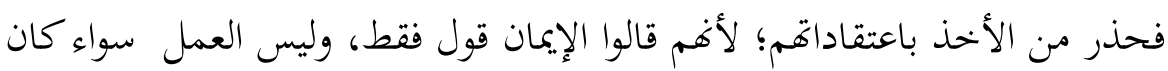

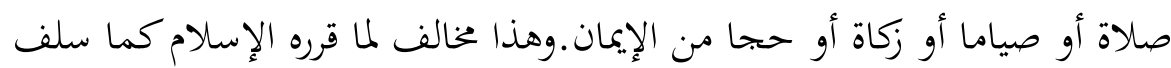

بيانه.

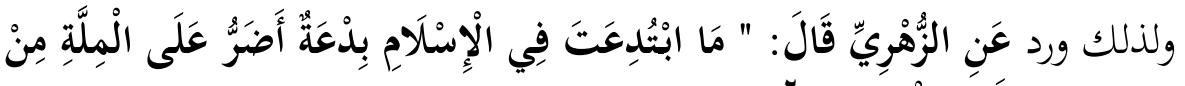

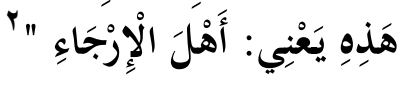

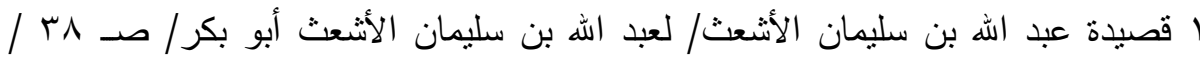

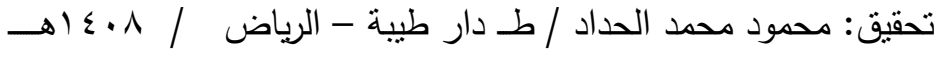

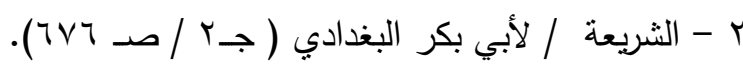




\section{المبحث الثالث}

\section{معتقدهم في مرتكب الكبيرةوملاقتها بالأخلاق ومناقشتههم}

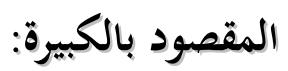

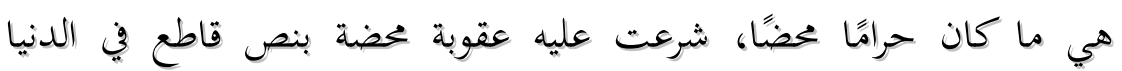

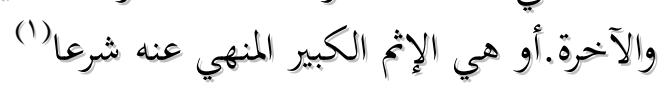

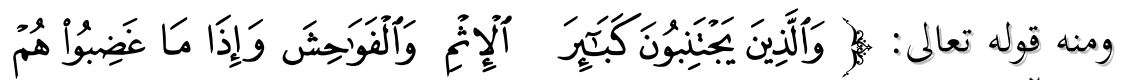

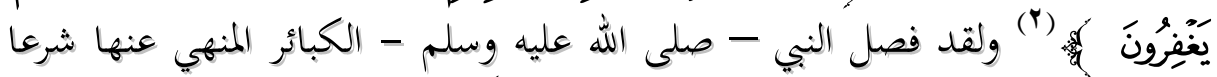

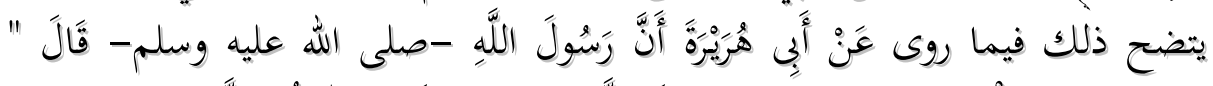

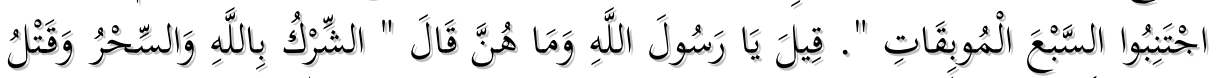

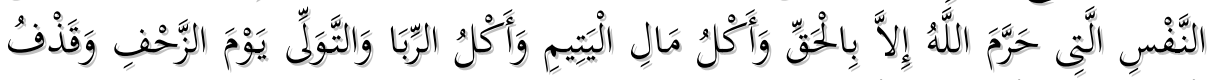

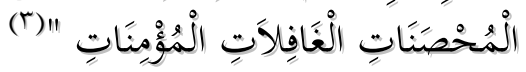

تبين لنا أن المرجئة يقولون بأنه لا تضر مع الإيمان معصية كما لا ينفع مع الكفر طاعة

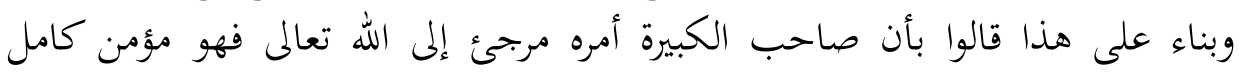
الإيمان فلا يخرج من دائرة الإيمان وهذا من (أصل مذاحهبهم ترك الكئ القطع على أهل الكبائر

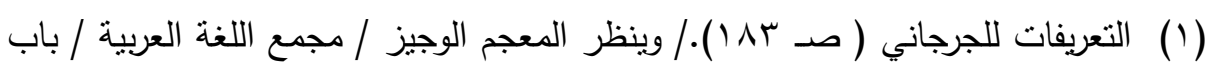

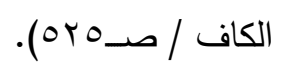

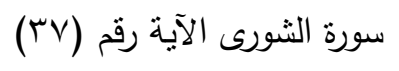

صحيح البخاري / كتاب الحدود/ باب من أظهر الفاحشة واللطخ والتهمة بغير بينة/

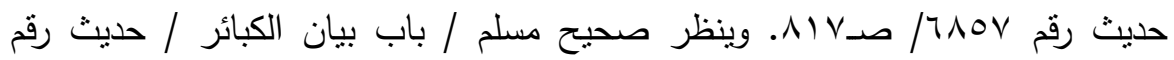

$$
\text { ( الا }
$$

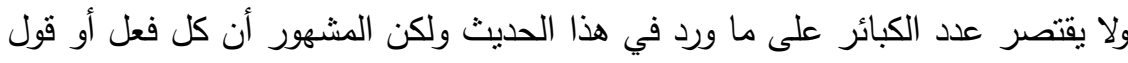

$$
\text { يترتب عليه حد أو توعد بالنار أو اللعن أو الغضب فهو الكهو كبيرة من الكبائر . }
$$


إذا ماتوا غير تائيين بعذاب أو عفو وأرجئوا أمرهم إلى الله عز وجل ولهذا سموا المرجئة)'

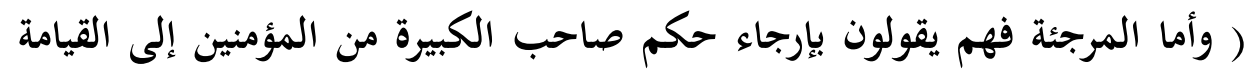

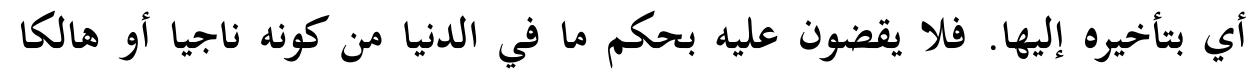

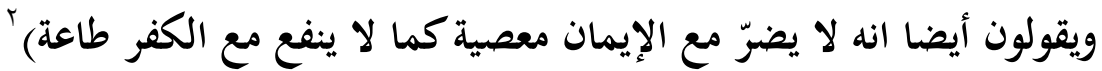

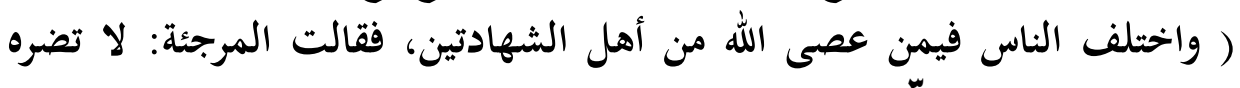

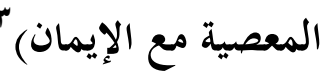
ولتهاونهم في شأن المعاصي جوزوا صدورها من الأنبياء مع اختلافهم هل هي كبائر

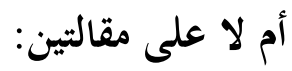
(1 - فقالت الفرقة الأولى منهم: معاصيهم كبائر وجوزوا على الأنبياء فعل الكبائر

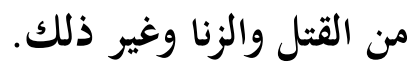

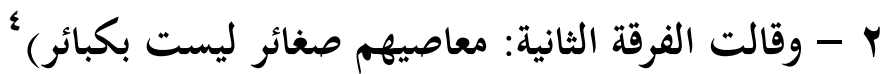

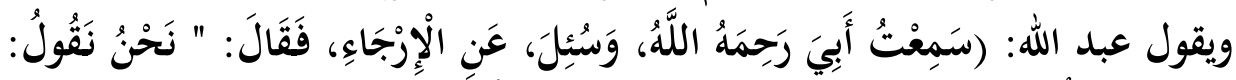

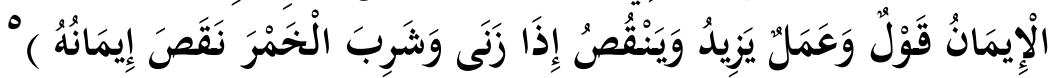

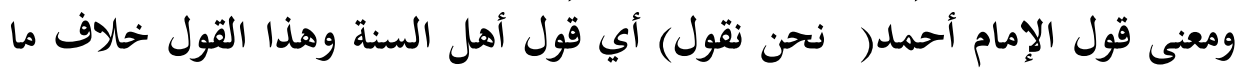

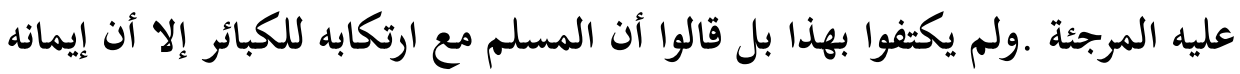

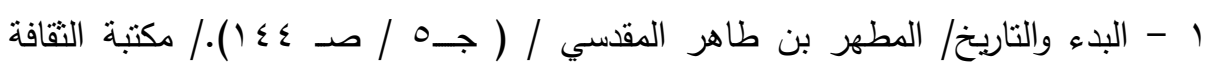
الدينية، بور سعيد بدون r - تاريخ مختصر الدول/ لأبي الفرج المعروف بابن العبري / تحقيق: أنطون صالحاني

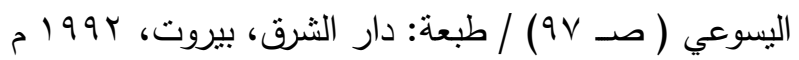

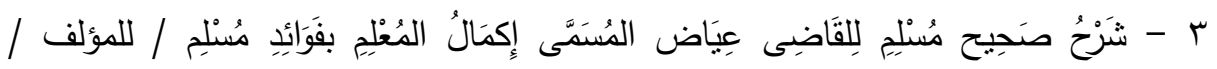

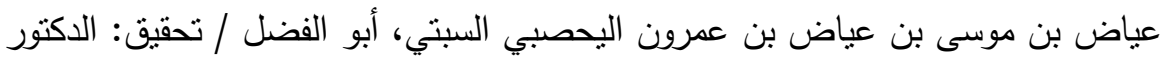

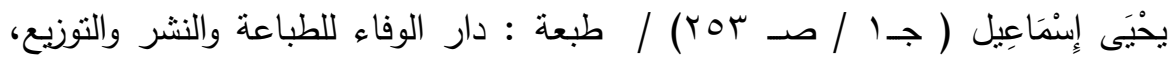

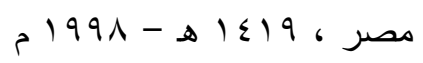
ع - مقالات الإسلاميين واختلاف المصليين للأثتعري ( صـ بـ أ).

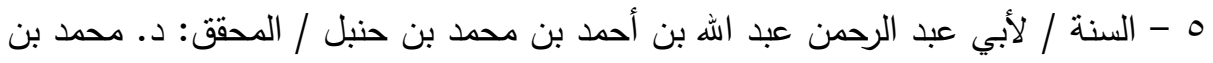

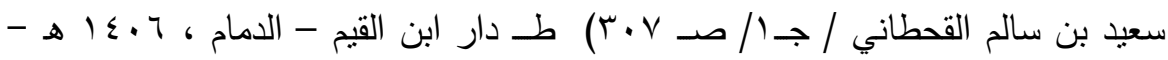


كإيمان الملائكة والرسل (قول المرجئة الفْاسِقِ مَعَ فسقه مُؤمن مُسلم إيمَانه

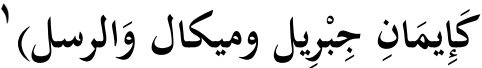

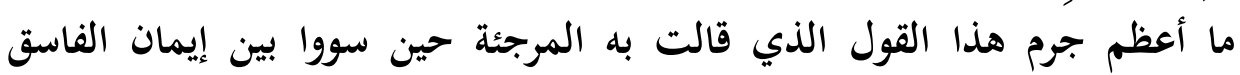

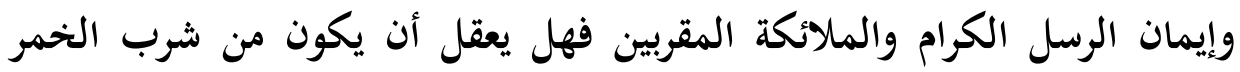

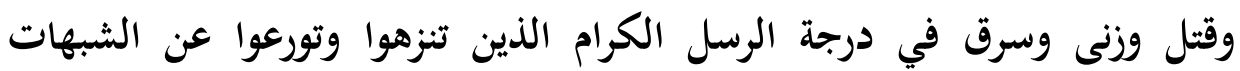

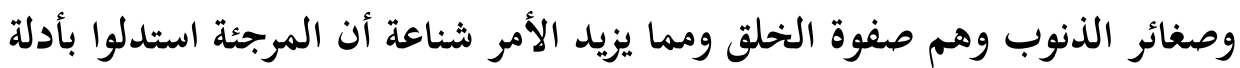

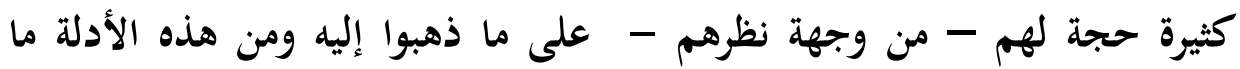
يلي:-

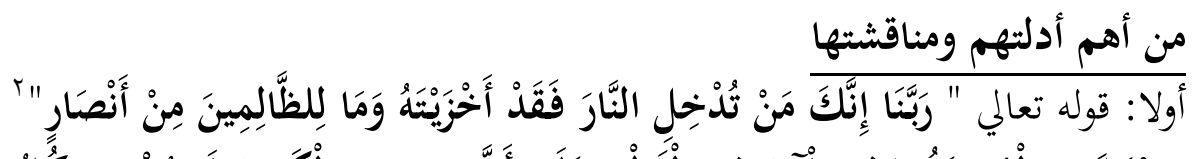

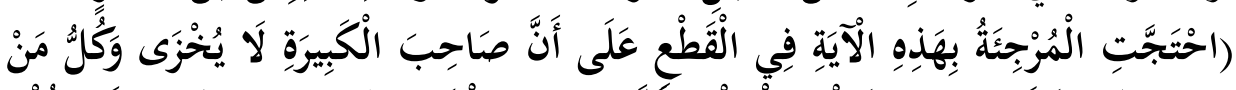

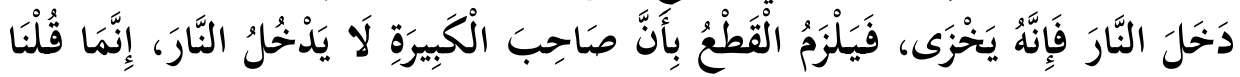

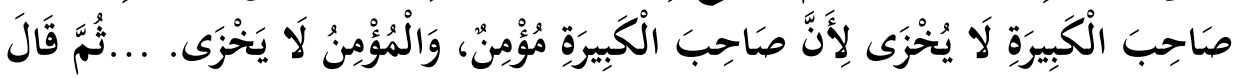

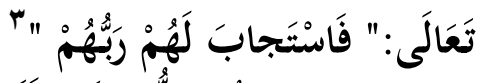

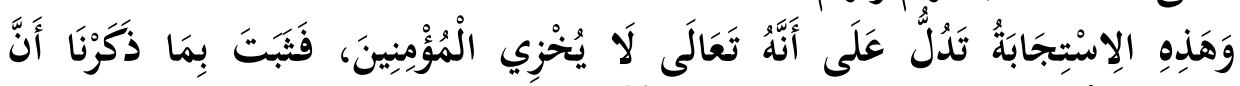

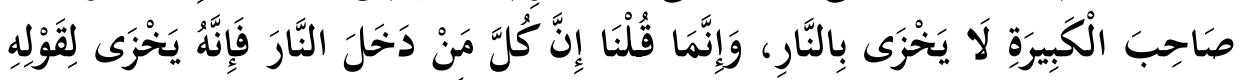

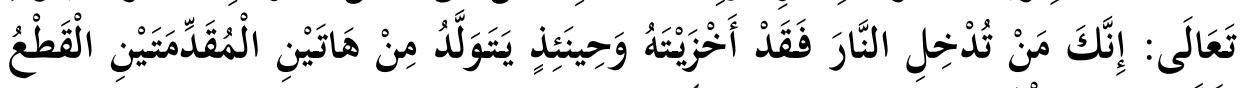

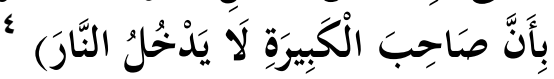

1 - التتبيه والرد على أهل الأهواء والبدع لهحد بن أحمد بن عبد الرحمن، أبو الحسين

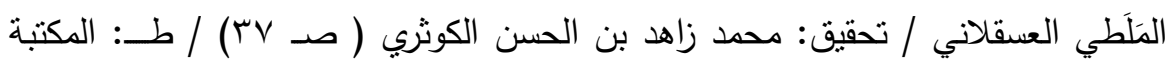
الأزهرية للتراث - مصر بدون.

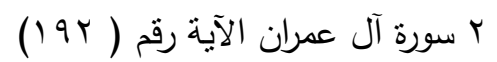

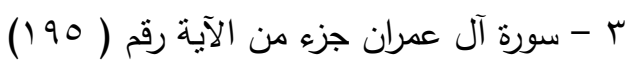

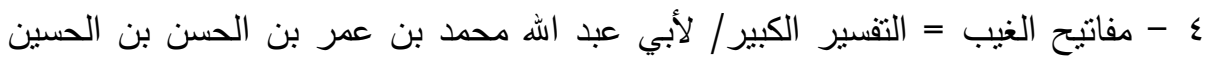

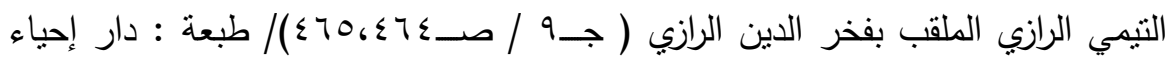

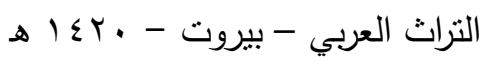




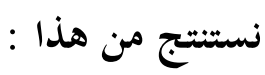

يستدل المرجئة على أن صاحب : الكبيرة لا يدخل النار احتجاجا بأن الله تعالى يستجيب

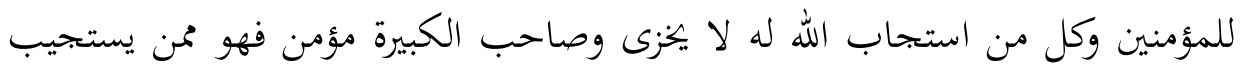

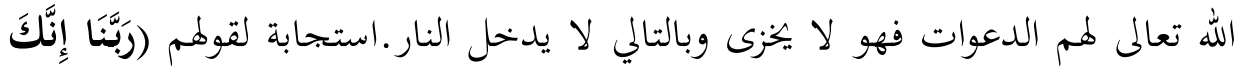

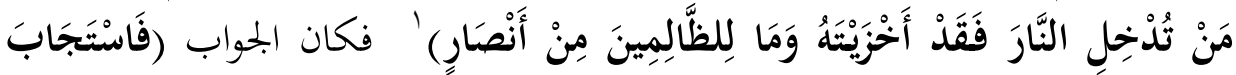

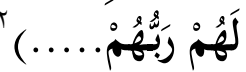
فبناء على هذا يكون صاحب الكبيرة مؤمن فلا يدخل النار.

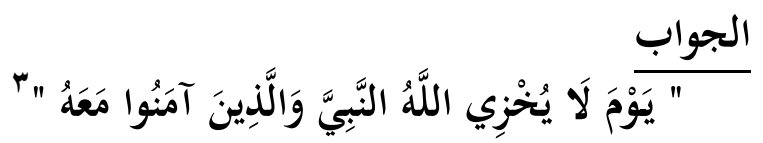

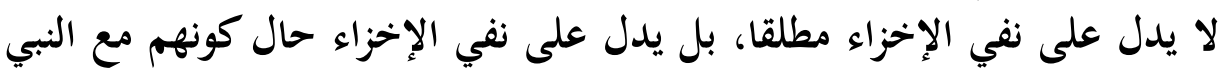

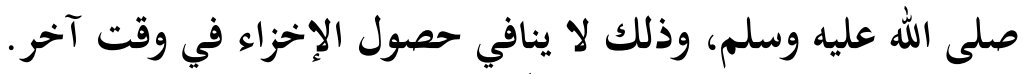

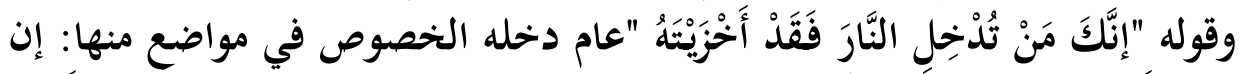

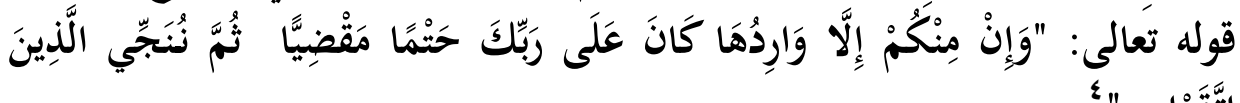

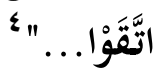
يدل على أن كل المؤمنين يدخلون النار، وأهل الثواب يصانون عن الخزي.

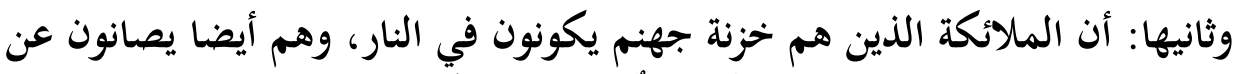

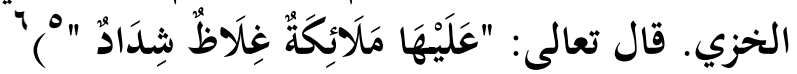

$$
\begin{aligned}
& \text { ا سورة آل عمران الآية رقم ( كو (1) } \\
& \text { r - سورة آل عمران جزء من الآية رقم (190 (190) } \\
& \text { r - سورة التحريم جزء من الآية رقم ( (^). }
\end{aligned}
$$

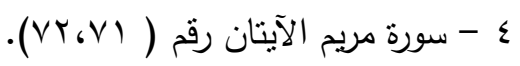

$$
\begin{aligned}
& \text { ه - جزء من الآية رقم (7) (7). }
\end{aligned}
$$

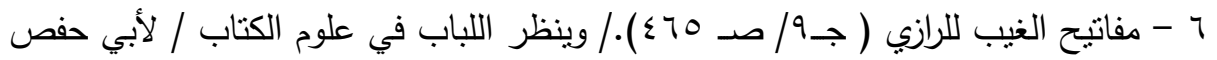

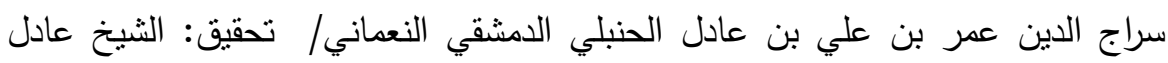

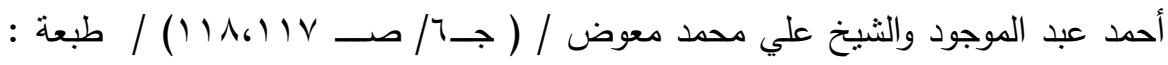

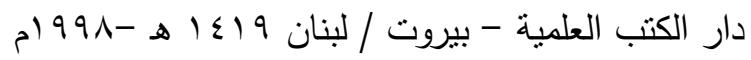


أن الإمام الرازي قد مد هذا هذا التأويل الخاطئ الذي قالت به المرجئة - الذي عرض سابقا-

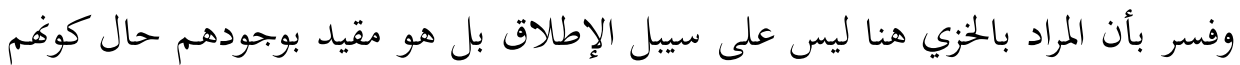

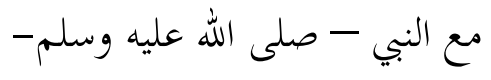
تم بين أنه ليس كل من دخل النار يصاب بالحزي، فالآية عامة، ولكن هناك خصوص،

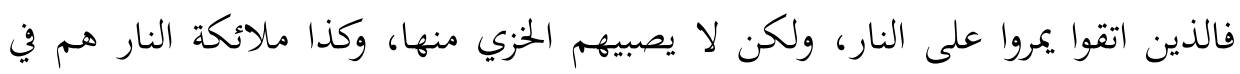

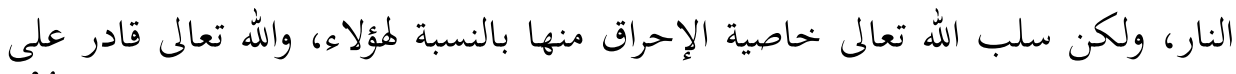

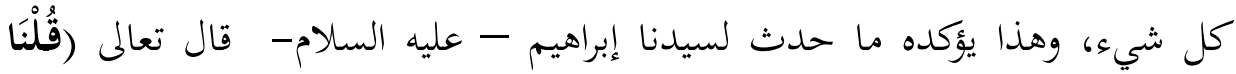

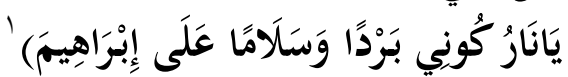

وكما خص الله تعالى منع نزول العذاب على الكفار لوجود سيدنا محمد بين ظهرانيهم

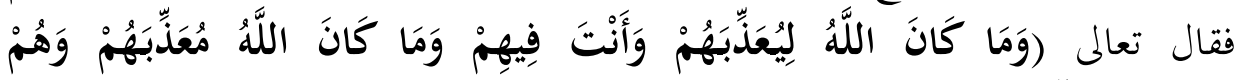

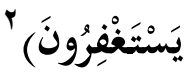

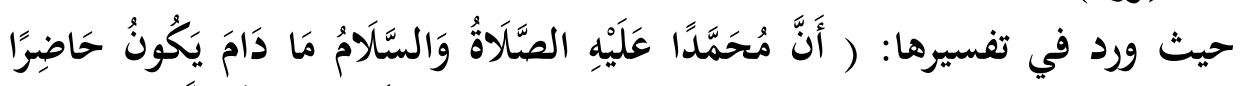

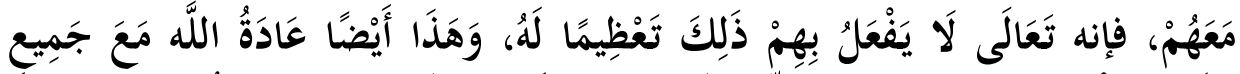

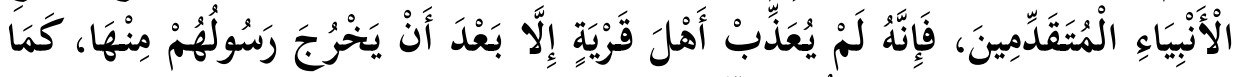

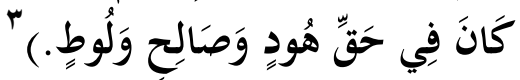

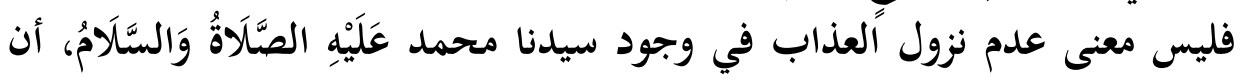

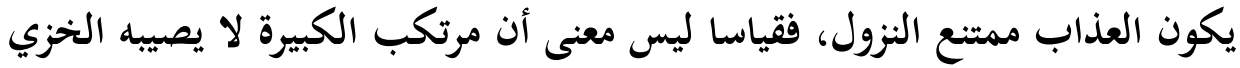

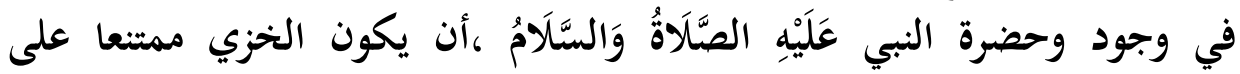

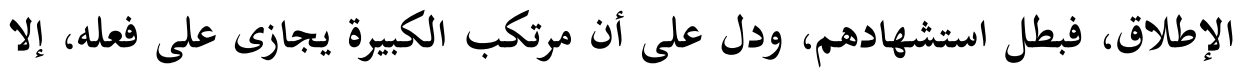

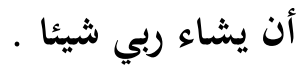

$$
\begin{aligned}
& 1 \text { - سورة الأنبياء الآية رقم (79) } \\
& \text { r - سورة الأففال الآية رقم ( س الاية رقم). }
\end{aligned}
$$

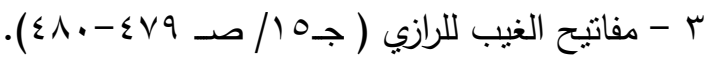




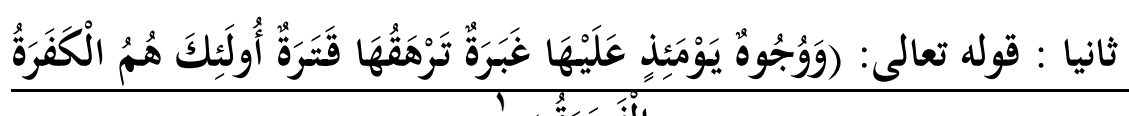

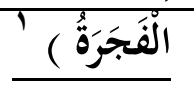

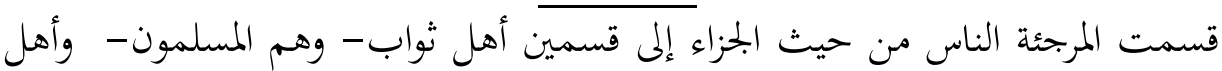

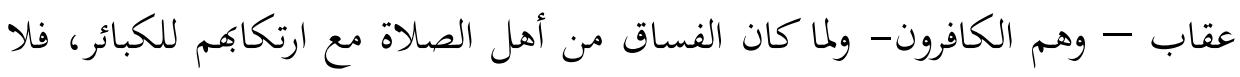

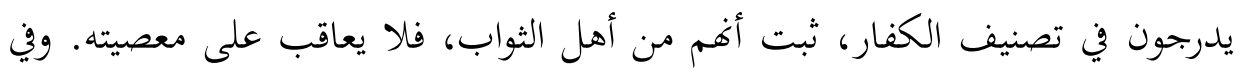
هذا يقول الرازي:

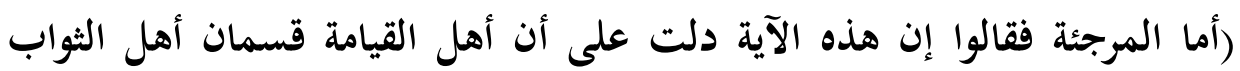

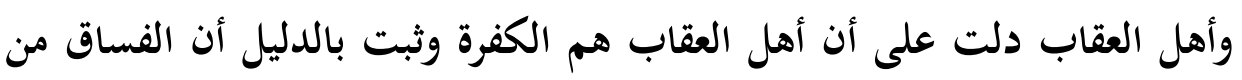

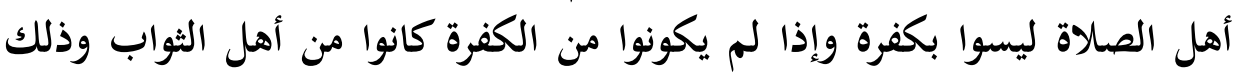

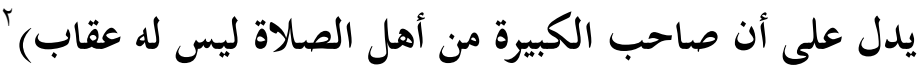

(أكثر ما في الباب أن المذكور هاهنا هو هذا الفريقان، وذلك لا يقتضي نفي

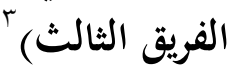

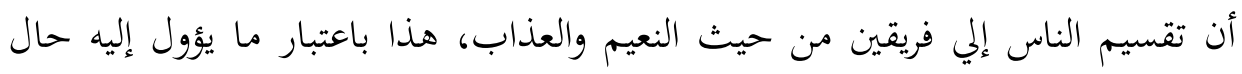

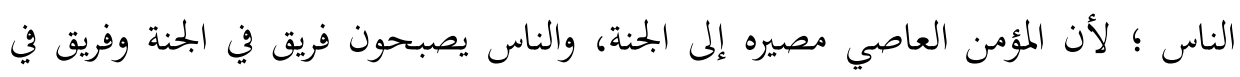

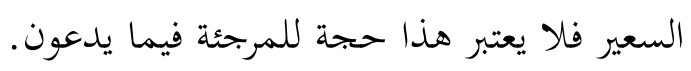

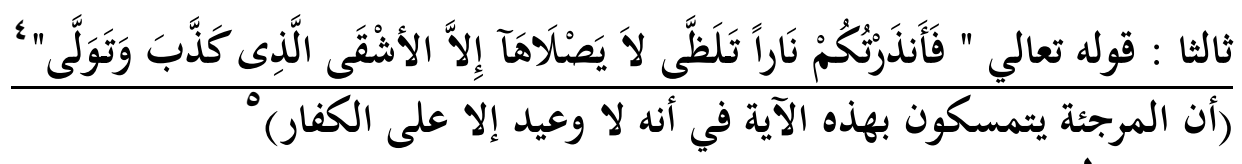

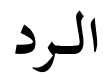

(فإنكم لا تقطعون بعدم وعيد الفساق الجواب من وجهين الأول ما ذكره الواحدي

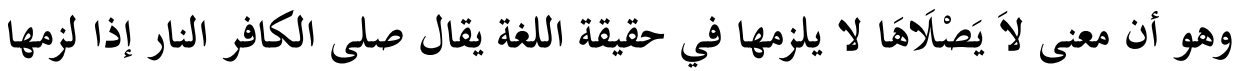

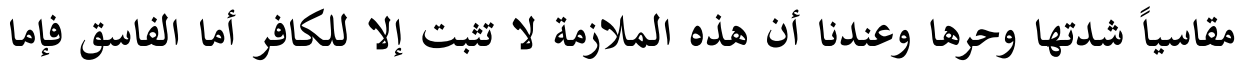

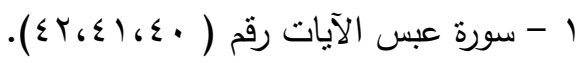

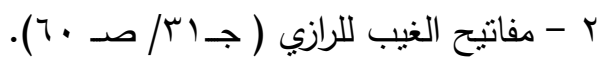

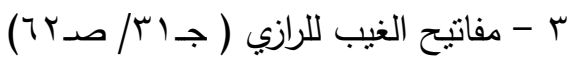

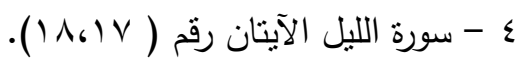

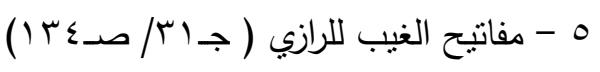


أن لا يدخلها أو إن دخلها تخلص منها الثاني أن يخص عموم هذا الظاهر بالآيات

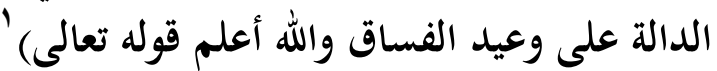

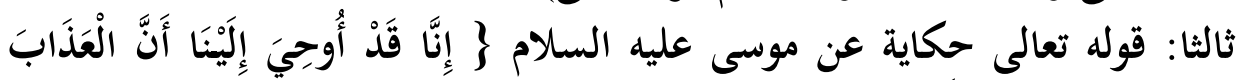

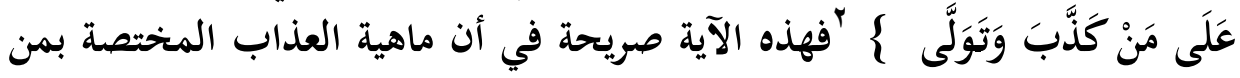

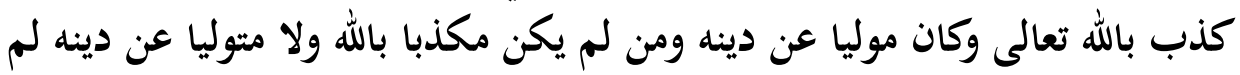

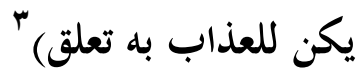
الرد إحن

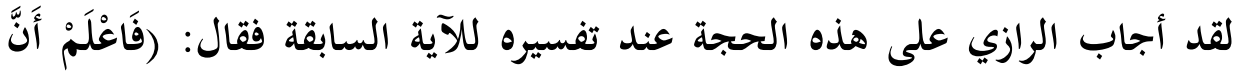

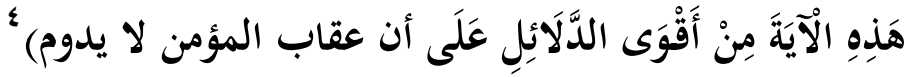

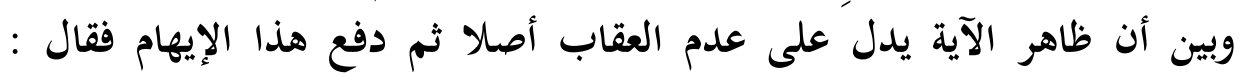

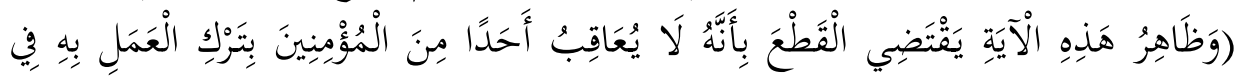

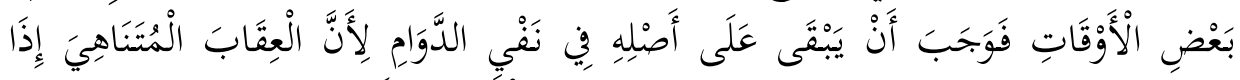

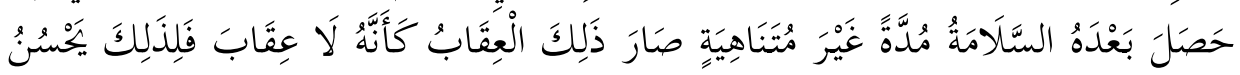

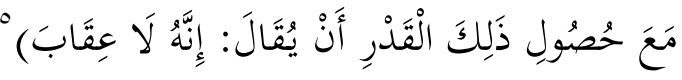

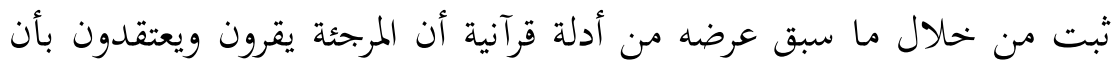

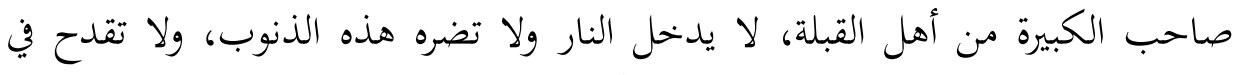

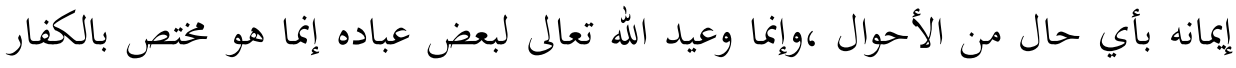

ثانيا : استدلالهم بالسنة النبوية:

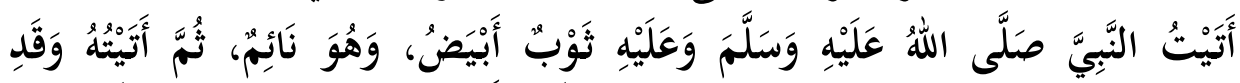

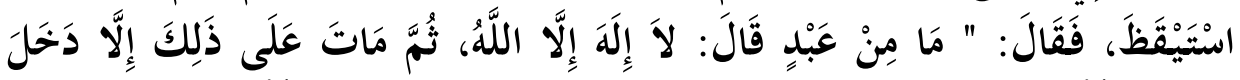

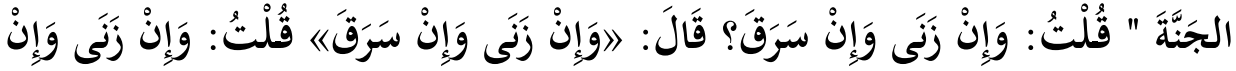

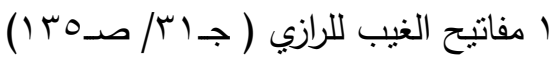

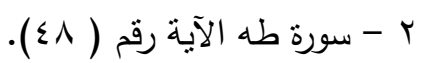

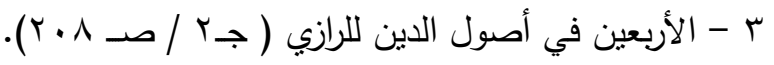

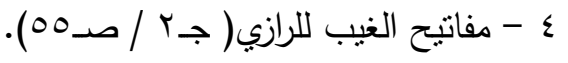

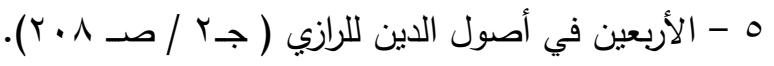




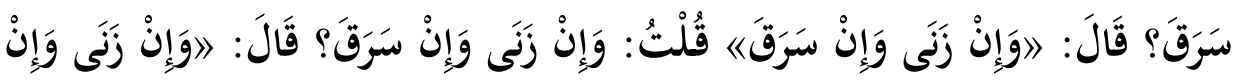

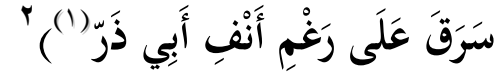

\section{الرداد الرد}

تلك الأحاديث العامة المطلقة تقيد بالأحاديث الأخرى، فقد جاء عن الصديق الهاء

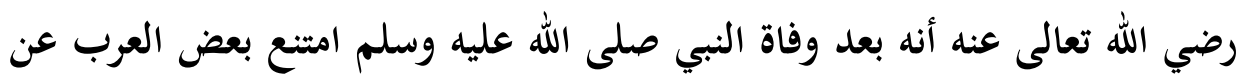

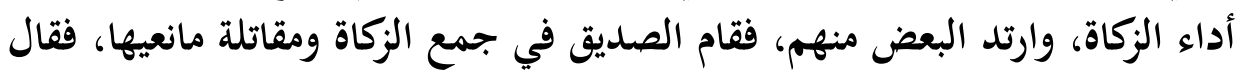

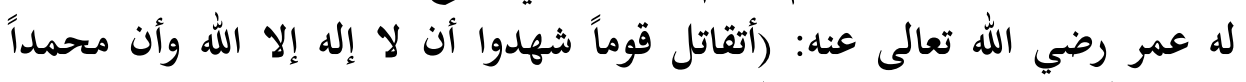

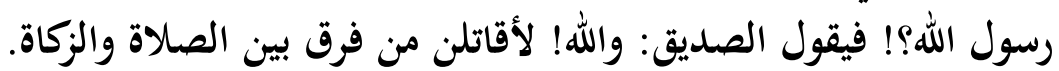

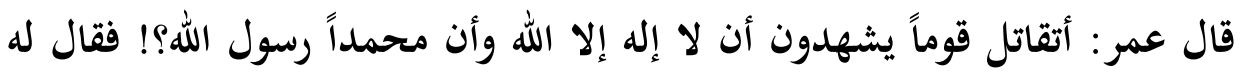

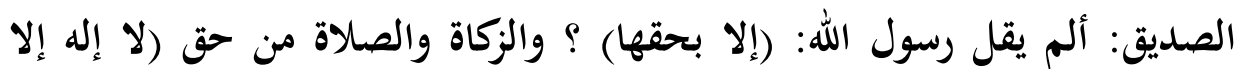

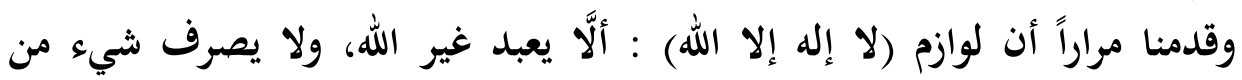
العبادة لغير الله؛ لأنه اعترف بأنه لا مألوه بحق ولا لالا يستحق الألوهية والعبادة إلا ئل الله. ومقتضى (محمد رسول الله) : أن يطيع الله بما أرسل به رسوله.

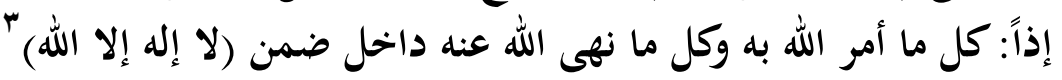

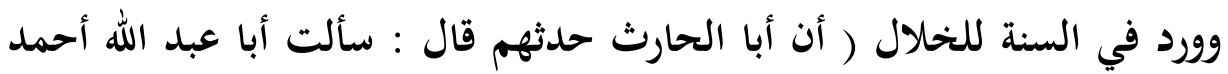
بن محمد بن حنبل ، قلت : إذا قال الرجل : لا إله إلا الله ، فهو مؤمن ؟ قال : الهال :

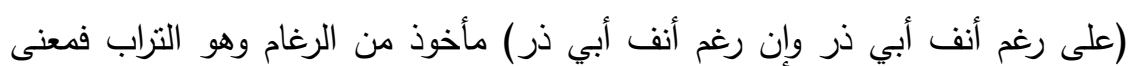

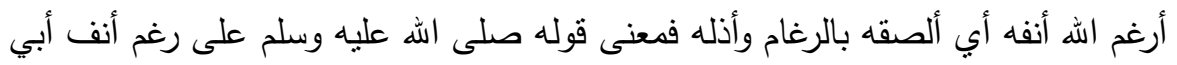

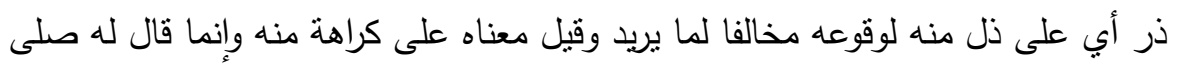

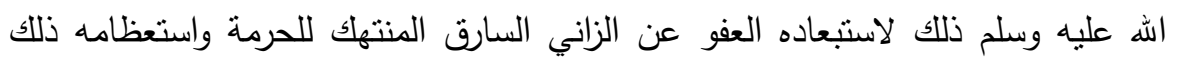

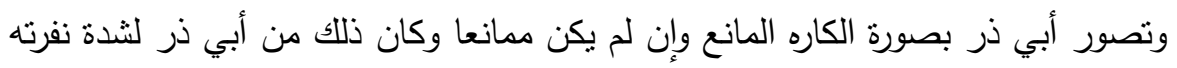

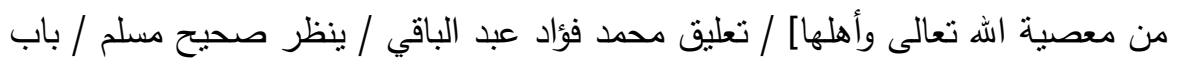

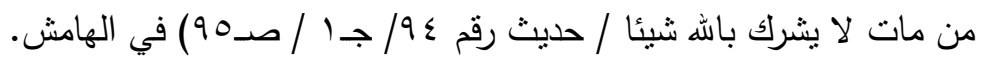

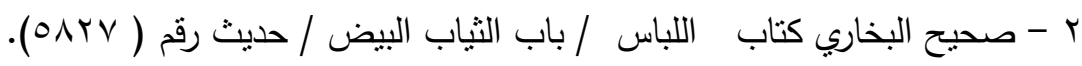

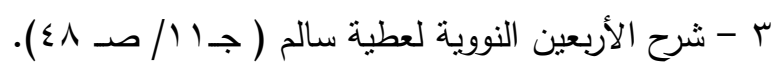


كذا كان بدء الإيمان ، ثم نزلت الفرائض : الصلاة ، والزكاة ، وصوم رمضان ،

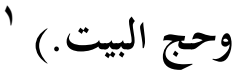

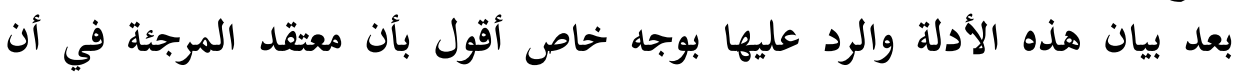

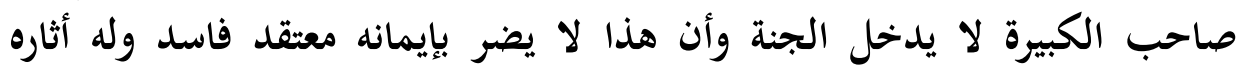

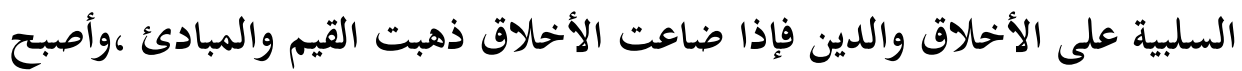

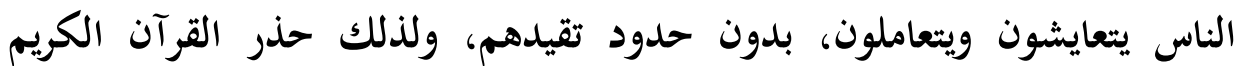

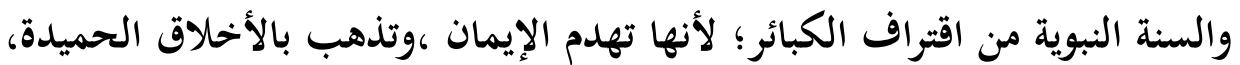

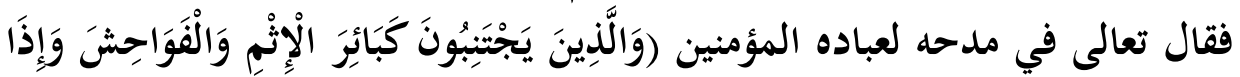

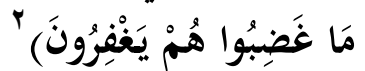

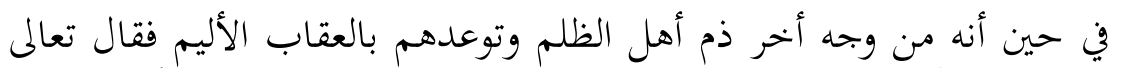

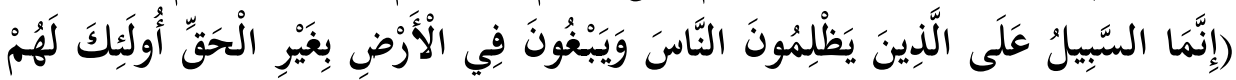

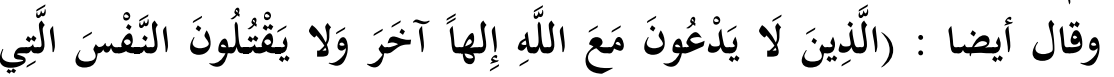

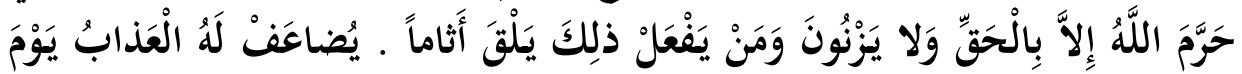

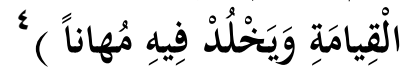

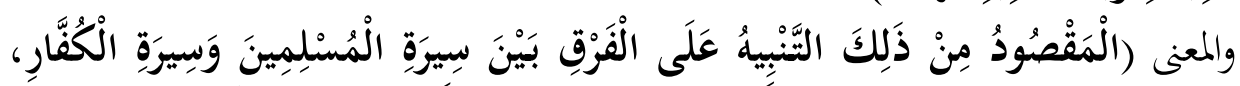

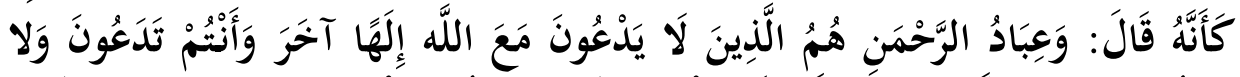

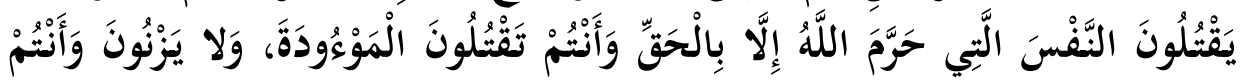

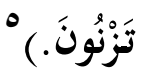

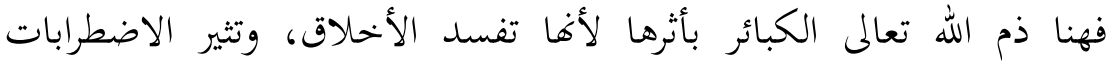

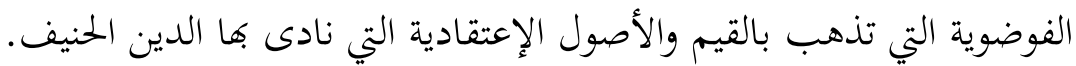

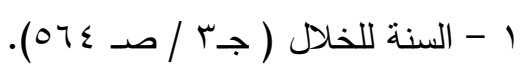

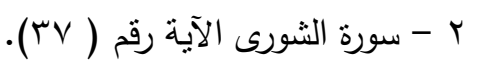

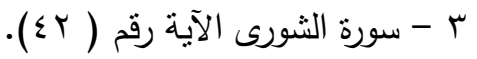

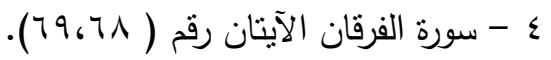

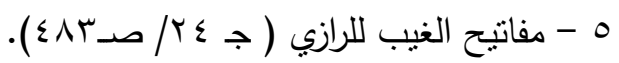


فمثلا على هذا أن قابيل قد ندم على قتل هابيل كما وضح لنا القرآن الكريم

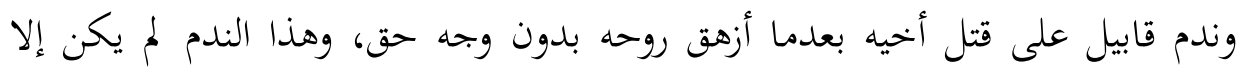

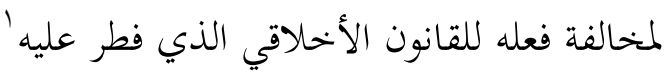

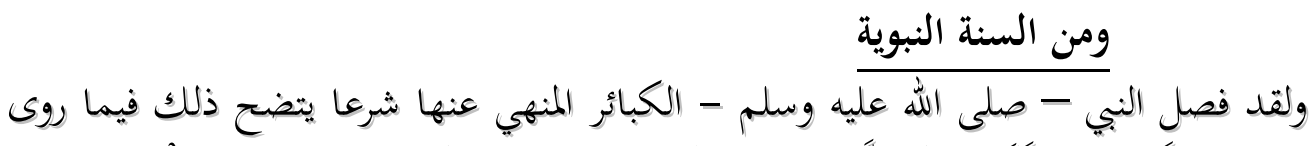

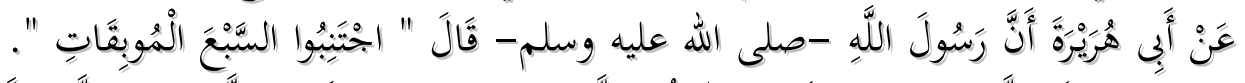

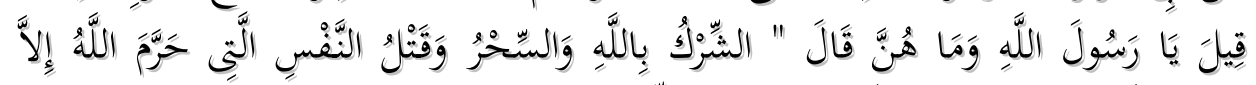

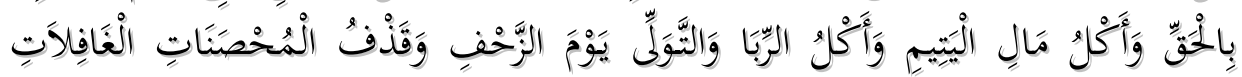

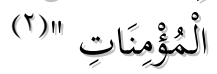

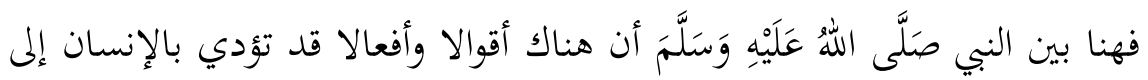

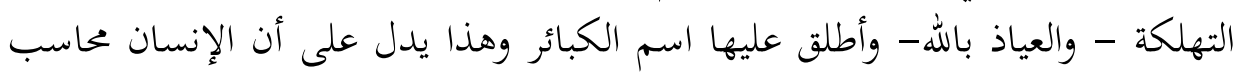

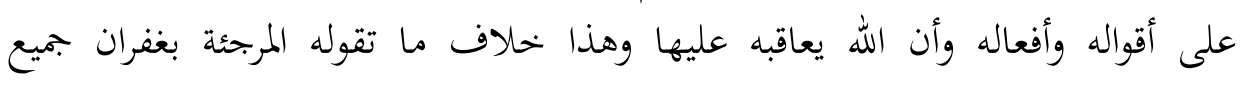

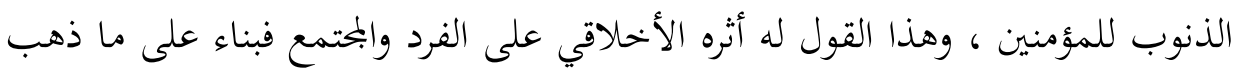

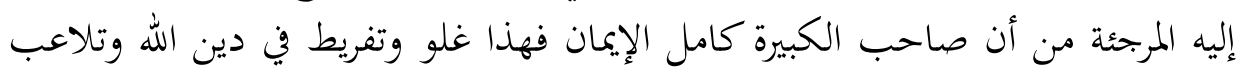

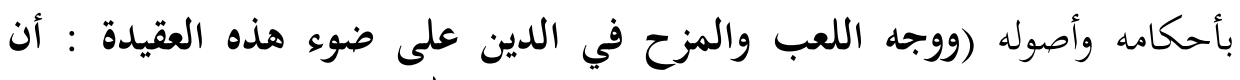

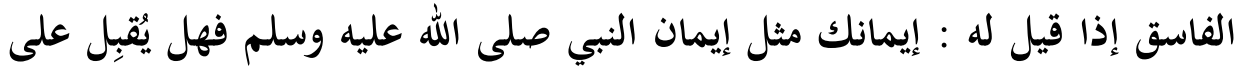

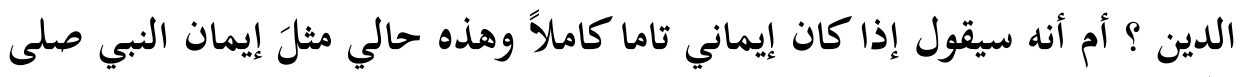

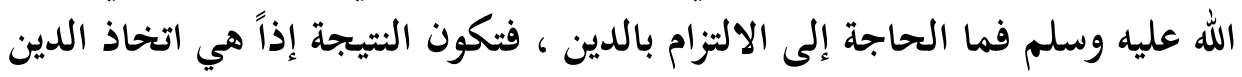

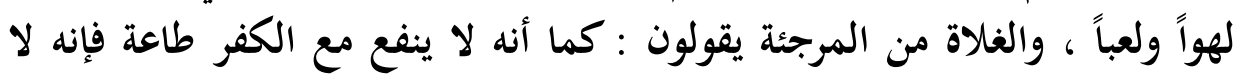

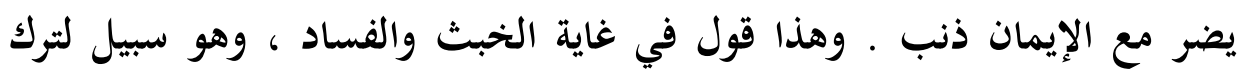

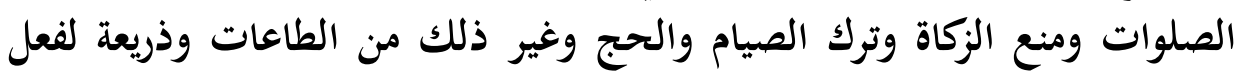

$$
\text { 1 - مشكلة الخير والثر في الفكر الإسلامي ( صـ 9 ؟) بتصرف. }
$$

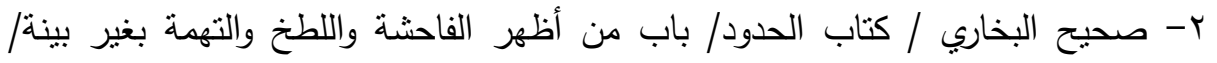

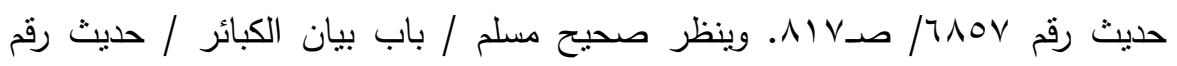

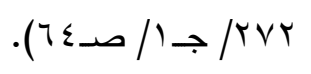

ولا يقتصر عدد الكبائر على ما ورد في هذا الحديث ولكن الشهور أن كل فعل أو قول

$$
\text { يترتب عليه حد أو توعد بالنار أو اللعن أو الغضب فهو لكو كبيرة من الكبائر . }
$$


الفواحش والموبقات ولا يرتاب عاقل أنه هذا لعب بالدين ، وأي عبث أفضع وأشد

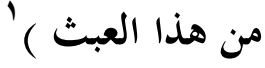

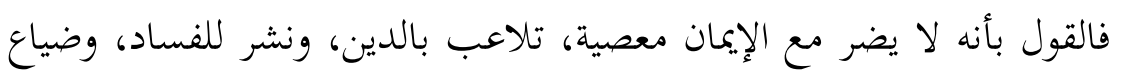

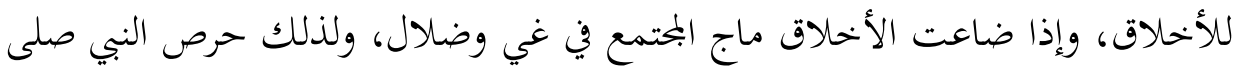

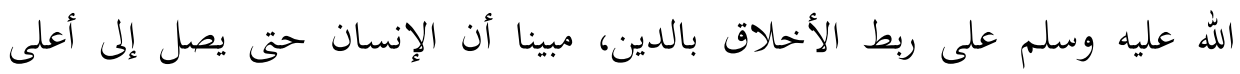

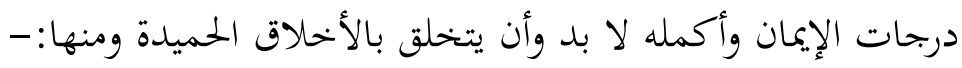

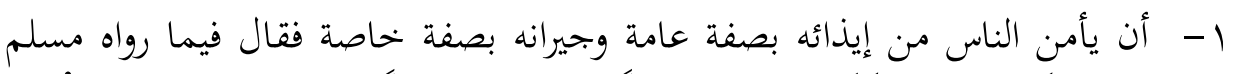

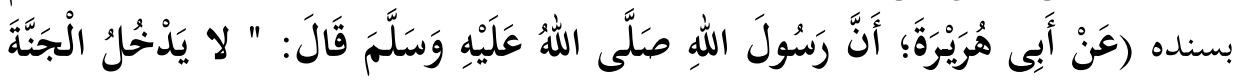

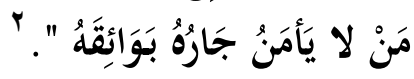

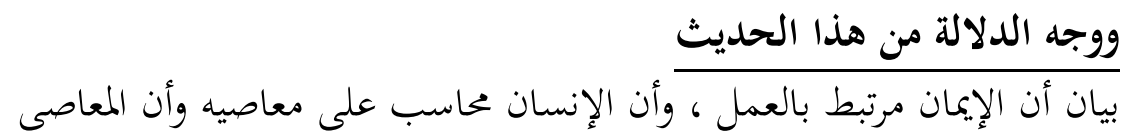

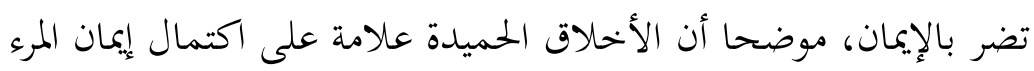

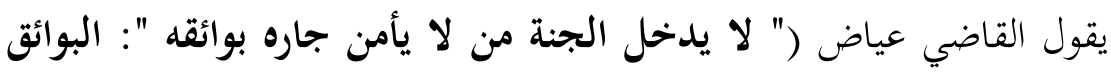

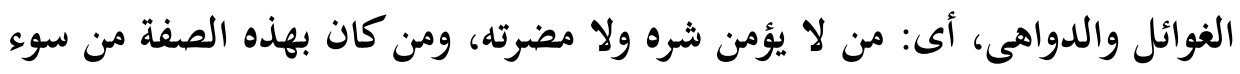

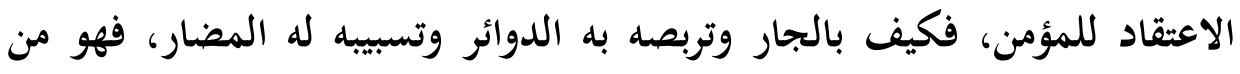

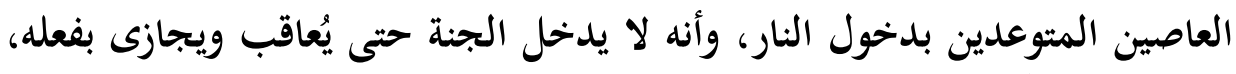

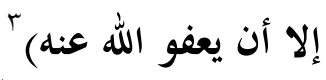

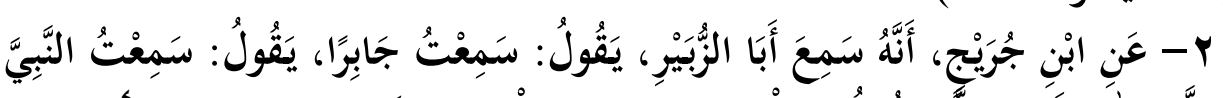

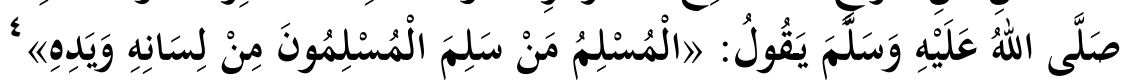

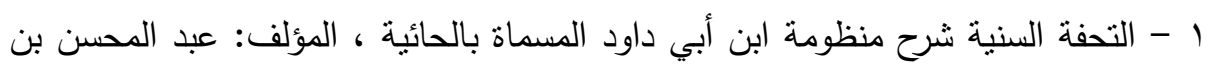

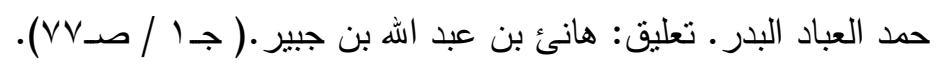

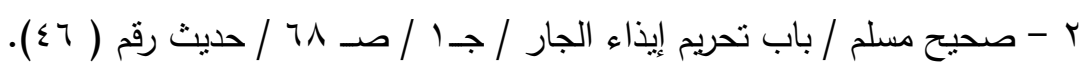

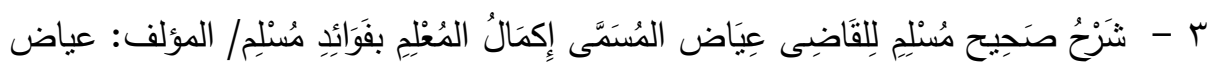

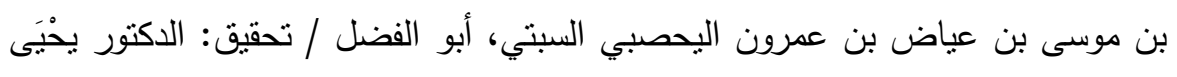

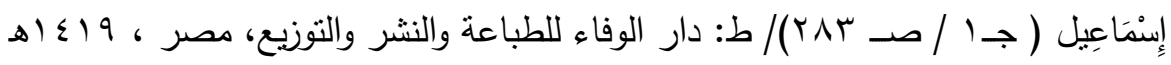
م1991ع - صحيح مسلم / باب بيان تفاضل الإسلام / جـ / / صد 10 / حديث رقم ( ( ). 
وفي هذا الحديث يحذر النبي صلى الله عليه وسلم من إيذاء المسلم لأخيه سواء

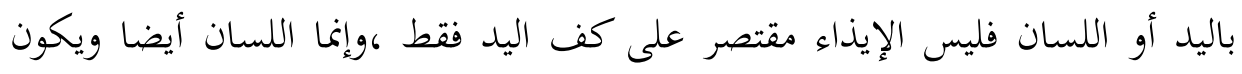

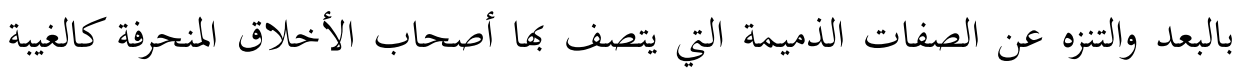

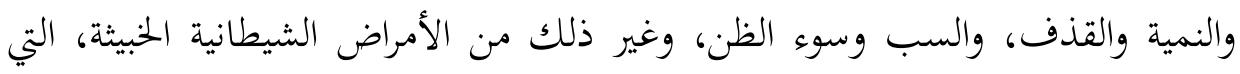

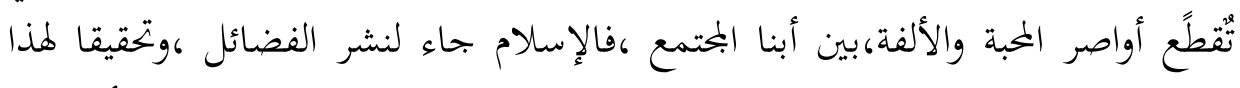

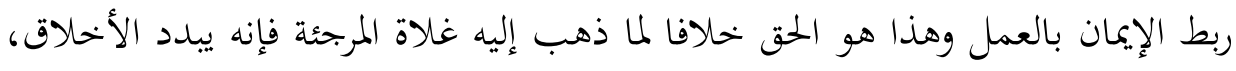

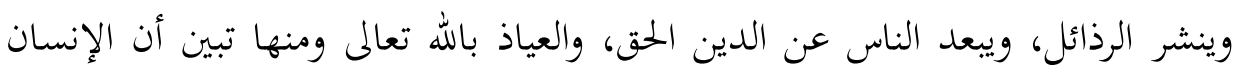

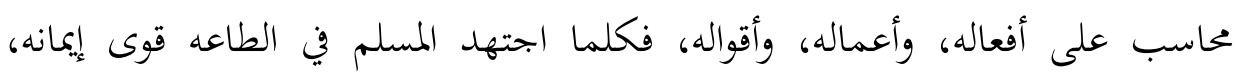
والعكس كلما تلاعب بالدين وعصى ربه قل إيمانه،وحسابه على تقصيره وعصيانه. 


\section{المبتحث الثرابع \\ موقفهرم من الشفامة وملاقتهها بالأخلاق}

بناء على ما سبق ذكره من معتقد المرجئة في جزاء مرتكب الكبيرة وتقريرهم

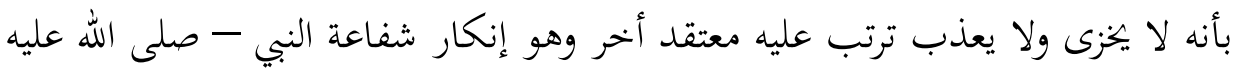

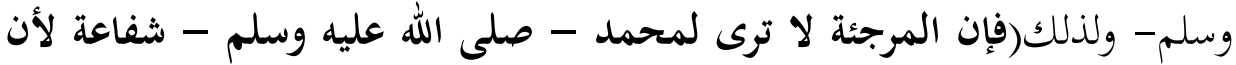
لا لا إله إلّا الله تغني عنها)

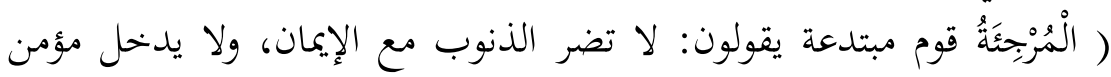

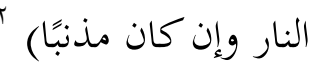

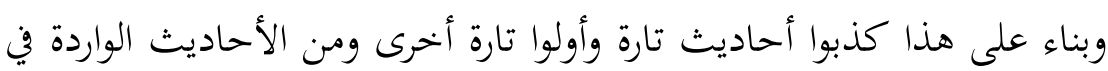

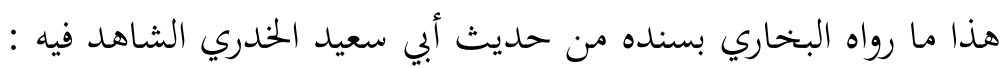

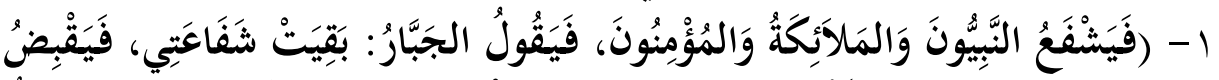

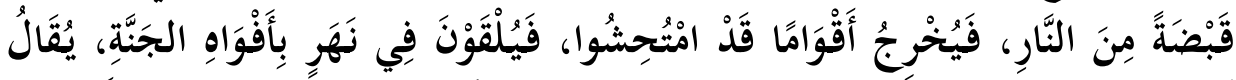

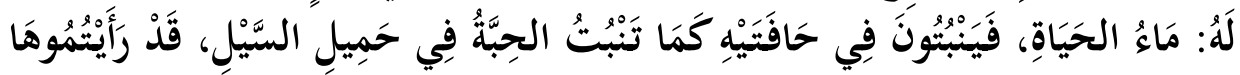

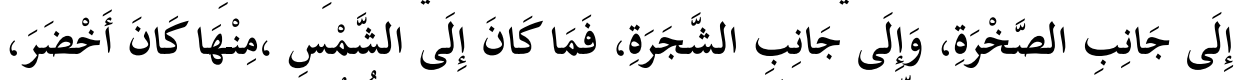

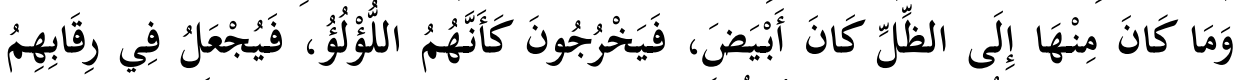

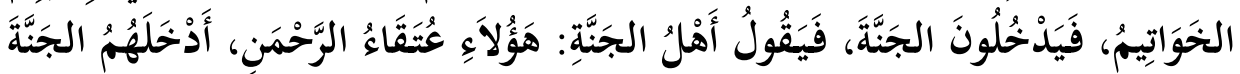

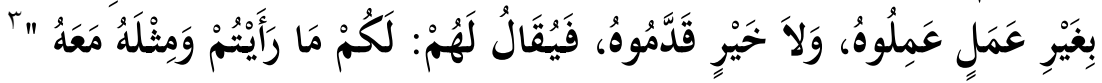

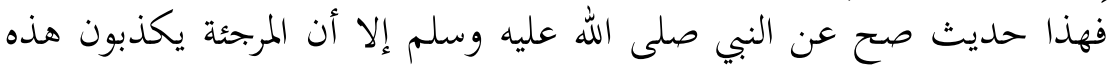

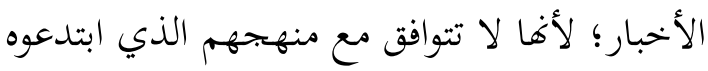

1 - قبس في شرح موطأ مالك بن أنس/ للقاضي محمد بن عبد الله أبو بكر بن العربي

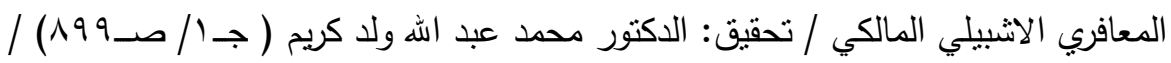

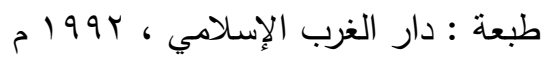

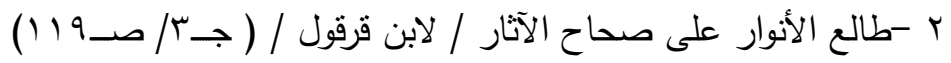

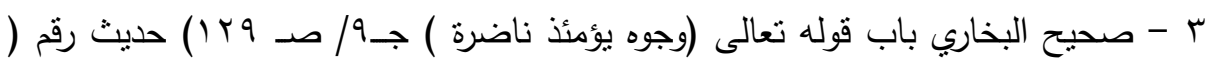




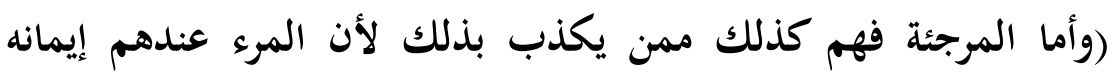

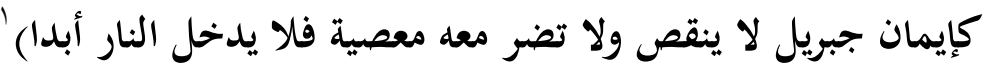

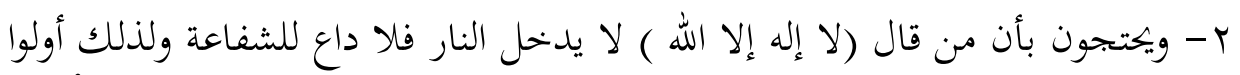

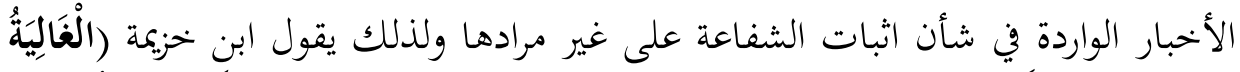

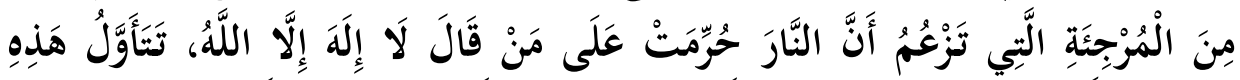

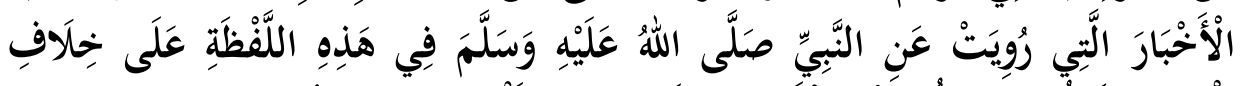

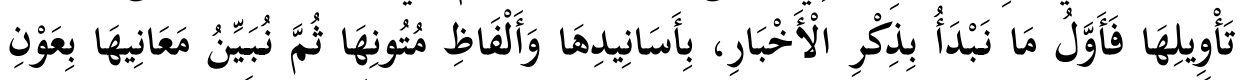

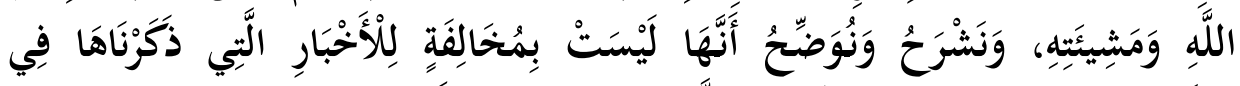

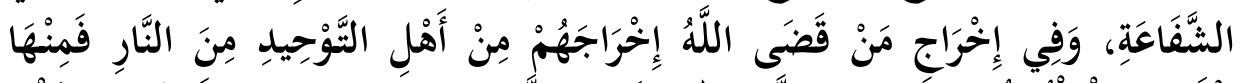

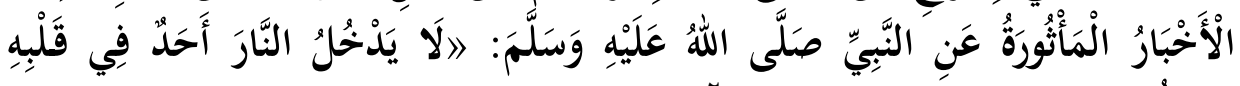

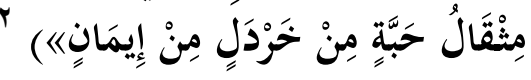

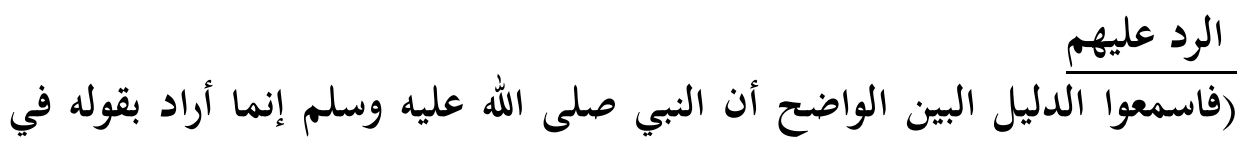

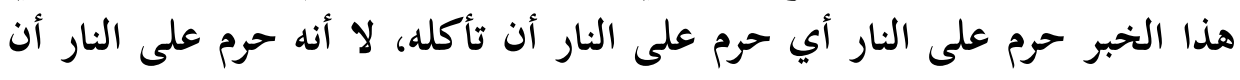

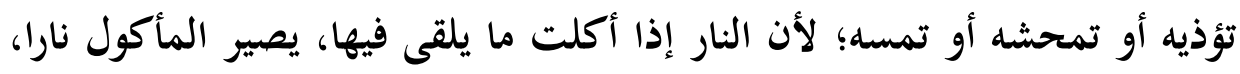

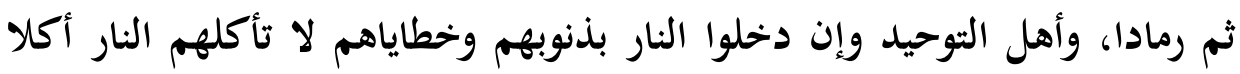

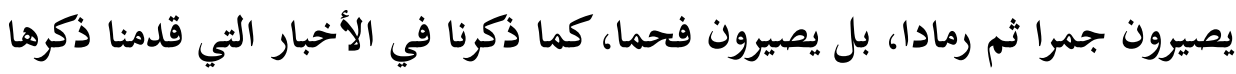

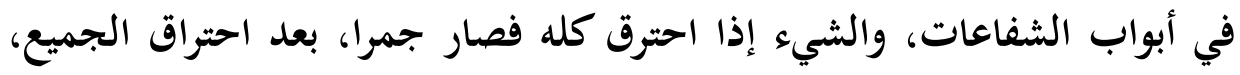

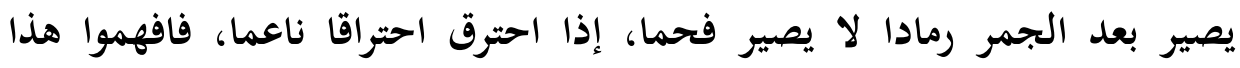

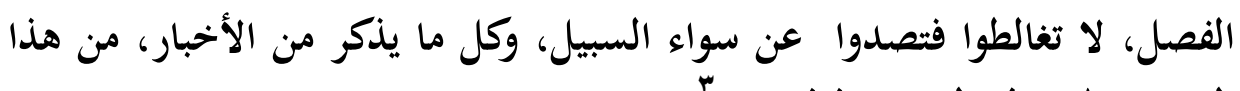

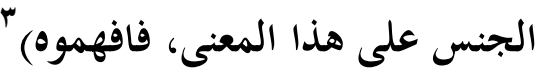

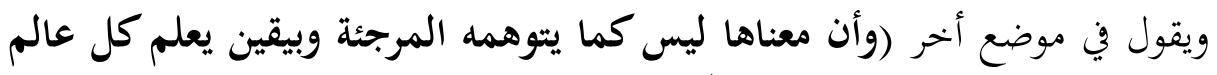

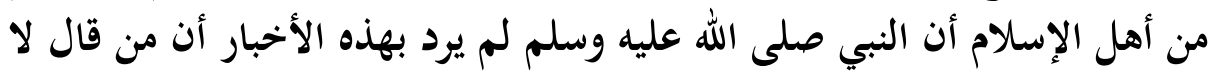

$$
1 \text { - مصيدة عبد الله بن سليمان الأثشعث ( صـ000). }
$$

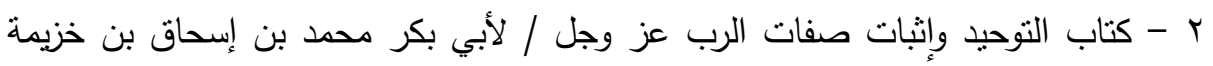

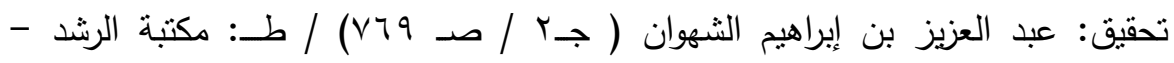

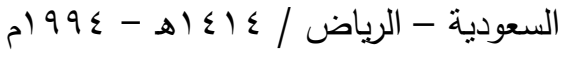

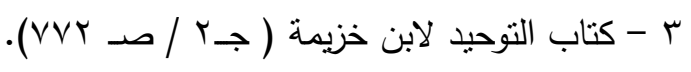




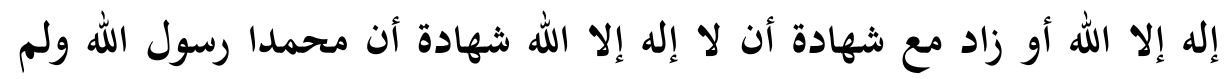

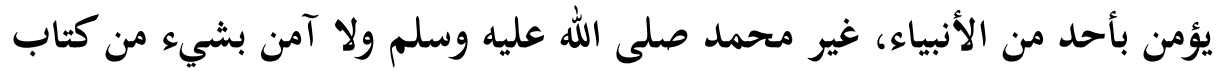

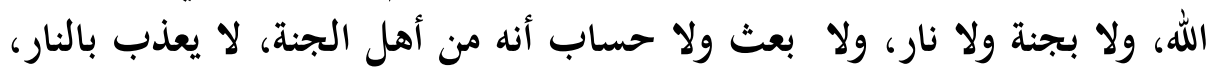

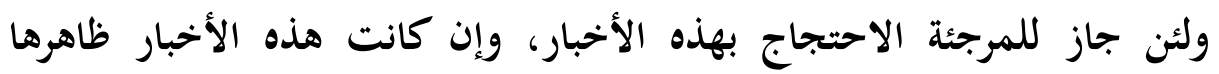

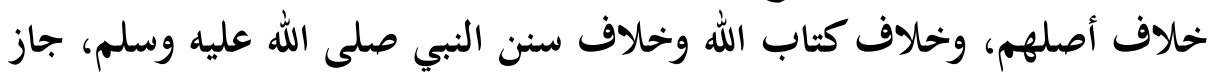

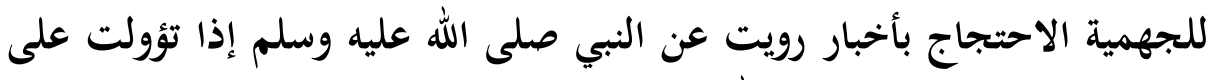

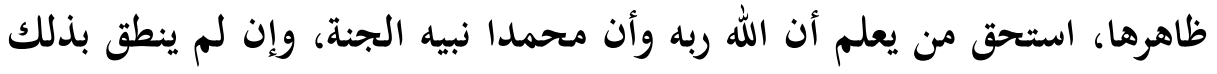

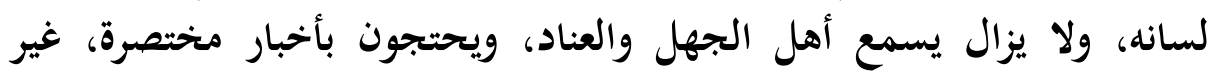

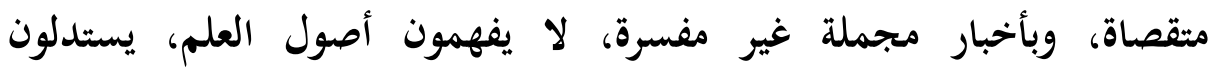

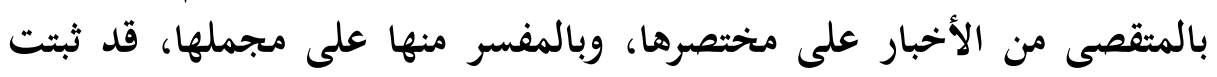

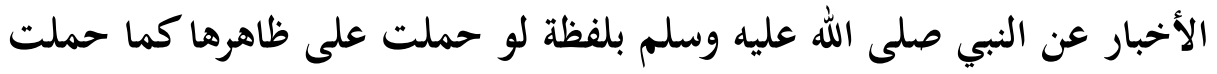

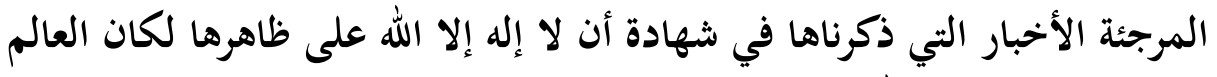

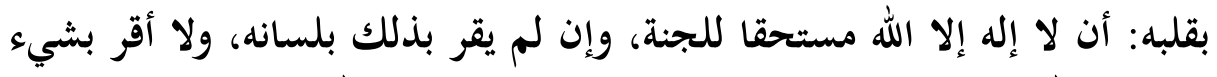

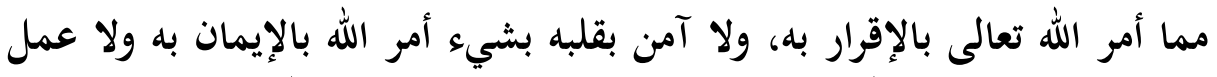

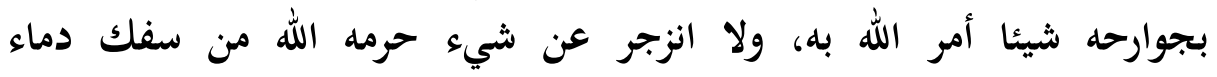

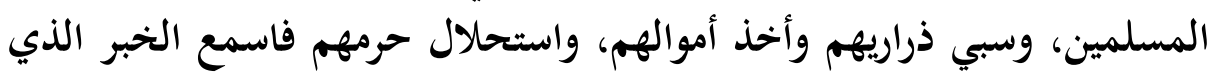

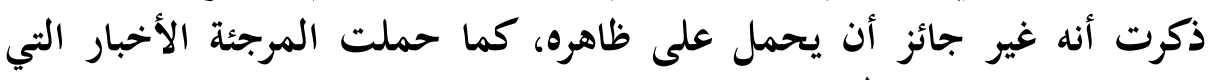
ذكرناها على ظاهرها)

\section{ومن خحلال ما سبق يتبن}

أن المرجئة عندما تمسكوا بقولمم بأن المؤمن لا تضره المعصية وحينئذ لما كانت الشفاعة

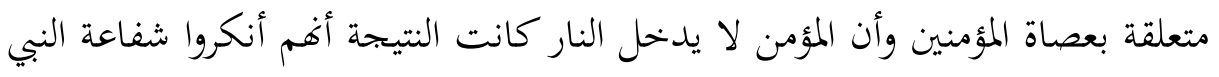

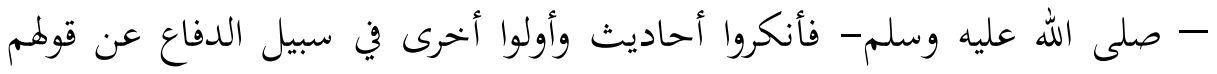
وهذا مع كونه يؤثر على عقيدة الإنسان إلا أنه له جانب أخلاقي سيء وأبئ أبينه الآن .

$$
\text { ا - كتاب التوحيد لابن خزيمة ( جـ / صـ 01/). }
$$




\section{إنكار الشفاعة وعلاقته بالأخلاق \\ إن القول بإنكار الشفاعة له تأثيره السلبي على الأخلاق للألأسباب الأتيه:-}

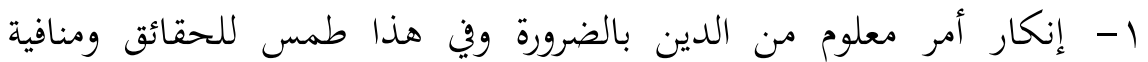

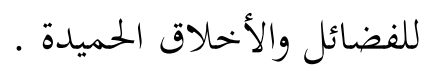

r- التشويش والتشكيك في أمور الدين، والكتب المتبدة المعتمدة المتواتر صحتها

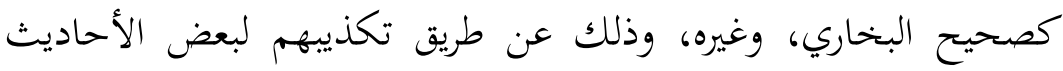

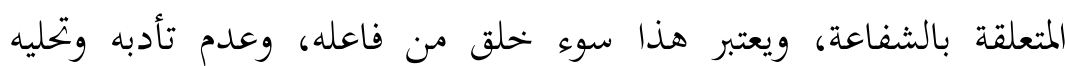

$$
\text { بالأخلاق الإسلامية . الماعة، ويعتر }
$$

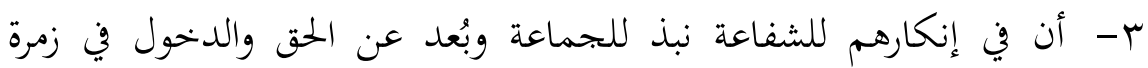

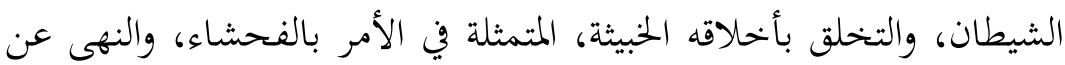

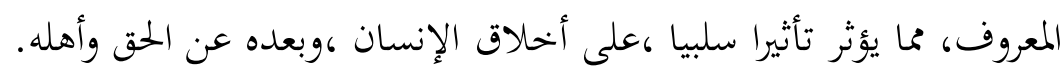

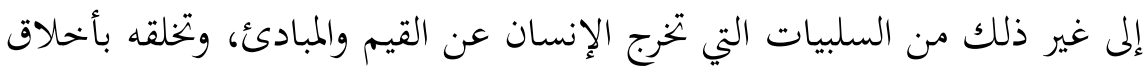

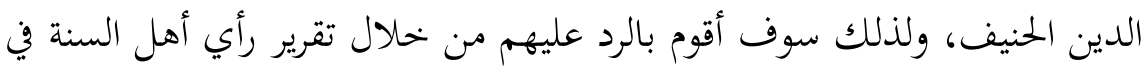

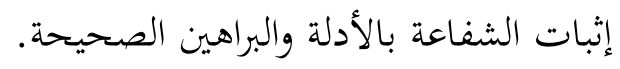

\section{الرد على المرجئة في إنكارهم للشنفاعة .}

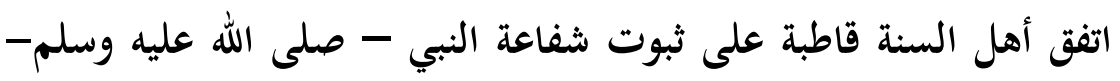

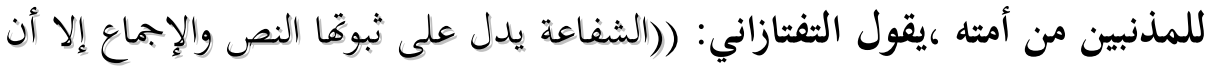

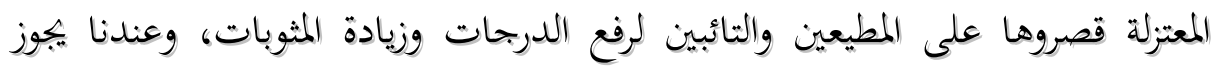

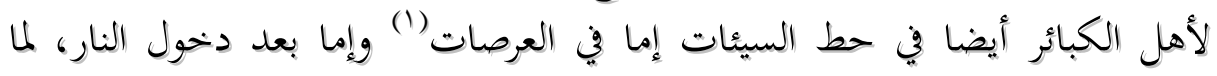

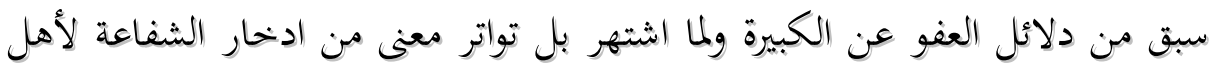

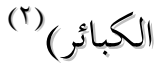

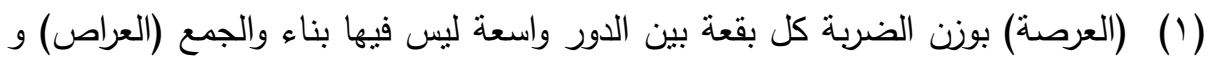

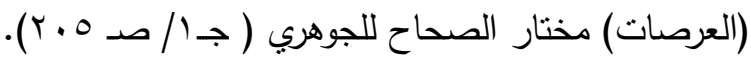

$$
\begin{aligned}
& \text { (Y) شرح الدقاصد اللتفتازاني ( جـ/ صـ (101). }
\end{aligned}
$$


ومن الأدلة على هذا

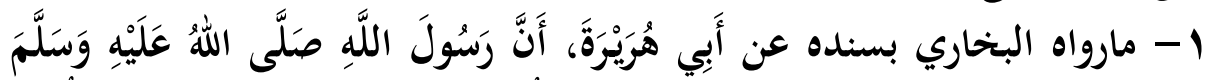

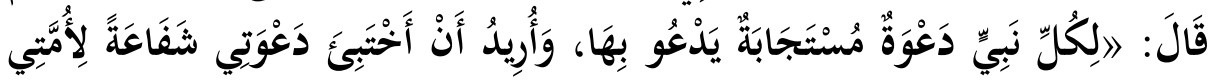

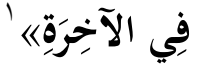

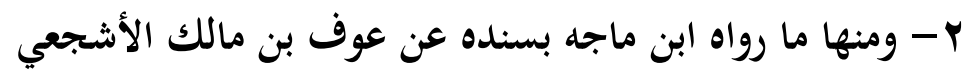

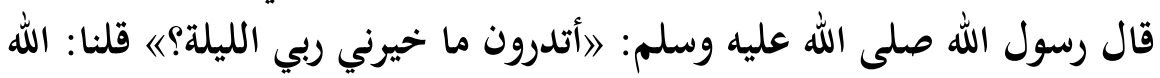

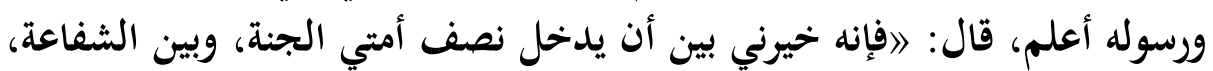

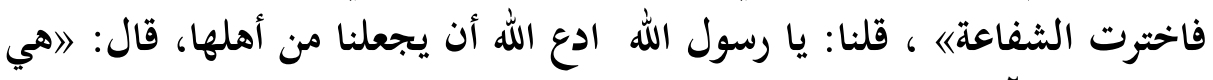

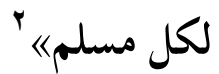

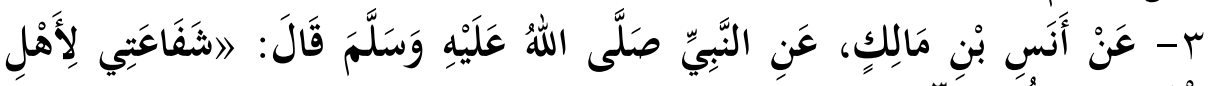

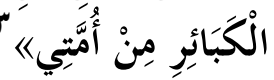

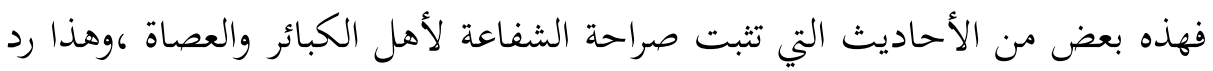

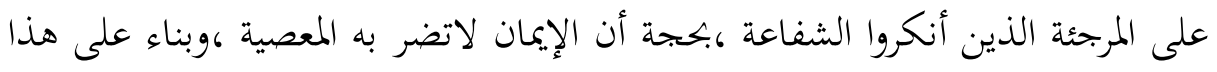

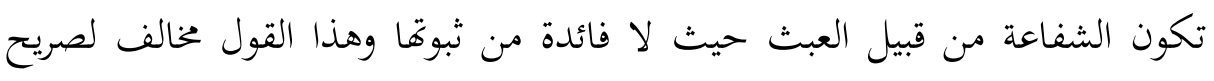
المنقول ،وصحيح المعقول.

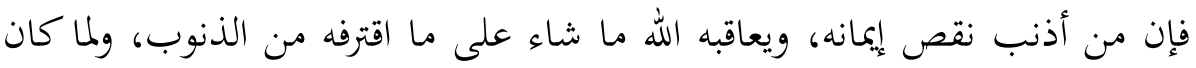

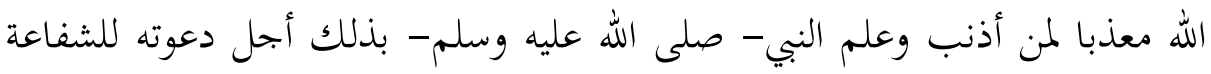
للعصاة يوم القيامة.

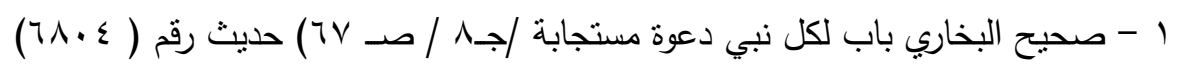

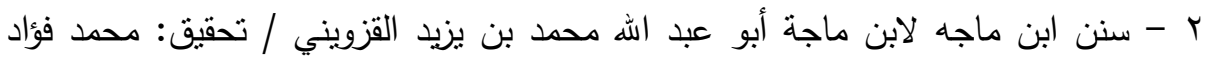

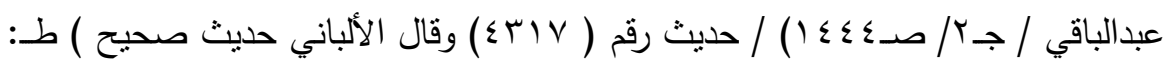

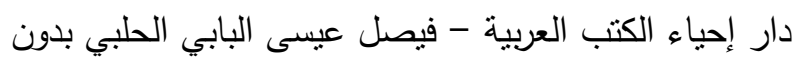

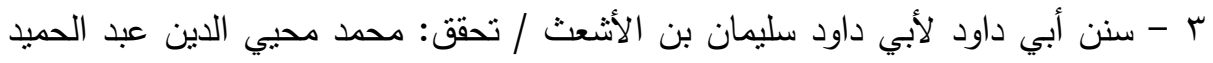

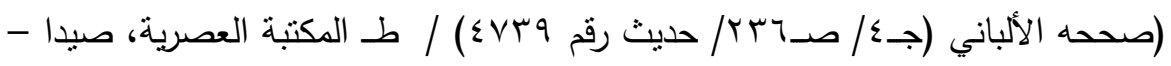




\section{أهم النتائج}

أهم النتائج التي توصلت إليها من خهلال عمل البحث ومعايشتي له

$$
-: \text { وهى }
$$

1- أن القول بالإرجاء في بداية نشأته كان علامة على إخحلاص قائلة

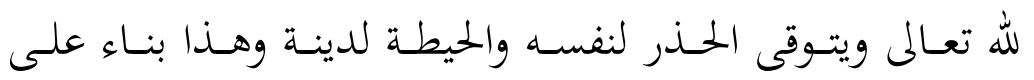

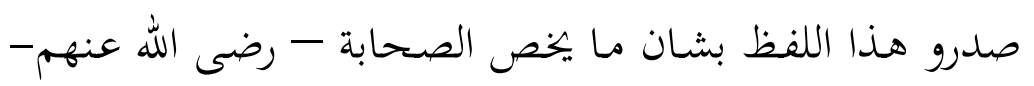

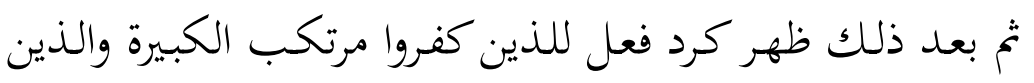
قالوا بأنه في منزلة بين المنزلتين . r- أصبح القول بالإرجاء بعد ذلك فرقة لها مبادئها ،وأصولها العقدية

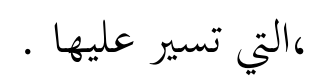

r- الدارس لهذه الفرقة تقابله مشكلة ذات أهمية تتمثل في عدم وجود

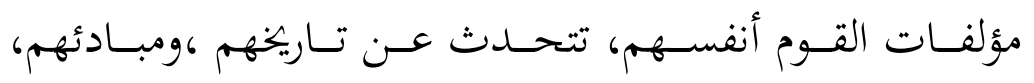

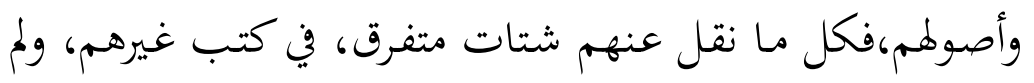
يوجد مؤلف واحد أصيل ،نستقي منه أصولمه.

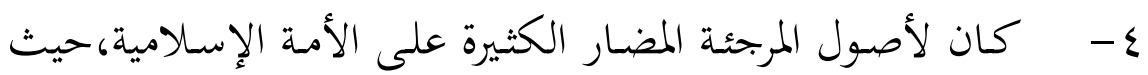

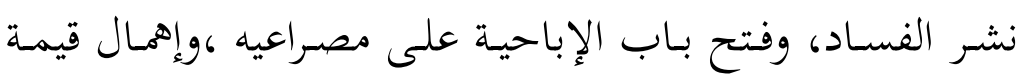

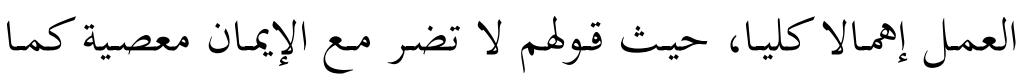
تنفع مع الكفر طاعة.

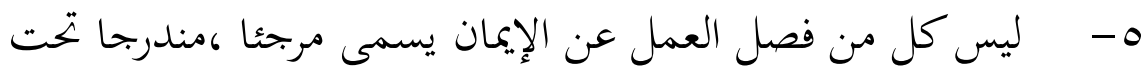

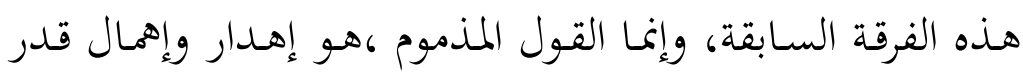

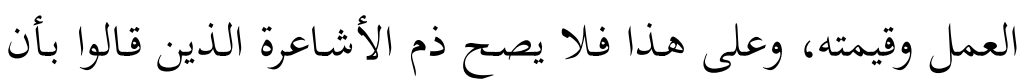

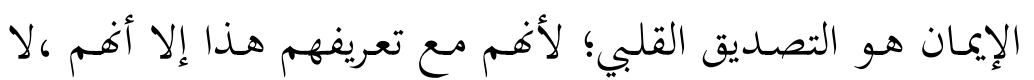
ينكرون قيمة العمل ،بل جعلوه من شروط الإيمان. 
7- أن فرقة المرجئة انتهجت منهجا غير صحيح عندما قالوا قولهم

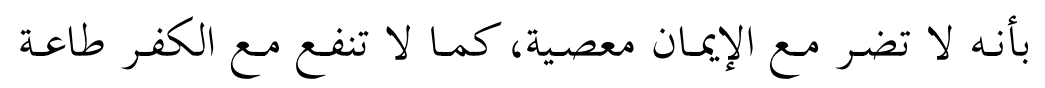

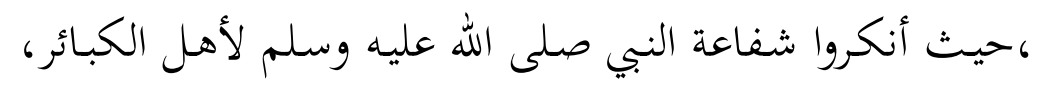

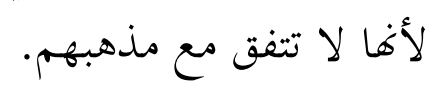

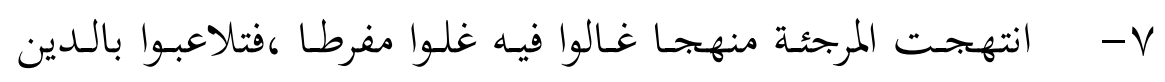

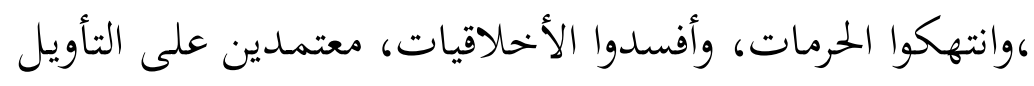

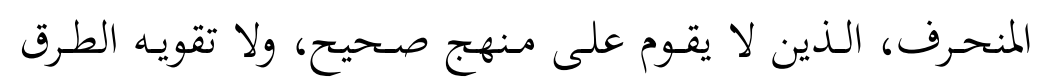

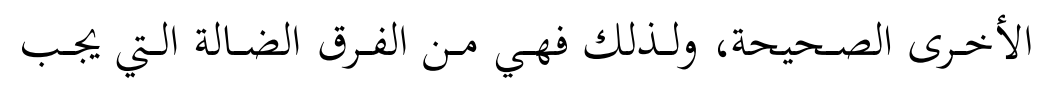

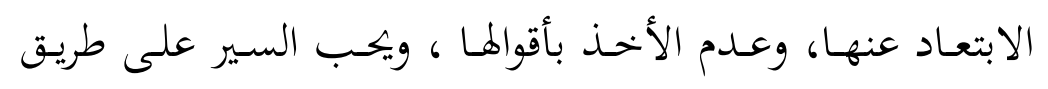

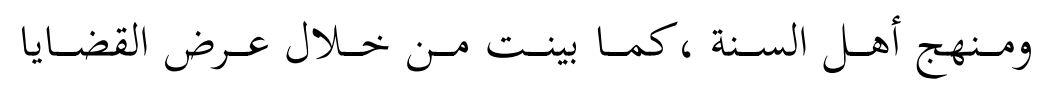

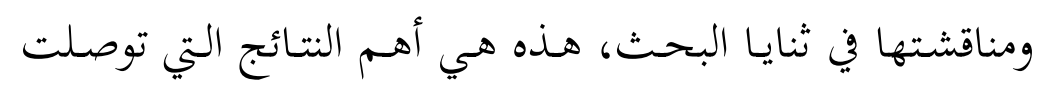
إليها من خحلال معايشتي لهذا البحث والله ولي التوفيق. 


\section{المصادروالمراجع}

ا ــ لسـان العرب / لمحمد بن مكرم بن على، أبو الفضل، جمـال الدين ابن

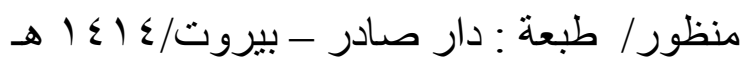

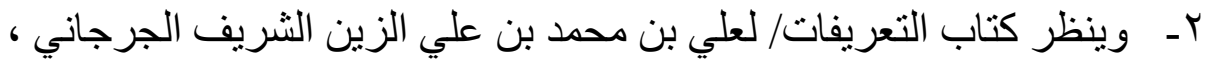

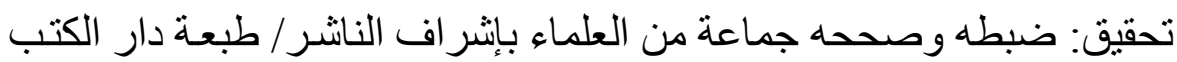

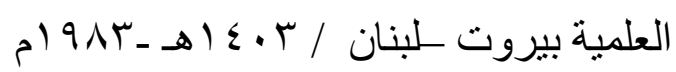

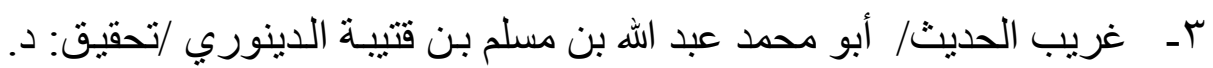

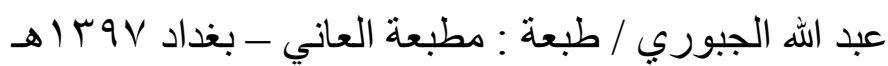

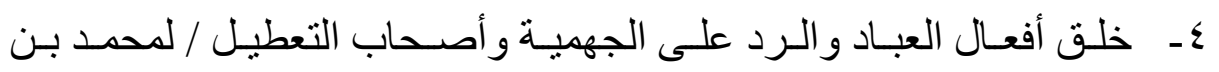

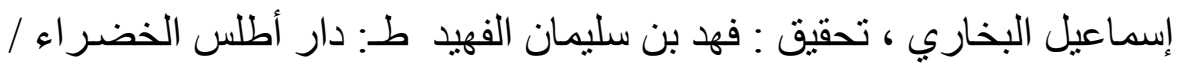

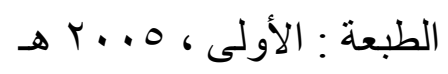

0ـ الملل و النحل للثهرستاني / تحقيق أ.د علي عبد الباسط مزيد /صــ 1 / طـ

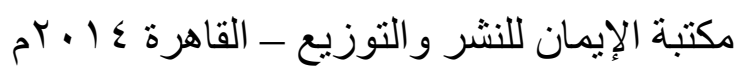

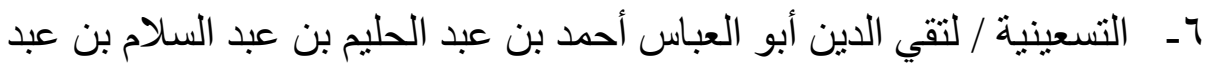

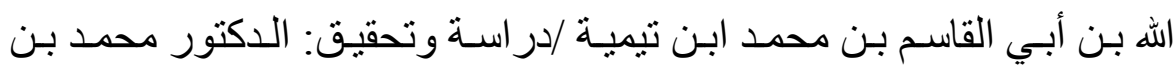

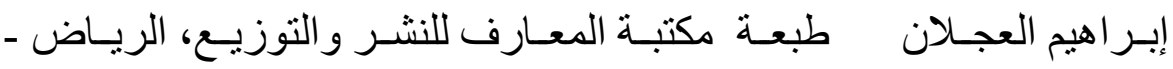

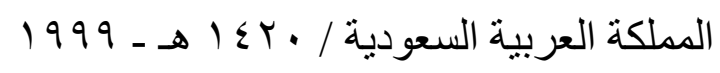

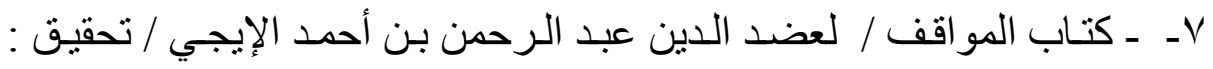

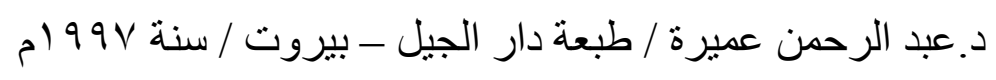

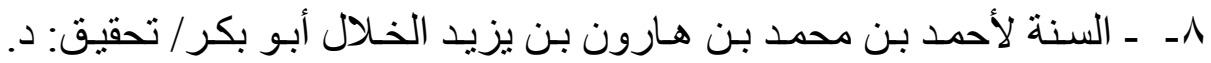

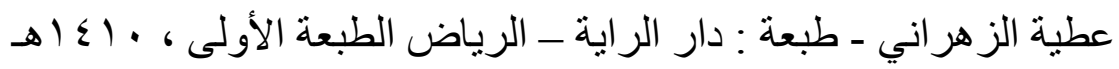

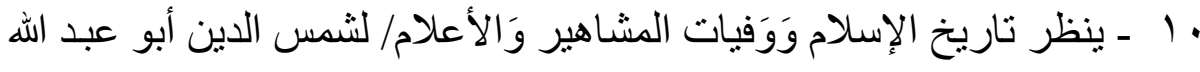

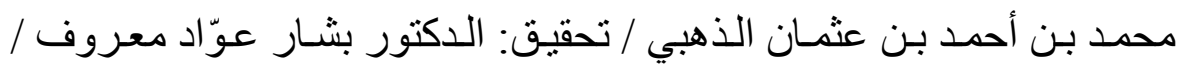

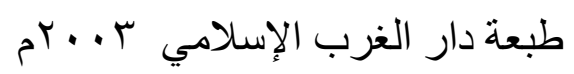




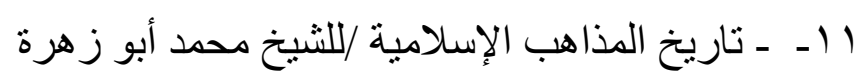

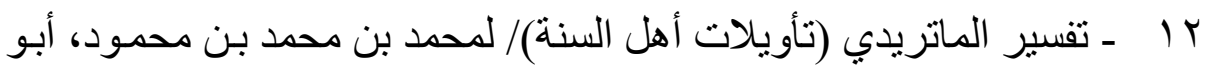

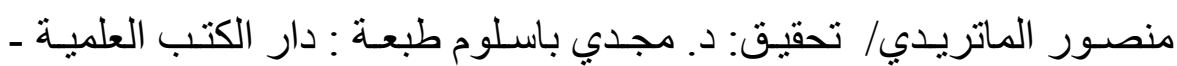

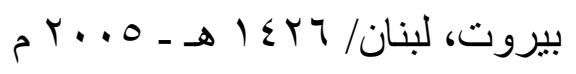

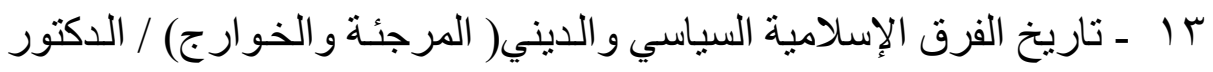

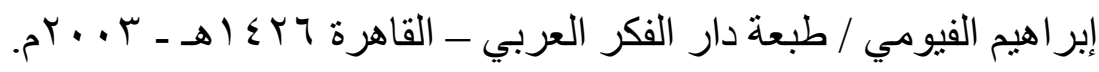

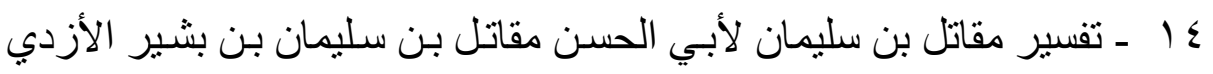

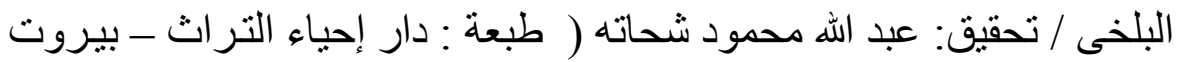

ه $1 \leqslant r r$

10 ـ النبوات / لابن تيمة المطبعة السلفية ـ القاهرة، 11 أهـ.

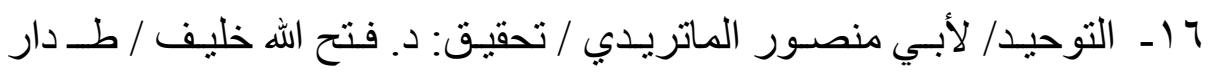

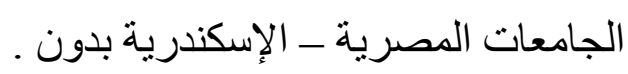

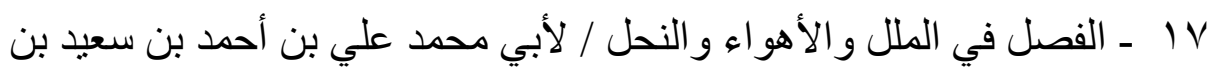
حزم الأندلسي القرطبي الظاهري / : مكتبة الخانجي - القاهرة بدون. 11 ـ مجموع الفتاوى/ لإبن تيمية / تحقيق : عبد الرحمن بن محمد بن قاسم الطبعة : مجمع الملك فهذ لطباعة المصحف الثريف، المدينة النبوية، المملكة الثنة

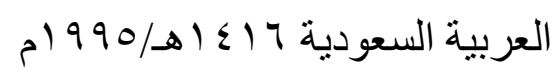

19 ـ ـينظر ظـاهرة الإرجـاء في الفكر الإسـلامي د / سفر بـن عبد الرحمن

$$
\text { الحوالي }
$$

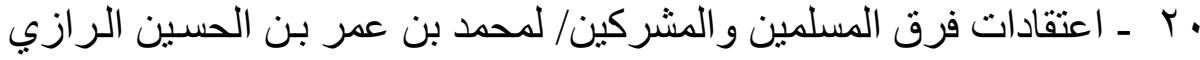

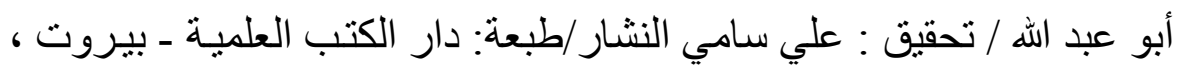


آ آ حلية الأولياء وطبقات الأصفياء/ لأبي نعيم أحمد بن عبد الله بن أحمد بن

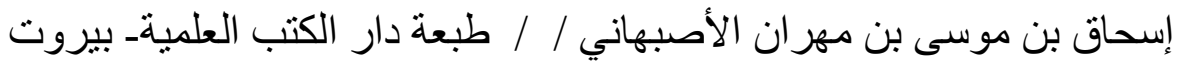

9

r r - تفسير الثوري/ لأبي عبد الله سفيان بن سعيد بن مسروق الثوري الكوفي

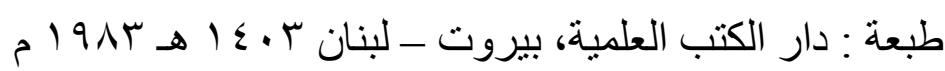

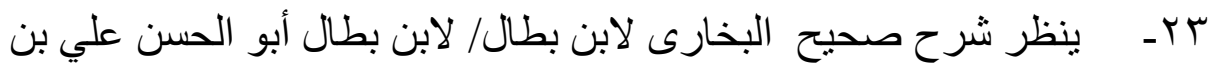

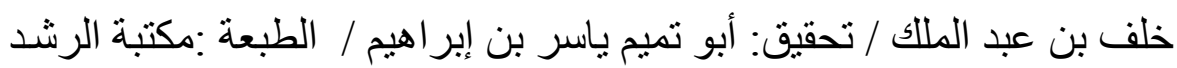

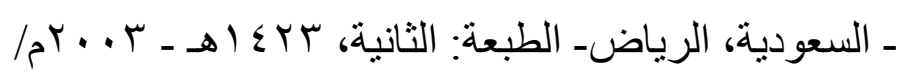

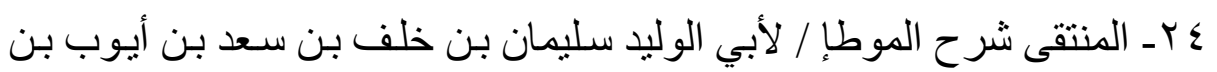

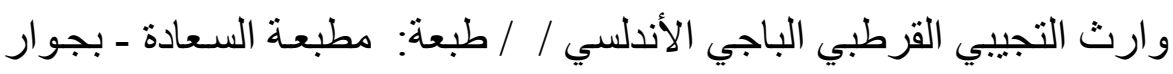

محافظة مصر ب كس اهـ

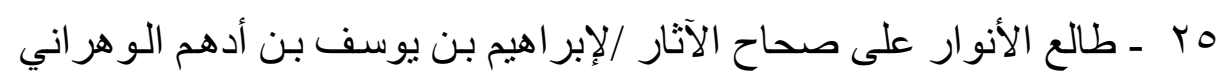

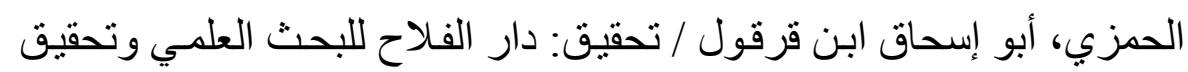

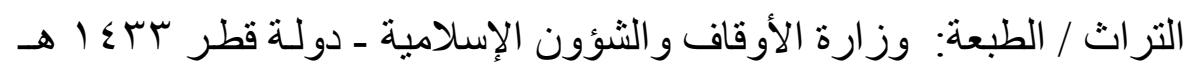

$$
\text { r. Ir - }
$$

جr ـ الفرق بين الفرق وبيان الفرقة الناجيـة / لعبد القاهر البغدادي / / طـ دار

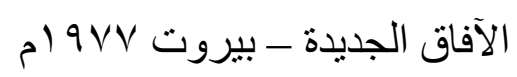

TV

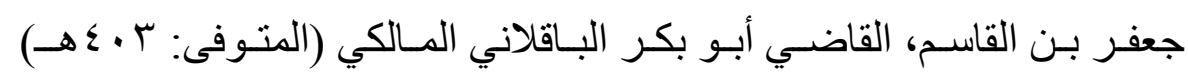

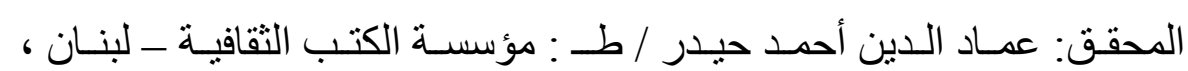

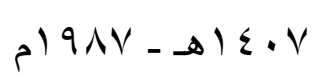

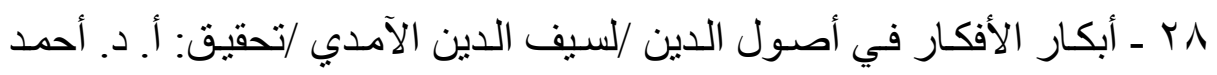

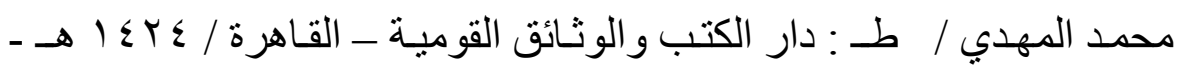

$$
\text { r. }
$$




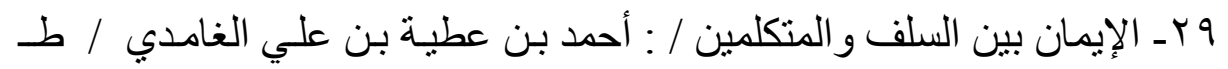

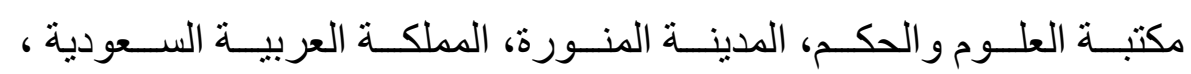

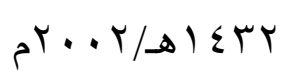

• r ـ شرح ثلاثة الأصول /لمحمد بن صالح بن محمد العثيمين / ط: دار الثريا

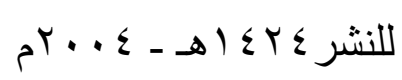

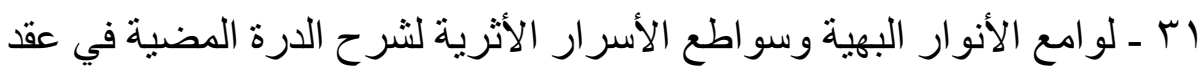

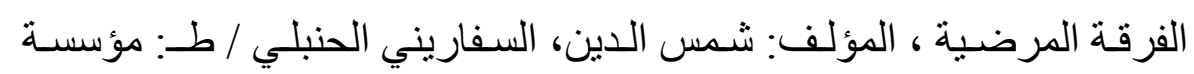

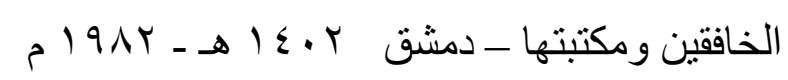

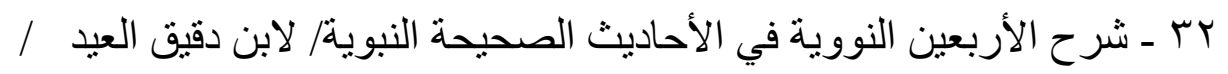

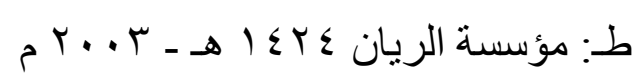

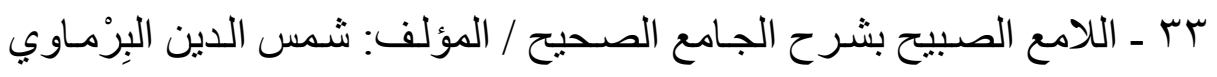

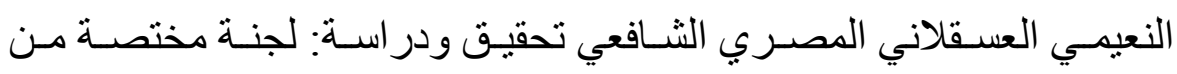

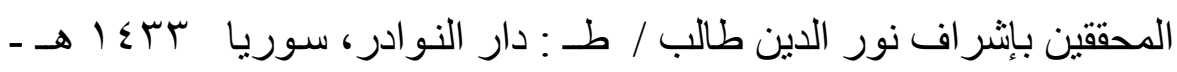

$$
\text { retrtr }
$$

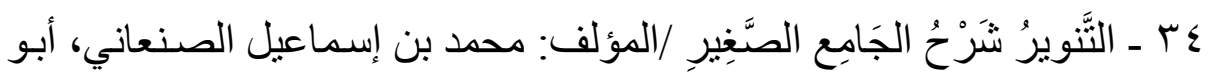

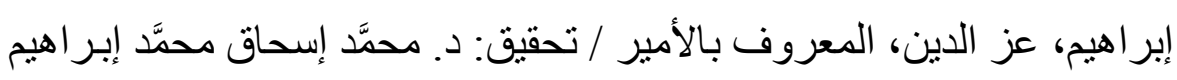

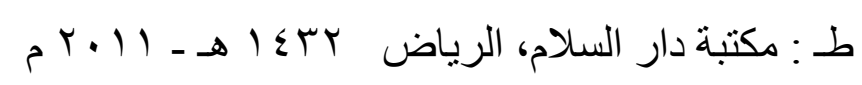

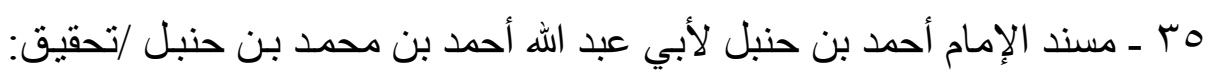

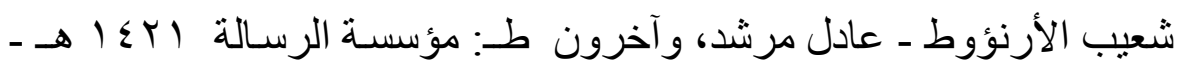

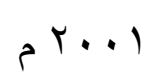

جr ـ الجانب الإيمـاني و الأخلاقي في الإسـلام تـأليف أستاذنا أد / محمد عبد

$$
\text { الفضيل عبد العزيز القوصي }
$$




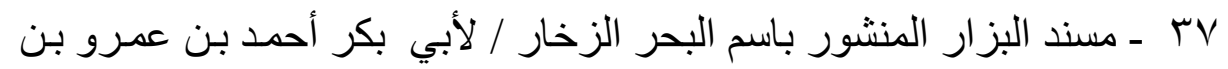

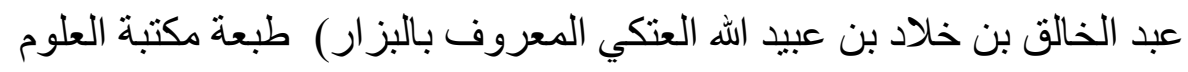

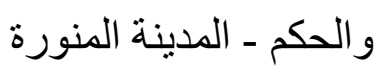

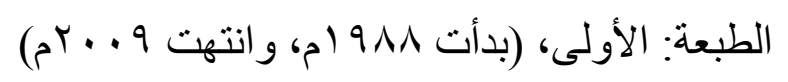

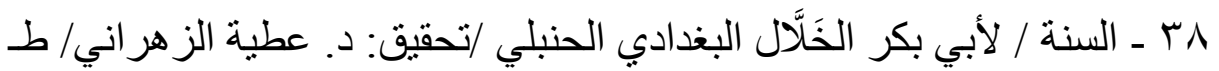

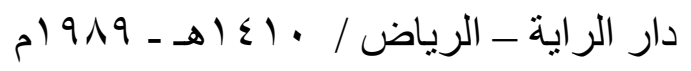

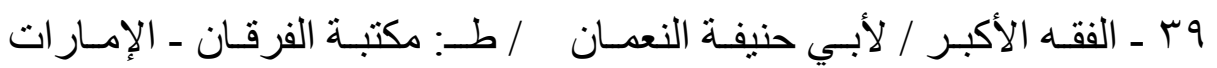

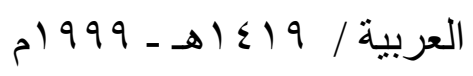

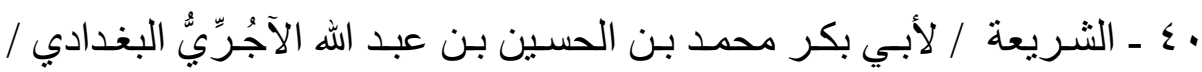

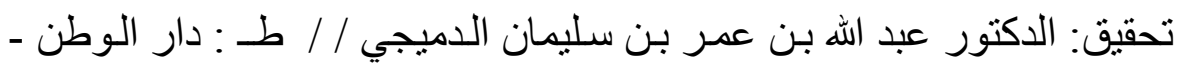

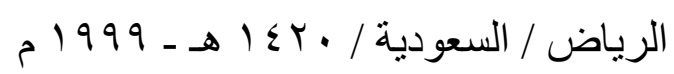

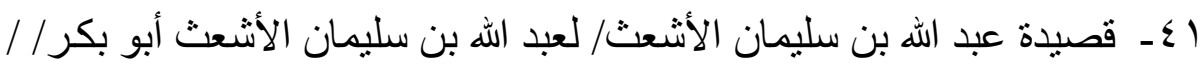

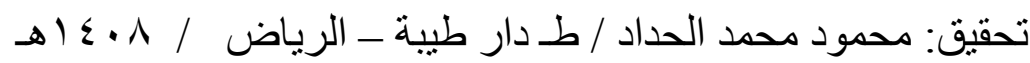

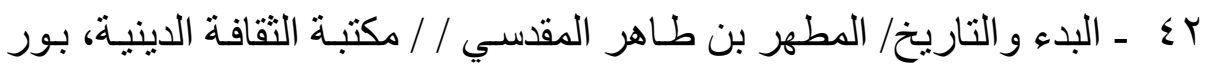
سعيد بذون

rـ ـ تاريخ مختصر الدول/ لأبي الفرج المعروف بابن العبري / تحقيق: أنطون

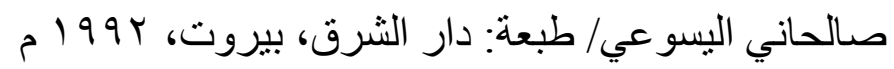

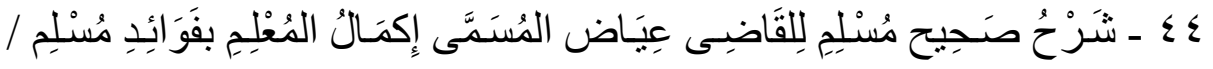
للمؤلف / عياض بن موسى بن عياض بن عمرون اليحصبي السبتي، أبو

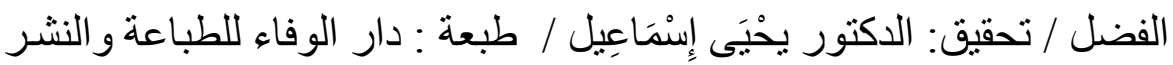

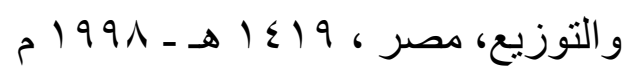

0ـ ـ السنة / لأبي عبد الرحمن عبد الله بن أحمد بن محمد بن حنبل / المحقق: د. د.

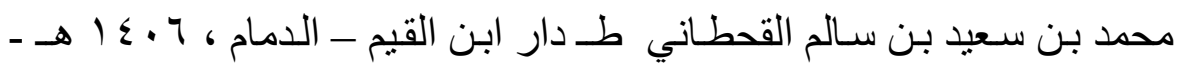




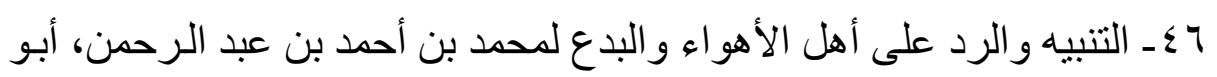

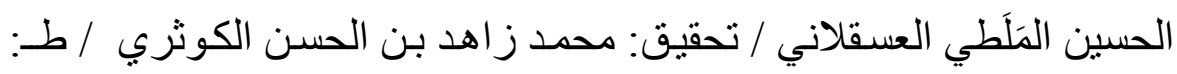

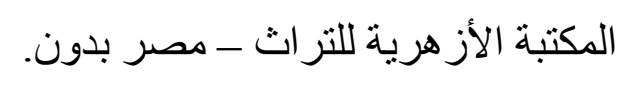

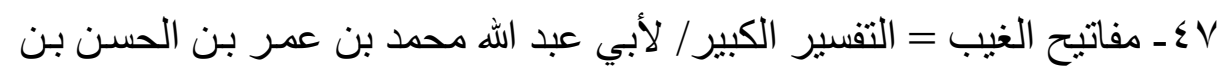

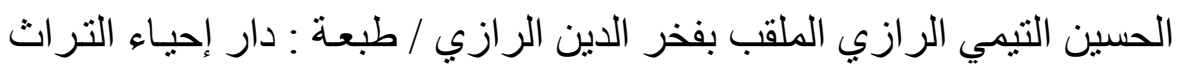

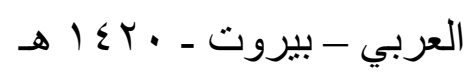

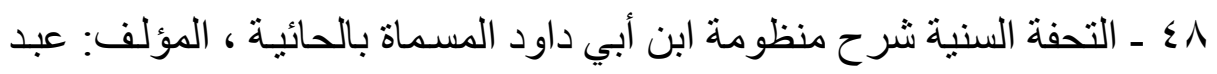

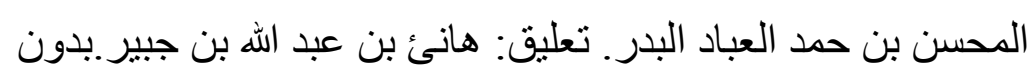

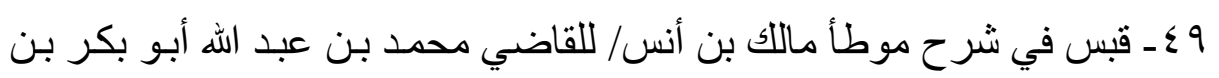

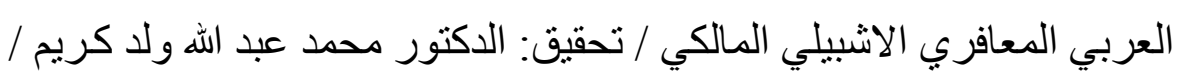

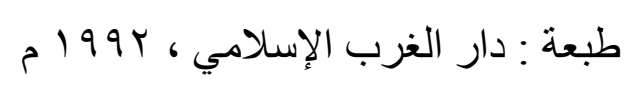

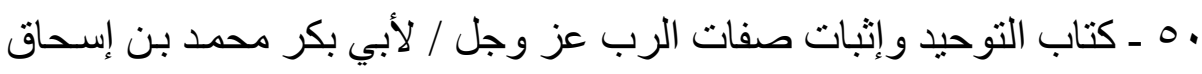

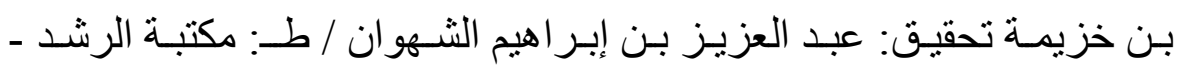

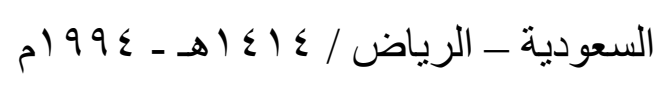

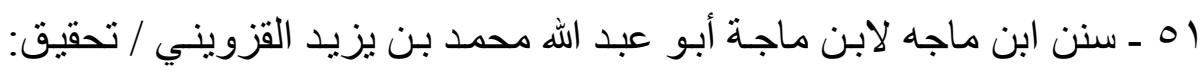

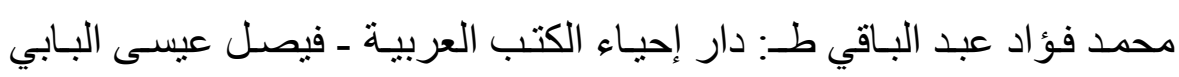

$$
\text { الحلبي بدون }
$$

O O ـ سنن أبي داود لأبي داود سليمان بن الأشعث / تحقق: محمد محيي الدين

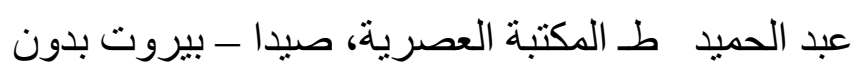

